\title{
A Legal Critique of the Award of the Arbitral Tribunal in the Matter of the South China Sea Arbitration
}

\author{
National Institute for South China Sea Studies*
}

This critique assesses each of the dispositive findings on jurisdiction and merits in the Award of South China Sea Arbitration, ${ }^{1}$ from the perspective of the applicable substantive and procedural rules of public international law. This critique does not address in detail the Arbitral Tribunal's Award on Jurisdiction and admissibility, ${ }^{2}$ dated 29 October 2015. However, it refers to the Award on Jurisdiction where relevant for the purposes of our legal critique of the Award. The core conclusions in respect of the Award are summarised below. In short, our analysis indicates that there are substantial grounds to question the validity of most of the Tribunal's central findings of jurisdiction and merits in the Award.

The core conclusions in respect of the Award are as follows: First, the Tribunal's finding that it had jurisdiction over the Philippines' Submission nos. 1 and 2 is open to substantial doubt. The principal issues at stake in establishing China's maritime entitlements in the South China Sea are inextricably linked to questions of territorial title over land and maritime areas in the South China Sea - issues that are clearly excluded from compulsory international dispute settlement under UnCLOS. The Tribunal's assessment of China's historic claims in the South China Sea, within the "nine dash line", and its conclusion that those claims did not include claims to "historic titles" so as to preclude

* This research project has been undertaken by the National Institute for South China Sea Studies (NISCSS). NISCSS has specialized in research on issues concerning the South China Sea for more than 25 years. This is an independent article and is published for public dissemination. A research team was formed in this regard under the direction of Dr. Shicun Wu, President of Niscss and was composed of international law scholars, lawyers, historians and technical experts from the United Kingdom, the Netherlands, the United States and China. NISCSS would like to express its gratitude to each team member for their efforts and contributions, and in particular to FIETTA LLP for its invaluable assistance on this project.

1 The South China Sea Arbitration (Phil. v. China), Case No. 2013-19, Award (Perm. Ct. Arb. 2016) [hereinafter Award].

2 The South China Sea Arbitration (Phil. v. China), Case No. 2013-19, Award on Jurisdiction and Admissibility (Perm. Ct. Arb. 2015) [hereinafter Award on Jurisdiction and Admissibility]. 
jurisdiction under Article 298 of the Convention, are also highly questionable. The Tribunal's sharp distinction between "historic titles" and "historic rights", and its observation that only the former can be excluded from dispute settlement procedures by way of declaration under Article 298 under UNCLOS, has no clear basis in international law. Even if the Tribunal was correct in its finding that "historic titles" for the purposes of Article 298 form only a small subset of "historic rights", the Tribunal had abundant evidence before it that China does claim "historic titles", in the form of claims to sovereignty, within the "nine dash line". Yet another doubt arises from whether the Tribunal was competent to determine that China's nine dash line and related historic rights, as well as being "contrary to the Convention", were "without lawful effect" for the purposes of Submission no. 2. Arguably, such a question does not concern "the interpretation or application of [UNCLOS]", and thus falls beyond the jurisdiction of an UNCLOS arbitral tribunal.

Second, the Tribunal's findings on the merits of the Philippines' Submission nos. 1 and 2 are also subject to substantial doubt. In particular, the Tribunal's critical conclusion that UNCLOS "leaves no space for an assertion of historic rights" is highly questionable. Historic rights can and do continue to exist alongside (and independent from) UNCLOS, as confirmed by the award in the Eritrea/Yemen case and even in some UnCLOS articles (such as Article 51(1) on "traditional fishing rights" in archipelagic waters). Therefore, the Tribunal's conclusion that "the Convention superseded any historic rights or other sovereign rights or jurisdiction in excess of the limits imposed therein" is likely wrong. This conclusion was central to the Tribunal's substantive findings with respect to the Philippines' Submission nos. 1 and 2. It was therefore probably improper for the Tribunal to discard the "nine dash line", and the rights to which it refers, on the basis that UNCLOS "supersedes" all historic rights. Rather, historic rights regimes in maritime areas, including the EEZ, are capable of being preserved in international law notwithstanding UNCLOS.

Third, the Tribunal's findings with respect to the legal status of the features in the South China Sea (Philippines Submission nos. 3 to 7 ) are highly questionable in a number of respects. The Tribunal's conclusion that Itu Aba and all of the other high-tide features in the Spratly Islands constitute "rocks", which cannot sustain human habitation or economic life of their own in the sense of Article 121(3), is open to challenge both as a matter of law and as a matter of evidence. From a legal perspective, the Tribunal interpreted Article 121(3) in a highly restrictive way that contradicts both the Vienna Convention on the Law of Treaties ("VCLT") and State practice. On the evidence before it the Tribunal could easily have concluded that both Itu Aba on its own and (a fortiori) the Spratly Islands as a whole are capable of sustaining human habitation for 
the purposes of Article 121(3). It could also (separately) have concluded that both Itu Aba on its own and (a fortiori) the Spratly Islands as a whole are capable of sustaining economic life of their own for the purposes of Article 121(2) and (3). Either finding would have been sufficient to deprive the Tribunal of jurisdiction in respect of Philippines Submission nos. 5, 8, 9 and 12, and from making a number of its substantive findings on the merits (particularly dispositif nos. 7, 8, 9, 10, 14 and $16($ a) and (d)).

Fourth, on the evidence before it, the Tribunal could equally have concluded that Mischief Reef is a high tide feature and is thus capable of appropriation and entitled at least to a territorial sea under UNCLOS for the purposes of Article 121(3). Had the Tribunal reached this conclusion, it would have had no jurisdiction in respect of Philippines Submission nos. 5, 8, 9, 12 (so far as they concerned Mischief Reef and its territorial sea), and would thus have been unable to reach a number of its substantive findings on the merits (particularly dispositif nos. 7, 10, 14 and 16(a) and (d), as they relate to Mischief Reef).

Fifth, the Tribunal's decision not to analyse in the Award the legal status under Article 121 of a number of other high tide features (namely, Amboyna Cay, Flat Island, Loaita Island, Namyit Island, Nanshan Island, Sand Cay, Sin Cowe Island and Swallow Reef) is surprising. By taking such a "shortcut", the Tribunal arguably violated its obligation under Article 9 of Annex VII to UNCLOS to confirm its own jurisdiction. In order to do so, the Tribunal had to assess, in a meaningful way and with reference to available evidence, the status of all of the high tide features in the Spratly Islands.

Sixth, as regards a number of the Philippines' claims concerning Chinese activities in the South China Sea (Philippines Submission nos. 8 to 13), the Tribunal probably lacked jurisdiction. In particular, it probably lacked jurisdiction over Submission nos. 8, 9 and 12, due to the conclusions summarised above. In addition, the Tribunal arguably erred in concluding that the "military exception" at Article 298(1)(b) of UNCLOS was inapplicable, and thus in taking jurisdiction over the Philippines' Submission nos. 11 and 12 (b).

Seventh, to the extent that it did have jurisdiction over the Philippines' claims concerning Chinese activities in the South China Sea (Philippines Submission nos. 8 to 13), while a number of the Tribunal's specific merits findings are probably correct on the law (for example, as regards the nature and extent of States' environmental and due diligence obligations under UNCLOS), many of those findings related to isolated incidents or were based on limited evidence. Further, the Tribunal's conclusion that China's operation of its law enforcement vessels near Scarborough Shoal violated COLREgS and, as a consequence, Article 94 of UnClos (Philippines Submission no. 13) appears incorrect because Article 94 does not apply to territorial sea areas. 
Eighth, in a number of respects, the Tribunal arguably violated its responsibility under Article 9 of Annex VII to satisfy itself that the Philippines claims were "well founded in fact and law". For example, in respect of the Philippines' Submission nos. 4 and 6, the Tribunal engaged archivists in order to seek out evidence that was ultimately relied upon in order to uphold the Philippines' claims against China. In parallel, the Tribunal failed to explore evidence that may have been readily available to it and that may have undermined the Philippines' claims (such as evidence held by Taiwan in respect of Itu Aba). In doing so, the Tribunal arguably exceeded its mandate by relieving the Philippines of its burden of proof.

Ninth, the Tribunal committed a further procedural error by failing to provide the Parties with an opportunity to cross-examine four experts that it appointed after the merits hearing, and upon whose advice it relied in the Award.

Tenth, the Tribunal misapplied the Monetary Gold principle with respect to third State rights and interests in finding that the "legal interests of Malaysia do not form 'the very subject-matter of the dispute' and are not implicated by the Tribunal's conclusions". Clearly, the Tribunal's findings that a number of high tide features claimed by Malaysia constitute "rocks" for the purposes of Article 121(3) of UNCLOS implicated Malaysia's legal interests. They also implicated Vietnam's legal interests. This provides another basis to question the Tribunal's jurisdiction with respect to its critical findings as to the legal status of the Spratly Islands under UNCLOS.

Following this Introduction and Overview, Section 2 below analyses the Tribunal's findings with respect to China's maritime entitlements and claims in the South China Sea, including as regards "historic rights" and the "nine dash line", as addressed at Chapter $\mathrm{v}$ of the Award. Section 3 analyses the Tribunal's findings on the legal status of islands and other features in the South China Sea, as addressed at Chapter vi of the Award. Section 4 analyses the Tribunal's findings with respect to Chinese activities in the South China Sea, as addressed at Chapter VII of the Award. Finally, Section 5 examines certain procedural and evidentiary issues arising from the Tribunal's handling of the merits phase of the Arbitration, including as regards the important issues of the Philippines' burden of proof and the rights and interests of third States. Annex 1 sets out two tables comparing the characteristics of Itu Aba and a number of small features around the world claimed (or accepted) as fully-entitled islands, against the five criteria identified by the Tribunal for such status under Article 121(2) of UNCLOS. 
2

\section{The Tribunal's Findings with Respect to China's Maritime Entitlements, China's Claims to Sovereign Rights Jurisdiction and "Historic Rights" and the "Nine Dash Line" (Philippines Submission Nos. 1 and 2; Award Chapter V)}

The Philippines' Submission nos. 1 and 2 read: ${ }^{3}$

(1) China's maritime entitlements in the South China Sea, like those of the Philippines, may not extend beyond those expressly permitted by the United Nations Convention on the Law of the Sea ('UNCLOS' or the 'Convention').

(2) China's claims to sovereign rights jurisdiction, and to 'historic rights' with respect to the maritime areas of the South China Sea encompassed by the so-called 'nine dash line' are contrary to the Convention and without lawful effect to the extent that they exceed the geographic and substantive limits of China's maritime entitlements expressly permitted by UNCLOS. This Commentary on Part v of the Award of 12 July 2016 consists of four further sections. Section A discusses the determination of the Tribunal that it had jurisdiction to consider Submission nos. 1 and 2. Section 2.1 provides a commentary on the findings of the Tribunal with respect to Submission no. 1 and Section 2.2 does so with respect to Submission no. 2. Section 2.3 summarises the general and more specific conclusions on Chapter $\mathrm{v}$ of the Award.

The Tribunal's Jurisdiction in Respect of Submission Nos. 1 and 2

2.1.1 Award on Jurisdiction and Admissibility dated 29 October 2015

In its Award on Jurisdiction and Admissibility, rendered on 29 October 2015, the Tribunal stated that Submission nos. 1 and 2 concerned neither a dispute over territorial sovereignty over any land features within the South China Sea nor a dispute over maritime boundary delimitation. Rather, they reflected a dispute concerning the source of China's maritime entitlements in the South China Sea and the interaction of China's claimed historic rights with the provisions of the Convention. Therefore, in the view of the Tribunal, this was unequivocally a dispute concerning the interpretation and application of the Convention.

Nonetheless, the Tribunal suspended its final determination on jurisdiction over Submission nos. 1 and 2 to the merits stage of the proceeding. This is because a finding of jurisdiction was dependent on the Tribunal's substantive findings on the nature of any historic rights claimed by China, and thus

3 Award, supra note 1, at para. 112. An earlier formulation of these submissions appears in The South China Sea Arbitration (Phil. v. China), Case No. 2013-19, Memorial of the Philippines (30 March 2014), Vol. I, at 271 [hereinafter Memorial of the Philippines]. 
on whether the dispute was covered by the exclusion from jurisdiction in Article 298 of the Convention for disputes concerning "historic bays or titles".

In response to the Award on Jurisdiction and Admissibility, China took once again the view that the Tribunal lacked jurisdiction because "the essence of this arbitration case is territorial sovereignty and maritime delimitation and related matters." ${ }^{5}$

\subsubsection{Final Award Dated 12 July 2016}

In its final Award of 12 July 2016, the Tribunal therefore returned to address issues of jurisdiction and admissibility. It decided that it had jurisdiction to consider the matters raised in Submission nos. 1 and 2 and that the claims contained therein were admissible. ${ }^{6}$ In doing so, the Tribunal related China's claims to maritime entitlements in the relevant areas of the South China Sea as claims to "historic rights" to the exclusive use of the living and nonliving resources. Furthermore, the Tribunal also found that such "historic rights" cannot be equated with the concept of "historic titles" as it appears in the jurisdiction exemption clause of Article 298(1)(a)(i) of UNCLOs. Lastly, the Tribunal ruled that China's claims to maritime entitlements in the South China Sea can only be judged upon the basis of the principles and rules contained in UNCLOS. ${ }^{7}$ All of these findings were essential to the Tribunal's conclusion that it had jurisdiction over Submission nos. 1 and 2.

As an overarching observation, it is difficult to disentangle the determination of China's maritime rights and entitlements in the South China Sea from the broader issue of the territorial sovereignty over the islands and maritime areas in the South China Sea. The principal issues at stake in establishing China's maritime entitlements in the South China Sea are inextricably linked to the general issue of the territorial title over the land and the maritime areas in the South China Sea - issues that are clearly excluded from compulsory international dispute settlement under UNCLOS. ${ }^{8}$ On this basis alone, it is

4 Award on Jurisdiction and Admissibility, supra note 2, at paras. 398-99.

5 China, Statement of the Ministry of Foreign Affairs of the PRC on the Award on Jurisdiction and Admissibility of the South China Sea Arbitration by the Arbitral Tribunal Established at the Request of the Philippines, 30 October 2015, on the Ministry of Foreign Affairs of China website at www.fmprc.gov.cn/mfa_eng/zxxx_662805/t1310474.shtml.

6 Award, supra note 1 , at paras. $276-78$.

7 Id. at para. 278 .

8 In a 1990 Article, one of the Members of the Tribunal (Professor Alfred H.A. Soons) recognised the inseparability of questions of maritime delimitation and the status of features under Article 121 of unclos. See Barbara Kwiatkowska \& Alfred H.A. Soons, Entitlement to Maritime Areas of Rocks Which Cannot Sustain Human Habitation or Economic Life of Their Own, 21 Netherlands Yearbook of International LaW 139, 146, 181 (1990). 
highly questionable whether the Tribunal had jurisdiction over Submission nos. 1 and $2 .{ }^{9}$

As explained further below, the Tribunal's assessment of China's historic claims in the South China Sea, within the "nine dash line", and its conclusion that those claims did not include claims to "historic titles" so as to preclude its jurisdiction under Article 298 of the Convention, are also highly questionable.

First, the terminology of 'historic titles' and 'historic rights' cannot be so sharply distinguished such that the former can be excluded from the dispute settlement procedures by way of declaration under Article 298 under U NCLOS, while the latter cannot. Public international law does not recognise any such sharp distinction. It is unsurprising, therefore, that China has used these terms interchangeably in the past (see sub-section 2.2.1 below). The Tribunal's assessment that the optional exception to jurisdiction in Article 298(1)(a)(i) is limited to disputes relating to a narrow definition of "historical title", and thus to disputes involving claims to sovereignty over maritime areas only, is therefore subject to substantial doubt as a matter of law.

Second, even if the Tribunal were correct in its finding that "historic titles" for the purposes of Article 298 form only a small and specific subset of "historic rights" at international law, the Tribunal had abundant evidence before it that China does claim "historic titles", in the form of claims to sovereignty, within the "nine dash line". Therefore, even if the Tribunal's legal assessment was correct, its conclusion that China's claims within the "nine dash line" do not equate to claims to "historic titles" or elements of sovereignty is subject to substantial doubt as a matter of fact.

The Tribunal's basis for finding jurisdiction in respect of Submission nos. 1 and 2 generally is, therefore, tenuous. It is hard to see how the issue of the nature and scope of China's maritime rights and entitlements can be separated from the issue of Chinese claims to territorial sovereignty over the islands and maritime areas in the South China Sea. ${ }^{10}$ It is also difficult to conclude that the condition mentioned in the final part of Article 298(1)(a)(i) is met, namely that the dispute does not "... necessarily involve[s] the concurrent consideration of any unsettled dispute concerning sovereignty or other rights over continental or insular land territory shall be excluded from such submission".

Yet another serious doubt arises from whether the Tribunal was competent to determine that China's nine dash line and related historic rights, as well as being "contrary to the Convention", were "without lawful effect" for

$9 \quad$ In relation to jurisdiction dispositif no. 1.

10 See Kwiatowska \& Soons, supra note 8, at 153. 
the purposes of Submission no. $2 .{ }^{11}$ Arguably, such a question does not concern "the interpretation or application of [UNCLOs]", and thus falls beyond the jurisdiction of a Part XV UnClos tribunal. Moreover, in observing that the applicable law in the dispute was restricted to Article 293 of the Convention (in contrast to the Eritrea/Yemen arbitration), but nevertheless deciding that claims to "historic rights" within the EEZ areas were "without lawful effect" (in contrast, again, to Eritrea/Yemen), the Tribunal effectively acknowledged that, had the applicable law provision been broader as in Eritrea/Yemen, its conclusion may have been very different. Instead, the Tribunal should have declined jurisdiction over the question of whether China's claims are "without lawful effect" on the basis that Part XV and Article 293 of the Convention preclude consideration of such a question of general international law. The Tribunal's approach appears to have been based merely upon a textual construction which ignores the role of "historic rights" in general international law (as explained in the following sub-section). ${ }^{12}$

For all these reasons, it would have been more logical for the Tribunal to find a non liquet since it lacked jurisdiction to consider Submission nos. 1 and 2.

\section{The Tribunal's Conclusion that China's Maritime Entitlements} in the South China Sea May Not Extend beyond Those Expressly Permitted by uncLos (Philippines Submission No. 1; Tribunal Merits Dispositif No. 1)

This section appraises the two main elements contained in the Award regarding Submission no. 1. These are: the meaning of the notion of "historic rights", "historic bays" and "historic waters" (subsection 2.2.1) and the exclusiveness of UNCLOS in appraising the legal nature and status of China's claims (subsection 2.2.2). Subsection 2.2.3 then sets out some interim conclusions. As indicated in Section 2.3 below, the conclusions reached with respect to Submission no. 1 are also applicable to Submission no. 2.

UNCLOS itself does not employ explicitly the phrase "historic rights". It only refers to "historic bays" in Article 10(6) relating to the limits of the territorial sea and Article 298(1)(a)(i) relating to limitations and exceptions to compulsory

\footnotetext{
11 Award, supra note 1, at para. 278.

12 See on the "textual constructions" of the Tribunal, M.C.W. Pinto, Arbitration of the Philippine Claim Against China, 8(1) Asian Journal of International LaW 1, 5 (2018).
} 
procedures entailing binding decisions. The concept of "historic title" features in Article 15 and Article 298(1)(a)(i) of UnCLOS.

At paragraph 226 of the Award, the Tribunal asserted that, beyond the references to "historic titles" at Articles 15 and 298, "other "historic rights", in contrast, are nowhere mentioned in the Convention". This is incorrect. The Convention does refer to historic rights, whether explicitly by implication, in a number of contexts. For example, there is a reference to historic rights in Article 51(1) with the preservation of "traditional fishing rights" in archipelagic waters, and in Article 62(3) relating to the Exclusive Economic Zone (EEZ) where there is mention of "States whose nationals have habitually fished in the zone". In addition, some other articles include terms such as "long usage" (Article 7(5)) and "historically ... regarded" (Article 46(b)), which carry historical connotations.

All three concepts of "historic titles", "historic bays", and "historic rights" are well known in international law and have long been governed by customary international law, as partly recorded in treaty law including UNCLOS. That is not to say that the meaning of these three concepts has always been clearly defined, or that their inter-relationship has been universally understood. A well-known study on historic bays prepared by the UN Secretariat in 1957 upon request by the International Law Commission concluded that the subject of historic waters is one "where superficial agreement among practitioners conceals several controversial problems as well as some obscurity or at least lack of precision.". 3

It is widely understood that 'historic title' signifies sovereignty over land or maritime territory. As defined by Gioia in the Max Planck Encyclopaedia of Public International Law: "The term 'historic title' is [...] used to denote both the source and the evidence of a right over land or maritime territory acquired by a State through a process of historical consolidation". ${ }^{14}$

It follows from the ICJ judgment in Continental Shelf (Tunisia/Libya) that historic title can relate to sovereignty over a wider belt of territorial sea as well as special sovereign rights falling short of full territorial sovereignty beyond the territorial sea. ${ }^{15}$ The latter may include historic fishing rights, like in the case of

13 Historic Bays: Memorandum by the Secretariat of the United Nations, at 6, U.N. Doc. A/ CONF.13/1 (30 September 1957). Since the concept of historic bays is not of direct relevance to the South China Sea dispute, comments will be provided below on historical titles and historical rights only.

14 Andrea Gioia, Historic Titles, Max Planck Encyclopedia of Public International LAW (May 2013, online version), at para. 1.

15 Case concerning the Continental Shelf (Tunisia v. Libya), 1982 I.C.J. Rep. 18 (Feb. 24) (Judgment). In this case it concerned Tunisia's alleged zone of long-established fishing activities. 
Eritrea $v$. Yemen which concerned traditional or artisanal fishing rights enjoyed for centuries, ${ }^{16}$ or in Qatarv. Bahrain regarding Bahrain's claims to historic fishing rights over the exploitation of pearling banks (which were unsuccessful on the evidence). ${ }^{17}$ Gioia also states that in order to be relevant such historic rights must amount to exclusive rights acquired by a State on the basis of a claim made à titre de souverain. ${ }^{18}$

According to the ICJ, the acquisition of sovereign rights falling short of full territorial sovereignty in another State's territory or on the high seas could follow "on the basis of long practice" between two or more States "accepted by them as regulating their relations", ${ }^{19}$ for example a long custom. It should be noted that the Tribunal limits the concept of historic title to "[being] used specifically to refer to historic sovereignty to land or maritime areas", ${ }^{20}$ thus excluding more limited rights falling short of sovereignty. These would then all come within the scope of the more generic concept of "historic rights".

"Historic waters" are based upon historical title. In the words of the Tribunal, " [h] istoric waters' is simply a term for historic title over maritime areas". ${ }^{21}$ This also means that, in its view, historic waters are bound to be part of the sovereign territory of a State and that sovereignty extends to the air space above the historical waters and the seabed and subsoil thereof. This is by no means certain, since the concept of historic waters may well just refer to maritime areas where nationals of coastal States enjoy traditional fishing rights or use to follow certain navigational routes.

"Historic rights" are generally seen as the comprehensive term, covering both historic titles to sovereignty over land and maritime areas and other historic rights not involving full sovereignty. This was understood by the Tribunal. ${ }^{22}$ In the former sense, therefore, "historic rights" and "historic titles" must overlap. Indeed, the two terms are often used interchangeably. The Tribunal correctly observed that "historic rights are, in most instances, exceptional rights. They accord a right that a State would not otherwise hold, were it not for the

16 Sovereignty and Maritime Delimitation in the Red Sea (Eritrea v. Yemen), Case No. 1996-o4, Award of the Tribunal in the Second Stage - Maritime Delimitation 92, at para. 109.

17 Maritime Delimitation and Territorial Questions between Qatar and Bahrain (Qatar v. Bahrain), 2001 I.C.J. Rep. 40 (Mar. 16) (Merits Judgment).

18 Gioia, supra note 14, at para. 19.

19 Case concerning Right of Passage over Indian Territory (Portugal v. India), 196o I.C.J. Rep. 6 (Apr. 12) (Merits Judgment), at para. 39 .

$20 \quad$ Award, supra note 1, at para. 225.

$21 \quad$ Id.

22 Id. 
operation of the historical process giving rise to the right and the acquiescence of other States in the process."23

Notably, the 1957 UN Secretariat study, cited by the Tribunal at para. 220 of the Award, recognised that "historic rights" can be claimed in respect of "the waters of archipelagos and the water area lying between an archipelago and the neighbouring mainland". ${ }^{24}$ China has repeatedly claimed historic rights in respect of the Spratly Islands as a group, as well as their "adjacent waters". 25 The fact that the 1957 study refers also to waters "lying between an archipelago in the neighbouring mainland" demonstrates clearly that such "historic rights" may apply in respect of waters that do not constitute "archipelagic waters" the purposes of Part IV of the Convention.

According to the Tribunal, Article 298(1)(a)(i) refers to "historic [...] titles" and hence relates to claims of sovereignty over maritime areas derived from historical circumstances. ${ }^{26}$ This implies, in the view of the Tribunal, that other historical rights falling short of sovereignty, such as historic rights to the living and non-living resources of the sea, do not fall under the term "historic titles" and hence not under the optional exception clause to jurisdiction as in Article 298(1)(a)(i). ${ }^{27}$ This is not very convincing, in view of the lack of a definition of historical titles in UNCLOS itself and the use of the plural form ("historical titles") in Article 298 as opposed to the use of the singular form in Article 15 on the territorial sea. The latter fact indicates that the phrase historic titles in the context of the jurisdiction exclusion clause of Article 298(1)(a)(i) may have a wider meaning than the one used in Article 15 relating to the delimitation of the territorial sea. As such, the term could easily encompass historic rights beyond those based on full and exclusive sovereignty. It could certainly be the case that China had its "historic rights" firmly in mind when it filed in 2006 its Declaration excluding disputes concerning "historic bays or titles" from the compulsory dispute settlement procedures in UNCLOS. ${ }^{28}$

\footnotetext{
$23 \quad I d$. at para. 268.

24 The Secretariat of the United Nations, supra note 13, at para. 8.

25 See, for example, the statement issued by the Chinese Ministry of Foreign Affairs on 3 o October 2015, cited at para. 187 of the Award.

26 Award, supra note 1, at para. 226.

27 Id.

28 See People's Republic of China, Declaration Under Article 298 (25 August 2006), 2834 UNTS 327. See in Section 2.c.II. the reference to historic rights in Article 14 of the Law on the Exclusive Economic Zone and Continental Shelf of 26 June 1998.
} 
The fact that China has never distinguished between "historic titles" and other historic rights in the context of its claims in the South China Sea is shown by the fact that, as the Tribunal itself observed, China has sometimes described its claims to the maritime areas around and between the Spratly Islands (Nansha Islands) as related to "historic title". ${ }^{29}$

Furthermore, the fact that China has sometimes described its claims in those terms shows that, even if "historic title" does have the narrower legal meaning ascribed by the Tribunal in the Award, China's claims fall within it. Indeed, beyond the singular example cited by the Tribunal in its assessment of China's claims, it is notable that the Tribunal referred elsewhere in the Award to multiple other instances of China having articulated claims to "sovereignty" over waters located within the "nine dash line". ${ }^{30}$ Clearly, some of those assertions of "sovereignty" appear to have related to waters located well beyond $12 \mathrm{~nm}$ of the islands, and thus beyond their territorial seas. Further, although China has not drawn baselines around the Spratly Islands, ${ }^{31}$ we understand that it has raised sovereignty claims over the Spratly Islands and their adjacent waters as a "comprehensive whole" and "since ancient times". ${ }^{32}$

Therefore, the Tribunal had ample evidence before it that China has asserted "sovereignty" claims over the maritime areas of the Spratly Islands, including to waters which are beyond $12 \mathrm{NM}$ of the islands. On the Tribunal's own analysis, such "sovereignty" claims clearly engaged matters of "historic title", linked as they were to historic evidence. And yet, the Tribunal ignored that evidence in concluding that China's claims did not engage questions of "historic title". Again, it is reasonable to assume that China considered that these sovereignty claims with respect to the waters of the South China Sea as falling within in its 2006 Declaration under Article 298. ${ }^{33}$

29 See the Chinese Note Verbale to the Philippines dated 6 July 2011, which the Tribunal concluded was anomalous in the context of other Chinese claims to "historic rights" (Award at paras. 209, 227).

30 See, for example, instances cited by the Tribunal at paras. $654,656,658$ and 659 of the Award, all of which evidence Chinese claims to "sovereignty" over the "waters" of the Nansha islands.

$31 \quad$ Unlike the Philippines, which drew straight baselines enclosing many of the Spratly Island features by way of its Presidential Decree 1596 of 1978.

32 See, for example, statements made by Chinese officials cited at Award, paras. 658-659. Of course, Chinese sovereignty claims to the Spratly Islands and their adjacent waters fell beyond the jurisdiction of the Tribunal.

33 See S. Talmon, The South China Sea Arbitration: Observations on the Award of 12 July 2016, 14 Bonn Research Papers on Public International LaW 1, 10-14 (2018). 
In proceedings concerning territorial disputes submitted to the ICJ, it frequently occurs that a party invokes a historic title or right to the land or maritime territory in question, either in the narrow sense that title emanates from a specific act of discovery and occupation of terra nullius, or in the more general sense of title being based on immemorial possession - that is, possession established for such a long period whose origins cannot be easily determined but are beyond question. ${ }^{34} \mathrm{~A}$ well-known example is the Minquiers and Ecrehos case (UK v. France), ${ }^{35}$ in which France claimed that it possessed an original title to the islets and rocks of the Minquiers and Ecrehos groups. France argued that it always maintained and never lost this title, whereas the UK claimed an ancient title to these territories based upon the conquest of England by the Duke of Normandy in 1066. However, ultimately the Court based its decision on evidence of possession of the disputed islands from more recent times.

Other examples of where international courts and tribunals have addressed claims of historic rights include the following cases:

1) Anglo-Norwegian (U.K. v. Norway) ${ }^{36}$ in which Norway claimed historic title to marine areas beyond the territorial sea;

2) Fisheries Jurisdiction (U.K. v. Iceland) ${ }^{37}$ and Fisheries Jurisdiction (Federal Republic of Germany v. Iceland) ${ }^{38}$ in which the UK and Germany, respectively, claimed historic fishing rights in high seas areas;

3) Continental Shelf (Tunisia/Libya ${ }^{39}$ in which Tunisia claimed a wider belt of territorial sea based upon long-established fishing activities;

4) Land, Island and Maritime Frontier Dispute (El Salvador/Honduras, Nicaragua intervening $)^{40}$ in which the Gulf of Fonseca was claimed as a historical bay by the three coastal States and El Salvador and Honduras asserted their historical titles over some or all of the islands;

5) Sovereignty and Maritime Delimitation in the Red Sea (Eritrea v. Yemen $)^{41}$ in which traditional and artisanal fishing rights of nationals of

See A. Kozłowski, The Legal Construct of Historic Title to Territory in International Law - An Overview, 3 o Polish Yearbook of International Law 61, 63-8o (2010).

35 Minquiers and Ecrehos Case (Fr. v. U.K.), 1953 I.C.J. Rep. 47 (Nov. 17) (Judgement).

36 Anglo-Norwegian Fisheries Case (U.K. v. Nor.), 1951 I.C.J. Rep. 117 (Jan. 18) (Judgement).

37 Fisheries Jurisdiction Case (U.K. v. Ice.), 1974 I.C.J. Rep. 3 (July 25) (Judgement).

38 Fisheries Jurisdiction (F.R.G. v. Ice.), 1974 I.C.J. Rep. 175 (July 25) (Judgement).

39 Continental Shelf, supra note 15.

40 Land, Island and Maritime Frontier Dispute (El Sal. v. Hond.), 199o I.C.J. Rep. 92 (Sept. 13) (Judgement) at 351 .

41 Sovereignty and Maritime Delimitation in the Red Sea, supra note 16. 
both Eritrea and Yemen were at stake within areas delimited as forming the other State's EEZ;

6) Case concerning Maritime Delimitation and Territorial Questions (Qatar v. Bahrain $)^{42}$ relating to Bahrain's claim to exclusive rights over the exploitation of the pearling banks;

7) Case concerning the sovereignty over Pulau Ligitan and Pulau Sipadan (Indonesia v. Malaysia), in which the Court's finding on the long usage of turtle egg collection on Sipadan played a determining role in confirming Malaysia's sovereignty; ${ }^{43}$ and

8) Case concerning sovereignty over Pedra Branca/Pulau Batu Puteh, Middle Rocks and South Ledge (Malaysia v. Singapore), in which the Court acknowledged the centuries-old rule of the Sultanate of Johor over its maritime domains, including the Straits of Singapore. ${ }^{44}$

It is notable that several of these cases post-date the conclusion of UNCLOS. In fact, in Tunisia/Libya, in which the ICJ was authorised by the Parties' Special Agreement to consider "new accepted trends", 45 the ICJ ruled that the emergent trends in the new law of the sea are to be found in UNCLOS.

The Court held that:

... the Court would have had proprio motu to take account of the progress made by the Conference even if the Parties had not alluded to it in their Special Agreement; for it could not ignore any provision of the draft convention if it came to the conclusion that the content of such provision is binding upon all of the international community because it embodies or crystallizes a pre-existing or emergent rule of customary law. ${ }^{46}$

However, this did not preclude the Court in this and subsequent cases from recognising the potential for the continued existence of historic rights, in parallel with maritime entitlements enshrined in the Convention. As the Court observed, " $[\mathrm{i}] \mathrm{t}$ is clearly the case that, basically, the notion of historic rights or waters and that of the continental shelf are governed by distinct legal régimes in customary international law."47

\footnotetext{
$42 \quad$ Maritime Delimitation and Territorial Questions, supra note 17, at 40.

43 Sovereignty over Pulau Ligitan and Pulau Sapadan (Indon. v. Malay.), 2001 I.C.J. Rep. 575 (Oct. 23) (Judgement), at 625 .

44 Sovereignty over Pedira Branca/Pulau Batu Puteh, Middle Rocks and South Ledge (Malay.v. Sing.), 2008 I.C.J. Rep. (May 23) (Judgement), at 12.

45 Continental Shelf, supra note 15 , at para. 4.

$46 \quad$ Id. at para. 24.

47 Id. at para. 100.
} 
2.2.3 The Alleged "Exclusive" Nature of UnCLOS and the Tribunal's Finding that It "Supersedes" Historic Rights beyond Territorial Sea

In the Award, the Tribunal asserts that UNCLOS is nowadays the sole source for the establishment of sovereign maritime rights and that, to the extent that rights are claimed beyond the limits imposed by UNCLOS, these are simply invalid and nullified. This is based upon the presumption by the Tribunal that the Convention supersedes any previously existing historic rights in general international law. This implies that the regimes established by UNCLOS for the EEZ (Part v) and continental shelf (Part VI) have replaced any prior Chinese historical rights over the living and non-living natural resources in the South China Sea. As the Tribunal holds:

... the system of maritime zones created by the Convention was intended to be comprehensive and to cover any area of the sea and the seabed. The same intention for the Convention to provide a complete basis for the rights and duties of the States Parties is apparent in the Preamble, which notes the intention to settle all issues relating to the law of the sea' and emphasises the desirability of establishing 'a legal order for the seas. ${ }^{48}$

Consequently, in the view of the Tribunal, "the Convention supersedes earlier rights and agreements to the extent of any incompatibility", and "the text and context of the Convention [... are] clear in superseding any historic rights that a State may once have had in the areas that now form part of the exclusive economic zone and continental shelf of another State". ${ }^{49}$ In short, the Tribunal concluded that "the Convention [...] leaves no space for an assertion of historic rights." 50

This conclusion was critical to the Tribunal's substantive conclusions with respect to Submission nos. 1 and 2. However, it is subject to doubt on multiple fronts.

Three preliminary points can be made. First, an essential premise of the Tribunal's conclusion that the Convention "leaves no space" for China's "historic rights" claims in the maritime areas of the South China Sea was that those claims are limited to living and non-living natural resources. It is striking that the Tribunal's substantive analysis of China's "historic rights" for the purposes of Submission nos. 1 and 2 focused exclusively on "rights and jurisdiction over

48 Award, supra note 1, at para. 245.

49 Id. at paras. 246-247.

$5^{\circ} \quad I d$. at para. 261. 
living and non-living resources".51 The Tribunal did not address substantial attention to the possibility that China's claims may extend beyond natural resources. ${ }^{52}$ To the extent that China's claims to "historic rights" extend beyond natural resources, even the Tribunal confirmed that they may not contradict UNCLOS and thus be more readily preserved. ${ }^{53}$

A second premise to the Tribunal conclusion appears to have been that China claims "exclusive" rights within the "nine dash line". ${ }^{44}$ This ignores indications to the effect that China's claims may not be "exclusive" in nature. ${ }^{55}$ Even if the Tribunal was correct to conclude that there was no evidence of China having any historic right to the exclusive use of the resources of the South China Sea prior to UNCLOS, ${ }^{56}$ this should not preclude China from claiming non-exclusive historic rights within the "nine dash line" (for example, of the kind enjoyed by fisherfolk of both States in the Eritrea/Yemen case).

Third, it is striking that the Tribunal did not consider the possibility that China's claims to "historic rights" arise in the connection with the waters of the Spratly Islands as a whole, whether as an offshore archipelago or otherwise. This was despite the fact that the 1957 UN Secretariat study on "historic bays", cited by the Tribunal in the Award, explicitly recognised that "historic rights" can be claimed in respect of "the waters of archipelagos and the water area lying between an archipelago and the neighbouring mainland". ${ }^{57}$ This is particularly surprising given the Tribunal's acknowledgement later in the Award, in Chapter VI, of the historic presence of Chinese fishermen throughout the Spratly Islands as a whole. ${ }^{58}$ As explained in the critique of Chapter vi below, the Tribunal limited its analysis of the potential for claims based upon the Spratly Islands collectively to findings that the features cannot be enclosed within a system of archipelagic or straight baselines under the Convention.

$51 \quad I d$. at paras. $234-35,239,246,262$.

52 See, e.g., S. Wu \& K. Zou, Arbitration Concerning the South China Sea 132, 140 (2016). For instance, according to Dr. Wu and Dr. Zou, China's claims of historic rights beyond natural resources include fishing rights, navigation rights, maritime law enforcement and marine scientific research rights.

53 Award, supra note 1, at para. 238(b).

54 Id. at paras. 243, 258, 270.

55 Wu \& Zou, supra note 52 , at 140.

56 Award, supra note 1, at para. 261.

57 The Secretariat of the United Nations, supra note 13, at para. 8.

58 For example, the Tribunal referred in Chapter VI of the Award to evidence showing that Chinese fishing communities were present in the Spratlys "for comparatively long periods of time, with an established network of trade and intermittent supply". Award, supra note 1 , at paras. $597-601$. 
This is irrelevant to the entirely separate question of whether China may have enjoyed "historic rights" within the waters of the archipelago.

In any event, and more importantly, for at least eight reasons the Tribunal's claim of exclusiveness and exhaustiveness of the Convention, such that it "supersedes" any pre-existing historic rights in areas that became EEZ or continental shelf, is untenable under international law.

First, as opposed to a constitution or a formulation of general norms from which no derogation is permitted (jus cogens), the Convention is an ordinary multilateral treaty, however comprehensive and significant its provisions may be. ${ }^{59}$ It does not contain an Article 103 UN Charter-type of provision according the obligations under this treaty in matters not regulated by it a superior status above other obligations of international law, and placing the treaty in a hierarchically higher position than other treaties and other sources of international law. ${ }^{60}$

Second, UNCLOS itself recognizes the continued validity of general international law alongside the Convention. Thus, in paragraph 8 of its Preamble the Convention states that "matters not regulated by this Convention continue to be governed by the rules and principles of general international law". Obviously, general international law includes customary international law which, in turn, includes historic rights. Moreover, general international law is also referred to in a considerable number of other provisions of UNCLOS. ${ }^{61}$

Third, the ongoing relevance of customary international law alongside the Convention is confirmed in the practice of tribunals established under the compulsory procedures of the Convention entailing binding decisions. Relevant international jurisprudence demonstrates amply that the applicable law of UNCLOS tribunals is not limited to UNCLOS only but also includes, as per Article 293, other rules of international law not incompatible with UNCLOs. For example, in The Arctic Sunrise Arbitration (Netherlands v. Russia), the Tribunal stated:

59 The Convention regulates the main uses (albeit not all) of the seas and the oceans and establishes the principal maritime zones (i.e., territorial sea, contiguous zone, EEZ, continental shelf, high seas and deep seabed). Currently, UnCLOS has 167 State parties and the EU is also a party.

6o Article 103 of the UN Charter provides: "In the event of a conflict between the obligations of the Members of the United Nations under the present Charter and their obligations under any other international agreement, their obligations under the present Charter shall prevail".

61 These include Arts. 2(3), 19, 22, 74, 83, 87(1), 293 \& 295. Wood spotted some 40 provisions with express references to general international law in UnCLos. See M. Wood, The International Tribunal for the Law of the Sea and General International Law, 22 International Journal of MARitime AND COASTAL LAW 351, 359 (2007). 
Both arbitral tribunals and ITLOS have interpreted the Convention [UNCLOS] as allowing for the application of relevant rules of international law. Article 293 of the Convention makes this possible. For instance, in M/V "SAIGA" No. 2, ITLOS took account of general international law rules on the use of force in considering the use of force for the arrest of a vessel. ${ }^{62}$

The Tribunal continued in the same award:

In determining the claims by the Netherlands in relation to the interpretation and application of the Convention, the Tribunal may, therefore, pursuant to Article 293, have regard to the extent necessary to rules of customary international law, including international human rights standards, not incompatible with the Convention, in order to assist in the interpretation and application of the Convention's provisions that authorise the arrest or detention of a vessel and persons. ${ }^{63}$

Fourth, international jurisprudence confirms specifically that customary regimes of historic rights continue to exist in parallel with separate regimes covering maritime entitlements under international law. Thus, in Continental Shelf (Tunisia/Libya), the ICJ observed in relation to the continental shelf (now governed by Part VI of UNCLOS) that: "It is clearly the case that, basically, the notion of historic rights or waters and that of the continental shelf are governed by distinct legal régimes in customary international law."64 Judge Oda elaborated on this in his Dissenting Opinion in that case, referring to "the principle that any historic fishing right based on longstanding practice should be respected whatever the status of the submerged areas under the new régime. $[\ldots][\mathrm{T}]$ he concept of the exclusive economic zone $[. .$.$] has nothing to$ do with historic titles". 65

Fifth, international jurisprudence since UNCLOs further confirms that historic fishing rights of one State (or its nationals) can continue to exist as a

62 The Arctic Sunrise Arbitration (Netherlands v. Russia) Case No. 2014-02 (14 August 2015), Award on the Merits, para. 191.

63 Id. para. 198. Other relevant cases endorsing this position: The M/V Saiga (No. 2) Case (Saint Vincent v. Guinea), 1999 I.T.L.O.S. No. 2 (Judgment of July 1) at para. 155; Barbados v. Trinidad \& Tobago, Case No. 2004-02 (11 Apr. 2006), Award, para. 222.

64 Continental Shelf, supra note 15 , at para. 100.

65 Case concerning the Continental Shelf (Tunisia v. Libya), 1982 I.C.J. Rep. 18 (Dissenting Opinion of Judge Oda), at para. 88. Here, Judge Oda did not depart from the majority judgment of the Court. 
matter of general international law even within the exclusive economic zone of another State. In Eritrea/Yemen, the Tribunal acknowledged the existence and continuation of pre-UNCLOS historic rights within the territorial seas and EEzs of each of the Parties, in the form of a traditional fishing regime. The Tribunal's attempts in the Award to distinguish that case on the basis of the broader "applicable law" in Eritrea/Yemen, and with reference to the fact that Eritrea/Yemen "was not an arbitration under Annex viI to the Convention", are unconvincing. ${ }^{66}$ Certainly, they do not explain the Tribunal's conclusion, despite its narrower "applicable law", that China's claims to historic rights, or other sovereign rights or jurisdiction existing outside of UNCLOS, are "without lawful effect to the extent that they exceed the geographic and substantive limits of China's maritime entitlements under the Convention".67 On the contrary, the Eritrea/Yemen Award explicitly recognises the ongoing legal validity at general international law of historic rights within EEZ areas, despite the fact that such rights (as in that case) can exceed the geographic and substantive limits of maritime entitlements under the Convention. It also disproves the Tribunal's separate finding that "historical navigation and fishing, beyond the territorial sea, cannot [...] form the basis for the emergence a historic right". 68

Sixth, Article 311 of UNCLOS deals explicitly with how the Convention relates to other conventions and international agreements. This Article only stipulates prevalence of UNCLOS over the four 1958 Conventions on the Law of the Sea, and prevalence of Article 136 (relating to the common heritage of mankind) with respect to which no amendments to the basic principles are allowed.

Seventh, the Tribunal provides no legal rationale or justification for its conclusion that "[Article 311] applies equally to the interaction of the Convention with other norms of international law, such as historic rights, that do not take the form of an agreement". ${ }^{69}$ There is nothing in the text of Article 311 that provides for this. ${ }^{70}$ Its scope extends only to the relation of the Convention to other conventions and international agreements, not to general international

\footnotetext{
66 Award, supra note 1, at para. 259.

67 See id. at para. 278 and merits dispositif no. 2.

68 Id. at para. 270.

69 Id. at para. 235 .

70 See also P.S. Rao, The South China Sea Arbitration(The Philippines v. China): Assessment of the Award on Jurisdiction and Admissibility, ${ }_{15}$ Chinese Journal of International LAW 265, 293 (2016).
} 
law and customary international law. Since the Nicaragua judgment, and as confirmed by Judge Oda in Continental Shelf (Tunisia/Libya), it is widely acknowledged that "customary international law continues to exist and to apply, separately from international treaty law, even where the two categories of law have an identical content".71

Eighth and lastly, the Convention itself provides for a number of limitations and exceptions in Articles 297 and 298 to the compulsory dispute settlement procedures entailing binding decisions (provided for in Part XV, Section 2 of the Convention)..$^{72}$ This is another indication of the not entirely exclusive nature of UNCLOS, and the fact that a broad range of law of the sea disputes (including those related to historic title claims) can only be resolved outside the Convention.

\subsubsection{Interim Conclusion with Respect to Submission No. 1}

The finding of the Tribunal that UNCLOs "leaves no space for an assertion of historic rights" is highly questionable. The concepts of "historic titles" and "historic rights" are not as clearly and consistently distinguished as the Tribunal asserts in its Award. Rather, the two terms are often used interchangeably. Historic rights can and do continue to exist next to and independent from UNCLOS, as confirmed by the award in the Eritrea/Yemen case.

In effect, the Tribunal concludes that there no longer exists a body of general international law rules in parallel with the Convention. This is incorrect. Therefore, the conclusion of the Tribunal in paragraph 278 of the Award that "the Convention superseded any historic rights or other sovereign rights or jurisdiction in excess of the limits imposed therein" is probably wrong. This provides a serious basis to challenge the Tribunal's substantive findings with respect to Submission no. 1 (and thus merits dispositif no. 1). As elaborated in the following Section, it also provides a serious basis to challenge the Tribunal's substantive findings with respect to Submission no. 2 (and thus merits dispositif no. 2).

71 Military and Paramilitary Activities in and Against Nicaragua (Nicar. v. U.S.), 1986 I.C.J. Rep. 14 (June 27) (Judgment), at para. 179.

72 Disputes excluded by Art. 297 or exempted by Art. 298 of the Convention from application of the compulsory dispute settlement procedures may be submitted to such procedures only by agreement of the parties to the dispute. 
2.3 The Tribunal's Conclusions: that China's Claims to Historic Rights, or Other Sovereign Rights or Jurisdiction, with Respect to the Maritime Areas of the South China Sea Encompassed by the "Nine Dash Line" are Contrary to the Convention and Without Lawful Effect to the Extent that They Exceed the Geographic and Substantive Limits of China's Maritime Entitlements under the Convention: and that the Convention "Superseded" Any Historic Rights, or Other Sovereign Rights or Jurisdiction, in Excess of the Limits Imposed Therein (Philippines Submission No. 2; Tribunal Merits Dispositif No. 2) The Philippines' Submission no. 2 reads: ${ }^{73}$

China's claims to sovereign rights jurisdiction, and to "historic rights" with respect to the maritime areas of the South China Sea encompassed by the so-called "nine dash line" are contrary to the Convention and without lawful effect to the extent that they exceed the geographic and substantive limits of China's maritime entitlements expressly permitted by UNCLOS.

The so-called "nine dash line" plays a central role in the discussion on the extent of China's historic rights in the South China Sea. The background, meaning and implications of this line are discussed subsection (1). Subsection (2) surveys some of China's relevant post-war declarations and legislation on the law of the sea, followed by interim conclusions in subsection (3).

2.3.1 The "Nine Dash Line": Background, Meaning and Implications The "nine dash line", originally an eleven-dash line and also called the U-shaped line or dotted line, first appeared in some Chinese atlases following the end of WwII and the end of Japan's occupation of the Xisha and Nansha Islands. In 1947, the Chinese Ministry of the Interior published a list of 172 geographical names, in both Chinese and English, for the islands in the South China Sea. Subsequently, in February 1948 the Chinese government released through the Commerce Press in Beijing an official atlas of all national administrative districts, which also depicted the eleven-dash line. In 1949, the four island groups in the South China Sea (Xisha or Paracel Islands, Dongsha or Patras Islands, Zhongsha Islands, and Nansha or Spratly Islands) and other attached 
islands were placed under the authority of the Hainan District of Guan Dong Province. ${ }^{74}$

In 1953, two of the eleven dashes were removed following an understanding between China and Viet Nam on their maritime borders in the Gulf of Tonkin. Ever since, the "nine dash line" remained in this form on Chinese maps and in its atlases. It was this map showing the "nine dash line" which, on 7 May 2009, was appended to two Notes Verbales to the UN Secretary-General, through which China responded to the joint submission of Malaysia and Viet Nam on 6 May 2009 to the UN Commission on the Limits of the Continental Shelf. ${ }^{75}$ This prompted a series of exchanges of diplomatic notes with Viet Nam, Malaysia, the Philippines and Indonesia. In such exchanges the "nine dash line" consistently features as a point of reference for China's claim to rights "formed throughout the long course of history and [...] maintained by the Chinese government consistently", ${ }^{76}$ and "supported by abundant historical and legal evidence".77

There is considerable logic to the observation by Ghao and Bing Bing that around 1947: "The underlying reason for the eleven-dash line was presumably to reaffirm and reiterate China's sovereignty over the islands group in the South China Sea at the beginning of a new, postwar era." ${ }^{78}$ It appears that the dotted line signifies the general geographical scope of China's authority (imperium or domaine réservé) over the South China Sea rather than a specific boundary, demarcating precisely its territory, internal waters and territorial seas in the South China Sea.

There has also been speculation that the dashed line roughly follows the 2oo-meter isobath, in the context of the emergence of international discussions on rights to the continental shelf following the 1945 Truman Proclamation on this, or served a potential delimitation purpose by drawing more or less

74 See for a summary of the historic evolution of the nine-dash line, Z. Ghao \& B.B. Jia, The Nine Dash Line in the South China Sea: History, Status, and Implications, 107 AMERICAN Journal of International LAW 98, 100-o8 (2013).

75 Note Verbale from the Permanent Mission of the People's Republic of China to the United Nations to the Secretary-General of the United Nations, No. CML/17/2009 (7 May 2009); Note Verbale from the Permanent Mission of the People's Republic of China to the United Nations to the Secretary-General of the United Nations, No. CML/18/2009 (7 May 2009).

76 Ministry of Foreign Affairs, People's Republic of China, Briefing by Xu Hong, DirectorGeneral of the Department of Treaty and Law on the South China Sea Arbitration Initiated by the Philippines (12 May 2016), on the Ministry of Foreign Affairs of China website at www.fmprc.gov.cn/mfa_eng/wjdt_665385/zyjh_665391/t1364804.shtml.

$77 \quad$ Note Verbale from the Permanent Mission of the People's Republic of China to the United Nations to the Secretary-General of the United Nations, No. CML/8/2011 (14 April 2011).

78 Ghao \& Jia, supra note 74 , at 103. 
the median lines between the Chinese islands in the South China Sea and the opposite coasts of the neighbouring States. ${ }^{79}$ In either of these scenarios, of course, the "nine dash line" would constitute a claim to "historic titles", even within the meaning ascribed to that term by the Tribunal in the Award, and would thus fall outside the Tribunal's jurisdiction by virtue of China's Article 298 Declaration.

\subsubsection{Declarations and Legislation of China in the Field of the Law of the Sea}

As regards legislative and declaratory acts in the post-war period, China issued its Declaration on the Territorial Sea on 4 September 1958, promulgating a $12 \mathrm{NM}$ territorial sea for both its mainland and its coastal and off-lying islands. ${ }^{80}$ On 25 February 1992, in the context of the forthcoming ratification of the 1982 Convention on the Law of the Sea, China enacted a new Law on the Territorial Sea and the Contiguous Zone ("1992 Law"), including for the four island groups of the South China Sea as well as for all other islands belonging to China in its Article $2 .{ }^{81}$

China ratified UNCLOS on 7 June 1996. On the occasion of depositing its instrument of ratification with the UN Secretary-General, China expressly reaffirmed "its sovereignty over all its archipelagos and islands as listed in article 2 of the [1992 Law]". In accordance with the Convention, China proclaimed its EEZ in an official declaration on 7 June 1996. Thereupon, it promulgated the Law on the Exclusive Economic Zone and the Continental Shelf on 26 June 1998 ("1998 Law"). ${ }^{82}$ Article 14 of the 1998 Law provides that: "No provisions of this Law can prejudice historic rights of the People's Republic of China". Notably, China uses the general concept of "historic rights" which, as discussed in Section II.B above and acknowledged in the Award, is broadly considered as including the concept of "historic titles".

Several other declarations are of relevance. As discussed above, China made on 25 August 2006 a Declaration under Article 298(1)(a)(i), excluding various categories of disputes, including those concerning maritime boundary delimitations or those involving "historic bays and titles", from the compulsory

\footnotetext{
$79 \quad$ Id. at 109.

80 These and other legal documents referred to in this paragraph can be found in Collection of the Sea laws and Regulations of the People's Republic of China (3rd ed. 2001).

81 See Art. 2 of the 1992 Law on the Territorial Sea and Contiguous Zone.

82 Adopted at the 3 rd Meeting of the Standing Committee of the Ninth National People's Congress on June 26, 1998 and promulgated by Order No. 6 of the President of the People's Republic of China on June 26, 1998.
} 
dispute settlement procedures entailing binding decisions as contained in Part XV of UNCLOS. ${ }^{83}$

Notwithstanding its policy of non-appearance and non-participation in the arbitration proceedings initiated by the Philippines, China issued on several occasions public statements or position papers on the South China Sea Arbitration. On 7 December 2014 it deposited a Note Verbale with the PCA, attaching an extensive Position Paper in which it reiterated its historic rights in the South China Sea and explained why in its view the Tribunal lacked jurisdiction in the case. ${ }^{84}$ Similarly, the Ministry of Foreign Affairs of the People's Republic of China issued a statement on 30 October 2015 in response to the Tribunal's Award on Jurisdiction and Admissibility of the day before, in which the Ministry declared that Award to be "null and void" and to have "no binding effect on China". ${ }^{55}$

In the Award, the Tribunal found that China's claim to historic rights, or other sovereign rights or jurisdiction, with respect to the maritime areas of the South China Sea encompassed by the "nine dash line" were contrary to the Convention and without lawful effect to the extent that they exceed the geographic and substantive limits of China's maritime entitlements under the Convention. Therefore, the Tribunal concluded with respect to Submission no. 2 that the Convention leaves no space for an assertion of historic rights based upon the "nine dash line" beyond the rights emanating from the maritime zones included in the Convention, most notably the territorial sea, the EEZ and the continental shelf. ${ }^{86}$

For the reasons set out at subsection 2.2.2 above, this conclusion, which formed the heart of the Tribunal's dispositif no.2, is subject to substantial doubt as a matter of law (even if the Tribunal had jurisdiction over this question, which it likely did not for the reason set out at subsection $\mathrm{A}$ (ii) above).

83 See People's Republic of China, Declaration under Article 298 (25 August 2006), 2834 UNTS 327. The relevant part reads: "The Government of the People's Republic of China does not accept any of the procedures provided for in Section 2 of Part XV of the Convention with respect to all the categories of disputes referred to it in paragraph $1(a)$ (b) and (c) of Article 298 of the Convention".

84 See the English text of the Position Paper of the Government of China dated 7 December 2014, also published in Chinese Society of International Law, The South China Sea Arbitration Awards: A Critical Study, 17(2) CHINESE JouRnAL OF INTERNATIONAL LAW 207 at 655 (2018) (hereinafter Critical Study), on the Ministry of Foreign Affairs of China website at www.fmprc.gov.cn/nanhai/eng/snhwtlcwj_1/tı368895.htm.

85 Id. at 679 .

86 Award, supra note 1, at paras. 261-62, 278. 


\subsubsection{Interim Conclusion with Respect to Submission No. 2}

The "nine dash line" has for more than half a century been a consistent point of reference for China and for a long period prompted no coherent responses by neighbouring coastal States until 2009. Its particular background is the re-assertion of control over the island groups of the South China Sea in the immediate post-war period and the pre-empting of potential interference by third States. It is too simplistic for the Tribunal to completely discard the line, and the rights to which it refers, on the basis that the Convention "supersedes" all historic rights which do not exactly accord with the provisions of UNCLOS. Rather, as explained above and as international jurisprudence confirms, historic rights regimes in maritime areas, including the EEZ, are capable of being preserved in international law notwithstanding UNCLOS.

\subsection{Assessment and Conclusions on the Findings of the Tribunal on Submissions Nos. 1 and 2 \\ 2.4.1 Jurisdiction}

There are strong arguments indicating that the Tribunal incorrectly found jurisdiction in the Award over Submission nos. 1 and 2. First, in order properly to decide on the maritime rights and entitlements of China in the South China Sea, the Tribunal had to assess the underlying issue of the territorial title of China to sovereignty over the islands and maritime areas of the South China Sea. However, these issues are explicitly excluded from the compulsory dispute settlement procedures under Part XV of UNCLOS and as per the Declaration made by China under Article 298(1)(a)(i). Second, the Tribunal's conclusion that China's claims within the "nine dash line" involve issues of "historic rights" but not "historic title" (for the purpose of China's Article 298 Declaration) is legally unsound. Third, evidence before the Tribunal confirmed that, in any event, China claims elements of "sovereignty" (and thus "historic title") within the "nine dash line" (thus satisfying the Tribunal's legal test for the purpose of China's Article 298 Declaration). Fourth, the Tribunal did not have jurisdiction to declare that China's "nine dash line" and related "historic rights", as well as being "contrary to the Convention", were "without lawful effect". Indeed, to the extent that it had such jurisdiction, it should (like the Eritrea/Yemen tribunal) have declared that such "historic rights" can persist alongside the Convention.

2.4.2 Continued Relevance of Historic Maritime Rights: UNCLOS Does Not Mark the End of History

A central issue in the South China Sea Arbitration is the continued validity and the legality of historic maritime rights after the conclusion and entry into force of UNCLOS. Should these rights be judged only in the context of UNCLOS 
or also from a general international law perspective? This is the principal question raised in the context of Philippines' Submission no. 1, but is also of critical relevance in connection with its Submission no. 2. The Tribunal reduced this key question to the status of historic rights in the context of UNCLOS only. This is a classic case of "tunnel vision". The Tribunal concluded that UNCLOS "superseded" and thus wiped out, all historic rights within maritime areas that would otherwise constitute EEZ and continental shelf under UNCLOS. ${ }^{87}$ This is a radical proposition from a legal perspective and has far-reaching consequences, nullifying in principle (beyond the South China Sea context) all historic rights that coastal States may have to maritime areas beyond their territorial seas. Moreover, the proposition lacks legal foundation as it is contradicted by the text of UNCLOS and by international jurisprudence, both of which provide for the ongoing co-existence of historic rights in maritime space. In addition, the Tribunal did not consider in any detail the possibility that China's claims to "historic rights" within the "nine dash line" might extend beyond rights with respect to natural resources, or might not be exclusive in nature, or might be centred around the Spratly Islands collectively, as a group or offshore archipelago.

However comprehensive a treaty UNCLOS may be, and however significant its status, it cannot and does not extinguish or supersede all historical maritime rights existing under general international law. The alfa et omega of the international law of the sea comprises more than UNCLOS. Rather, the concept of "historic rights" is one which is long supported by state practice and international jurisprudence, both before and since UNCLOS. As such, historic rights to and within maritime areas continue to be part and parcel of general international law. Contrary to what the Tribunal appears to suggest, UNCLOS does not mark the end of history or extinguish historic rights that may exist in a variety of guises around the world.

On the contrary, UNCLOS itself provides ample room for the continued validity and applicability of general international law, including customary international law, which can obviously serve as the source of historic rights. These can relate to both territorial claims to certain land and maritime areas around or between it and to certain sovereign rights to the living (in the sense of 'habitual fishing by nationals' ex Article 62(3) of UNCLOS) and non-living resources in a certain area.

$87 \quad I d$. at paras. $246,247,262,278$. 


\subsubsection{The "Nine Dash Line" is Not "Without Lawful Effect"}

Submission no. 2 focuses on the continued validity and legality of the "nine dash line" and related claims to "historic rights". Also, here the Tribunal takes a radical position: it concludes that the line and related claims to sovereignty and historic rights are contrary to UNCLOS and therefore without legal effect to the extent that China's maritime claims exceed the geographic and substantive limits of its entitlements under the Convention. China has never claimed all maritime waters encompassed by the "nine dash line" as internal waters, territorial sea or even EEz. Nor is it clear that China ever claimed exclusive sovereignty over the natural resources of the South China Sea. Rather, it has stated that it respects freedom of navigation in and overflight over the waters in (at least part of) the maritime areas encompassed by the "nine dash line". The "nine dash line" has been, for 50 years, a consistent point of reference for China. But there is no particular international obligation incumbent upon China to specify what exactly is meant by this historic line and its related historic rights. A comprehensive exposition could most likely only be expected in proceedings concerning territorial sovereignty over land and maritime areas of the South China Sea, or in the context of specific maritime boundary delimitation with neighbouring coastal States. However, these issues are explicitly excluded from the scope of the international dispute settlement procedures under Part XV of UNCLOS and are matters for negotiation or other agreed means of international dispute settlement voluntarily chosen by the parties concerned.

The Tribunal's Findings on the Status of Features in the South China Sea (Philippines Submission Nos. 3 to 7 ; Award Chapter VI) under Article 13 of UNCLOS (Philippines Submission Nos. 4 and 6; Tribunal Merits Dispositif Nos. 4 and 5)

Article 13 of UNCLOS provides as follows:

Article 13 Low-tide elevations

1. A low-tide elevation is a naturally formed area of land which is surrounded by and above water at low tide but submerged at high tide. Where a low-tide elevation is situated wholly or partly at a distance not exceeding the breadth of the territorial sea from the mainland or an island, the low-water line on that elevation may be used as the baseline for measuring the breadth of the territorial sea. 
2. Where a low-tide elevation is wholly situated at a distance exceeding the breadth of the territorial sea from the mainland or an island, it has no territorial sea of its own.

The Tribunal made several observations in its interpretation of Article 13 and legal approach to the classification of low-tide elevations, with which we broadly agree. The Tribunal noted that the inclusion of the term "naturally formed" in the definition of both a low-tide elevation and an island "indicates that the status of the feature is to be evaluated on the basis of its natural condition".88 The significance of the Tribunal's observation, that "human modification cannot change [...] a low-tide elevation into an island", is uncontroversial. ${ }^{89}$ The Tribunal further observed that many of the South China Sea features in question had been "subjected to substantial human modification" 90 and that UNCLOS required that "the status of the feature be ascertained on the basis of its earlier, natural condition, prior to the onset of significant human modification." ${ }^{91}$

The Tribunal then noted, also un-controversially, that because Article 13(2) states that a low-tide elevation does not generate a territorial sea of its own (except when it falls within the breadth of a territorial sea generated from a high-tide feature or mainland), it is not entitled to an EEZ or continental shelf. ${ }^{92}$ With respect to the status of low-tide elevations, the Tribunal observed correctly that low-tide elevations do not form part of the land territory of a State in a legal sense, and that they "cannot be appropriated". Rather, they coastal State only has sovereignty over low-tide elevations to the extent that they are situated within its territorial sea, since the State has sovereignty over the territorial sea itself. ${ }^{93}$

The Tribunal noted that both Articles 13 and 121 of UNCLOS use the term "high tide" and observed that "high tide" was "not a technical term" that could be interpreted in different ways. ${ }^{94}$ Consequently , the Tribunal considered that "States are free under the Convention to claim a high-tide feature or an island on the basis of any high-water datum that reasonably corresponds to the ordinary meaning of the term "high tide" in Articles 13 and 121." ${ }^{\text {95 }}$

$\begin{array}{ll}88 & I d . \text { at para. } 305 . \\ 89 & I d . \\ 90 & I d . \text { at para. } 306 . \\ 91 & I d . \\ 92 & I d . \text { at para. } 308 . \\ 93 & I d . \text { at para. } 309 . \\ 94 & I d . \text { at para. } 311 . \\ 95 & I d .\end{array}$


When it came to the evidence, the Tribunal noted that the most accurate determination of whether a feature was above or below water at high tide would be based on a "combination of methods", including "direct, in-person observation". ${ }^{96}$ However, the Tribunal observed that such direct observation was "impossible where human modifications have obscured the original status of a feature or where political considerations restrict in-person observation". ${ }^{97}$ The Tribunal thus acknowledged the "absence of full information" in reaching its findings as regards the status of the features.

The Tribunal considered that, "given the impossibility of direct, contemporary observation, ${ }^{\prime \prime 8}$ the most relevant evidence relating to the status of features in the South China Sea was to be found in nautical charts, records of surveys and sailing directions. ${ }^{99}$ All of this evidence was necessarily historic in nature, much of it deriving from British and Japanese surveys conducted during the 19th and early 2oth centuries and nautical charts at a scale of no better than 1: $150,000.100$

The Tribunal's approach goes against international jurisprudence and leading commentary, which clearly favours contemporaneous evidence, where available, over historical charts or surveys, unless these form an integral part of a particular treaty. ${ }^{101}$ In Nicaragua v. Colombia, the ICJ questioned the probative value of historical surveys and preferred contemporary (including photographic) evidence presented by Colombia for the purposes of determining the status of Quitasueño and other disputed features under the Convention. ${ }^{102}$

The Tribunal's findings were therefore, even on its own view, based upon imperfect evidence. Had the Tribunal had access to evidence based upon contemporary, direct observation of features such as Mischief Reef and Second Thomas Shoal in their natural form, its conclusions that those features are

\footnotetext{
$96 \quad$ Id. at para. 321.

$97 \quad$ Id.

$98 \quad I d$. at para. 327.

99 Id.

100 Id. at paras. $327-32$.

101 See, in particular, Frontier Dispute (Burkina Faso v. Republic of Mali), 1986 I.C.J. Rep. 583 (Judgment), at para. 56, "Since relatively distant times, judicial decisions have treated maps with a considerable degree of caution [...] maps can still have no greater legal value than that of corroborative evidence endorsing a conclusion at which a court has arrived by other means unconnected with the maps. In consequence, except when the maps are in the category of a physical expression of the will of the State, they cannot in themselves alone be treated as evidence of a frontier, since in that event they would form an irrebuttable presumption, tantamount in fact to legal title".

102 Territorial and Maritime Dispute (Nicar. v. Colom.), 2012 I.C.J. Rep. (Nov. 19) (Judgment), at paras. $35^{-3} 8$.
} 
low-tide elevations may have been very different. Therefore, to the extent that such contemporary (including photographic and survey) evidence is available, it would likely be of more legal weight than the historic evidence relied upon by the Tribunal in its Award. Of course, such evidence will only be available to the extent that human modifications have not concealed the natural status of the feature. ${ }^{103}$

The Tribunal's Conclusion that Mischief Reef and Second Thomas Shoal are Low-Tide Elevations and Thus Not Capable of Appropriation (Philippines Submission No. 4; Tribunal Jurisdiction Dispositif No. 2(B) and Merits Dispositif Nos. 3 and 4) The Tribunal concluded that Mischief Reef and Second Thomas Shoal are below water at high tide and therefore constitute low-tide elevations for the purposes of Article 13 of UNCLOS. ${ }^{104}$ As such, the Tribunal found that they are incapable of appropriation as a matter of international law. ${ }^{105}$

The Tribunal's finding that Mischief Reef and Second Thomas Shoal were low-tide elevations was a pre-requisite for the Tribunal's acceptance of jurisdiction in respect of Philippines Submission nos. 5, 8, 9, 12, and for a number of its substantive findings on the merits (particularly dispositif nos. 7, 10, 14 and $16(\mathrm{a})$ and $(\mathrm{d}))$. In addition, one commentator has observed:

by not finding any feature to be an island, the result was that two of the most contested features - Mischief Reef and Second Thomas Shoal (which the Tribunal had found to be low-tide elevations) - are thus located with the established exclusive economic zone of the Philippines, and as it is not within 200 nautical miles of any feature to which China could possibly claim sovereignty, these key features remain part of the maritime entitlement of the Philippines. It is worthwhile pausing here to reflect what the Tribunal has done. It has not ruled on sovereignty but, in effect, it has. By finding that something is a low-tide elevation (the firstorder question), incapable of being possessed by means of territoriality, the Tribunal has in essence ruled out the question of sovereignty [over Mischief Reef and Second Thomas Shoal] (a second-order question). ${ }^{106}$

103 Award, supra note 1, at paras. 353-54. Indeed, it is notable that the Tribunal itself preferred the "more recent Chinese chart" (Chart No. 1840o), based upon Chinese surveys between 1989 and 2001, to historical survey materials when concluding that McKennan Reef is a high tide feature.

104 Id. at paras. $378,381$.

105 Id. at para. 309.

106 Duncan French, In the Matter of the South China Sea Arbitration: Republic of Philippines, 19(1) Environmental Law Review 48, 52 (2017). 
The Tribunal's conclusions as regards the legal classification of these small features therefore warrant close attention.

The Tribunal's conclusion that Mischief Reef is a low-tide elevation, and is thus incapable of appropriation and cannot generate any maritime entitlements (Tribunal merits dispositive nos. 3(c) and 4), is open to serious doubt from a legal and evidentiary perspective. The Tribunal had significant evidence before it that Mischief Reef is a high tide feature. It noted that a detailed survey and chart of the feature prepared by H Ms Herald in 1933 refer to there being "a rock which dries 5 feet" on the south-east corner of the feature. ${ }^{107}$ The Tribunal referred also to Chinese Chart No. 1850o, which depicts the same rock at a height of 1 metre above "Mean Sea Level".108 The Tribunal noted that "either measurement would at least be close to the expected level of high water".09 In doing so, it acknowledged that both the historic British survey and more modern Chinese evidence support the existence of a high tide feature at Mischief Reef.

The Tribunal's assessment of the potentially dispositive nature of the 1933 survey evidence and Chinese Chart No. 18500 appears correct, given its own observation earlier in the Award that "the average range between Higher High Water and Lower Low Water for tides in the Spratlys is in the order of 0.85 metres, increasing to 1.2 metres during certain periods of the year. ${ }^{110} 5$ feet is substantially more than $\mathbf{1 . 2}$ metres. The Tribunal also noted that "the legend to the symbology for standard Chinese cartography indicates that Chinese charts will depict a rock or islet as one which does not cover if it exceeds the level of Mean High Water Springs", and that Mean High Water Springs would be an appropriate approximation of "high tide" if determined on the basis of Chinese nautical charts. ${ }^{111}$ On this rationale, the Tribunal could certainly have concluded from Chinese Chart No. 18500 that Mischief Reef is a high tide feature.

The Tribunal's finding that Mischief Reef is a low-tide elevation notwithstanding the 1933 survey evidence and Chinese Chart No. 18500 arguably contradicts its findings in relation to other features on the basis of comparable evidence. For example, the Tribunal concluded that Gaven Reef (North) is a high tide feature, observing that Japanese and US records from the 193os demonstrated the existence of a sand cay rising to a height of 1.9 metres on that

\footnotetext{
107 Award, supra note 1, at para. 374, citing to HMs Herald, Report of Visit to Mischief Reef, uкно Ref. H3331/1933.

108 Id. at para. 377 .

109 Id.

$110 \quad I d$. at para. 316.

111 Id. at para. 313.
} 
feature and noting that such a height would be "well above even Mean High Water Springs".12 The Tribunal similarly concluded with respect to Johnson Reef that it is a high tide feature, based upon (inter alia) a detailed survey and chart prepared by HMs Herald in 1931 showing a 4 foot rock in the south-east corner of the feature, together with Chinese Chart No 18400, which depicts a rock rising to $0.9 \mathrm{~m}$ above Mean Sea Level. ${ }^{113}$

Taken individually, there was a strong argument that Mischief Reef is a high tide feature in its natural form. However, the Tribunal reached the opposite conclusion, observing that it did not have "direct evidence of tidal conditions at Mischief Reef", and that the reference to "drying rocks" in the HMS Herald survey materials, and to the rocks being exposed "during half-tide" in the 2011 edition of the Chinese Sailing Directions, indicated that the rock was submerged at high tide, and thus that Mischief Reef is a low-tide elevation. ${ }^{114}$

This conclusion is open to serious question given the Tribunal's reliance elsewhere in the Award on Royal Navy survey and chart evidence and Chinese charts, its observations about the limited tidal range in the South China Sea, and its conclusion that, due to advances in satellite navigation, modern sailing directions are "less descriptive of the features on reefs and correspondingly less useful" than more historic evidence. ${ }^{115}$

The Tribunal could therefore have concluded that Mischief Reef is a high tide feature and is thus capable of appropriation and entitled at least to a territorial sea under UNCLOS. The argument that Mischief Reef is a rock under Article 121(3) of UNCLOS would be even stronger if contemporaneous evidence were available to demonstrate that the rock concerned remains above water at high tide. Had the Tribunal reached this conclusion, it would have concluded that it had no jurisdiction in respect of Philippines Submission nos. 5, 8, 9, 12 (so far as they concerned Mischief Reef and its territorial sea), and would thus have been unable to reach a number of its substantive findings on the merits (particularly dispositif nos. 7, 10, 14 and 16(a) and (d), as they relate to Mischief Reef).

By contrast, the Tribunal's conclusion that Second Thomas Shoal is also a low-tide elevation, and is thus incapable of appropriation and cannot generate any maritime entitlements (Tribunal merits dispositive nos. 3(c) and 4), appears to accord with the evidence before it. In particular, the Tribunal referred to a Royal Navy survey in the 1930s, Chinese Chart No. 18500 and the

\footnotetext{
112 Id. at para. 364 .

113 Id. at paras. $344-51$.

114 Id. at paras. $377-78$.

115 Id. at para. $33^{2}$.
} 
2011 edition of the Chinese Sailing Directions as demonstrating the absence of any high tide feature. ${ }^{116}$ We see no basis on which to challenge this conclusion.

3.2 .2

The Tribunal's Conclusions that Subi Reef, Gaven Reef (South) and Hughes Reef are Low-Tide Elevations (Philippines Submission Nos. 4 and 6; Tribunal Merits Dispositif No. 5)

The Tribunal concluded that Hughes Reef is a low-tide elevation, based in part upon the fact that it does not appear as a high tide feature on Chinese Chart No. 18400.117

The Tribunal concluded that Gaven Reef (South) is a low-tide elevation, based in part upon the 2011 edition of the Chinese Sailing Directions. ${ }^{118}$

The Tribunal concluded that Subi Reef is a low-tide elevation, based upon the absence of any evidence suggesting the existence of a high tide feature at that location. ${ }^{119}$

On the evidence that was before the Tribunal, we see no basis on which to challenge these conclusions. This is, of course, without prejudice to China's claims to sovereignty over the Spratly Islands and their adjacent waters as a "comprehensive whole". 120

3.2.3 The Tribunal's Conclusions that Scarborough Shoal, Gaven Reef (North) Mckennan Reef, Johnson Reef, Cuarteron Reef, and Fiery Cross Reef, in Their Natural Condition, are High Tide Features (Philippines Submission Nos. 3, 6 and 7; Tribunal Merits Dispositif No. 3)

The Tribunal's conclusions that the remaining features remain above water at high tide appear to have a sound legal and evidentiary basis, including (as regards some of the features) with reference to the 2011 edition of the Chinese Sailing Directions ${ }^{121}$ and Chinese Chart No. $18400 .{ }^{122}$ We note that the Tribunal's conclusions as regards the status of McKennan Reef and Gaven Reef (North) contradicted the Philippines' position that those features were low-tide elevations, the former based in large part upon Chinese Chart No. $18400 .{ }^{123}$ We see no basis on which to challenge any of these conclusions.

\footnotetext{
116 Id. at paras. $379-81$.

117 Id. at para. $35^{8}$.

$118 I d$. at para. 366 .

$119 I d$. at para. 373 .

$120 \quad I d$. at paras. $658-59$.

$121 I d$. at paras. 333,341

122 Id. at para. $35^{\circ}$.

123 Id. at paras. 354,365 .
} 


\section{The Tribunal's Classification of the Remaining Features in the} South China Sea as "Rocks" Generating No EEZ or Continental Shelf Entitlement under Article 121(3) of UNCLOS (Philippines Submission Nos. 3, 5 and 7)

The Tribunal turned next to the question of the status of the high tide features in the South China Sea under Article 121 of UNCLOS. It concluded that all of the relevant features constitute "rocks" generating no EEZ or continental shelf under Article 121(3).

The Tribunal's findings that none of the high tide features in question were islands within the meaning of Article 121 were a further pre-requisite for the Tribunal's jurisdiction in respect of Philippines Submission nos. 5, 8, 9 and 12, and for a number of its substantive findings on the merits (particularly dispositif nos. 7, 8, 9, 10, 14 and 16(a) and (d)). This is of particular relevance in the case of Itu Aba, which the Tribunal concluded was a "rock" pursuant to Article 121(3). Had the Tribunal found that Itu Aba was a fully-entitled island under Article 121(2), its EEZ would extend to include Mischief Reef, which is only 74 nautical miles $(\mathrm{nm})$ from Itu Aba. The Tribunal itself acknowledged that, in order that it could make a declaration in line with the Philippines Submission no. 5 (that Mischief Reef and Second Thomas Shoal are part of the EEZ and continental shelf of the Philippines), it must make "a finding that none of the Spratly Islands are fully entitled islands under Article 121".124 Similarly, it would have to conclude that the Spratly Islands cannot be regarded as one integral island group generating maritime entitlements.

The Tribunal's conclusions as regards the legal classification of the South China Sea features under Article 121 therefore warrant close attention.

Stance on the Importance of Article 121(3)" by Reference to Its Position on Oki-No-Tori-Shima

Notwithstanding China's absence from the proceeding, the Tribunal attempted to discern China's position on the meaning of Article 121 of UNCLOS. ${ }^{125}$ However, it did so exclusively with reference to China's recorded protests and other responses to Japan's November 2008 a claim of an extended continental shelf from Oki-no-Tori-Shima. ${ }^{126}$ In particular, the Tribunal referred

\footnotetext{
124 Id. at para. 399 .

125 Id. at paras. $446-72$.

$126 \quad I d$. at para. 451.
} 
to China's statements that Oki-no-Tori-Shima is a "rock" for the purposes of Article $121(3) \cdot{ }^{127}$

The Tribunal's assumptions as regards China's position on the interpretation of Article 121, and its insinuation that such position might be transferable to the context of the Spratly Islands and the South China Sea, are legally dubious.

First, it is clear that China's statements as regards the legal status of Oki-no-Tori-Shima are limited to the unique circumstances of that feature. ${ }^{128}$ They are not transferable as a matter of insinuation to the entirely different circumstances of the Spratly Islands. As Professor Talmon has observed, "no conclusions can be drawn from China's position on Oki-no-Tori-Shima for the legal status of larger maritime features in the South China Sea."129

Second, the physical and other characteristics of Oki-no-Tori-Shima are clearly distinguishable from those of the Spratly Islands, both individually and collectively. Oki-no-Tori-Shima has been described as "two coral protrusions no larger than king-size beds". ${ }^{130}$ It has a land area of less than $0.01 \mathrm{~km}^{2}$, while Itu Aba alone has a land area of $0.4639 \mathrm{~km}^{2}$. This makes Itu Aba nearly fifty times larger than Oki-no-Tori-Shima in its natural form. Furthermore, Itu Aba has a long record of human population and the presence of potable water and other criteria identified by the Tribunal as relevant to determination of whether a feature is a rock or a fully-fledged island under Article 121. By contrast, Oki-no-Tori-Shima fulfils none of those criteria.

\subsubsection{The Tribunal's Approach to Interpretation of Article 121}

The Tribunal set out its approach to the interpretation of Article 121 at paragraphs 476 and 477 of the Award. Notably, however, the Tribunal failed to recognise the fundamental distinction under the VCLT between the basic rule of interpretation under Article 31 and supplementary means of interpretation under Article 32. A leading international law commentary provides that:

The application of the basic rule of interpretation laid down in Article 31 of the Vienna Convention will usually establish a clear and reasonable meaning: if such is the case, there is no occasion to have recourse to other [i.e., supplementary] means of interpretation. ${ }^{131}$

\footnotetext{
127 Id., quoting from Note Verbale from the People's Republic of China to the SecretaryGeneral of the United Nations, No. CML/2/2009 (6 February 2009) (Annex 189).

128 Id.

129 Talmon, supra note 33, at 82.

130 Id.

131 Robert Jennings \& Arthur Watts, Oppenheims's International LaW, Part 2 to 4 , 1275-76 (9th, 2008).
} 
This approach was reinforced by the seminal Lotus Case (which predates the codification of treaty interpretation rules), in which the PCIJ held that:

The Court must recall in this connection what it has said in some of its preceding judgments and opinions, namely, that there is no occasion to have regard to preparatory work if the text of a convention is sufficiently clear in itself. 132

Similarly, in an Advisory Opinion rendered in 1950 in the Admissions case, the ICJ explained:

... the first duty of a tribunal which is called upon to interpret and apply the provisions of a treaty, is to endeavour to give effect to them in their natural and ordinary meaning in the context in which they occur. If the relevant words in their natural and ordinary meaning make sense in their context, that is an end of the matter. ${ }^{133}$

The ICJ elaborated that:

When the Court can give effect to a provision of a treaty by giving to the words used in it their natural and ordinary meaning, it may not interpret the words by seeking to give them some other meaning. In the present case the Court finds no difficulty in ascertaining the natural and ordinary meaning of the words in question and no difficulty in giving effect to them. Some of the written statements submitted to the Court have invited it to investigate the travaux préparatoires of the Charter. Having regard, however, to the considerations above stated, the Court is of the opinion that it is not permissible, in this case, to resort to travaux préparatoires. ${ }^{134}$

Article 32 lists travaux préparatoires as a supplementary source of interpretation, to be used when the meaning of the text is ambiguous or obscure, or

\footnotetext{
132 S.S. Lotus (Fr. v. Turk.), Judgment, 1927 P.C.I.J. (ser. A) No. 10, at 6 (Sept. 7).

133 Competence of the General Assembly for the Admission of a State to the United Nations, 1950 I.C.J. Rep. 8 (Advisory Opinion).

134 Id. We note that in the Fisheries Case, the I.C.J. held that because of the non-participation of one of the parties, it would "undertake a brief review of the negotiations that led up to [the provision in question]". However, the circumstances in that case were clearly distinguishable because it concerned the interpretation of a compromissory clause set out in an exchange of notes between two States, one of which was not present. Fisheries, supra note 38 , at 11 .
} 
where applying Article 31 would lead to a manifestly unreasonable result. ${ }^{135}$ Article 32 provides that travaux préparatoires may also be relied upon "in order to confirm the meaning resulting from the application of Article 31."

The Tribunal incorrectly relied on Article 32 by stating that that "recourse may be had to preparatory work of the treaty to confirm its meaning", 136 without adding that this can only be done in order to "confirm any meaning resulting from the application of Article 31". This is confirmed by the pre-VCLT jurisprudence of international courts and tribunals. ${ }^{137}$

The Tribunal proceeded to adopt a different approach, determining that, alongside the text, context and object and purpose of UNCLOS under Article 31, it would consider the travaux préparatoires under Article 32, as if both were of equal legal weight. ${ }^{138}$

The Tribunal's approach to the interpretation of Article 121, and partial reliance upon the travaux préparatoires of UNCLOS in particular, was thus, in our view, inconsistent with the rules of interpretation of treaties is contained in the VCLT.

Of additional note, Article 33 of the VCLT provides that "[w]hen a treaty has been authenticated in two or more languages, the text is equally authoritative in each language, unless the treaty provides or the parties agree that, in case of divergence, a particular text shall prevail". UNCLOS, Article 320 declares the Arabic, Chinese, English, French, Russian and Spanish texts to be equally authentic.

As pointed out by one commentary, the Tribunal failed to make any reference to the non-English language versions of UNCLOS, each of which is equally

135 See, e.g., Ris, Martin, Treaty Interpretation and I.C.J. Recourse to Travaux Preparatoires: Towards a Proposed Amendment of Articles 31 and 32 of the Vienna Convention on the Law of Treaties, 14(1) Boston College International and Comparative LaW Review, 118, 130-31 (1991).

136 Award, supra note 1, at para. 476.

137 See, for example, the Employment of Women During the Night Case (1932), PCIJ, Series A/B, No. 50, p. 380, where the Court found that "The preparatory work thus confirms the conclusion reached on a study of the text of the Convention [of Berne] that there is no good reason for interpreting Article 3 otherwise than in accordance with the natural meaning of the words". Similarly, the I.C.J. found that "the history of the Article [28(a) of the Convention for Establishment of Inter-Governmental Maritime Consultative Organisation] and the debate which took place upon the drafts of the same (...) confirms the principle [derived from the text]", the Constitution of the Maritime Safety Committee of the Inter-Governmental Maritime Consultative Organization, 196o I.C.J. Rep. 150 (June 8) (Advisory Opinion) at 161.

138 Award, supra note 1, at paras. 476-77. 
authoritative. ${ }^{139}$ UNCLOS does not accord priority to any one language version. As that commentator points out, it is often the case that "the precise meaning of a term in a multilingual text can only be established if the meaning of the term in all authentic languages is established."140

The Tribunal therefore erred in not making any reference to the other language versions of Article 121 in its interpretative exercise, notwithstanding the nuances of the English language text. Where relevant, this memorandum indicates other language texts that may cast doubt on the Tribunal's interpretation of Article $121 .^{141}$

\subsubsection{3}

The Tribunal's Interpretation of the Ordinary Meaning of Article 121(3) of UNCLOS

The Tribunal addressed six separate textual elements of Article 121(3), including (a) "rocks"; (b) "cannot"; (c) "sustain"; (d) "human habitation"; (e) "or"; and (f) "economic life of their own". ${ }^{142}$ This memorandum therefore addresses each in turn.

\subsubsection{1 "Rocks"}

As regards "rocks", the Tribunal concludes, correctly in our view, that the term does not impose fixed geological or geomorphological limitations so as to require a feature to be composed of solid rock or otherwise to be of a rock-like nature. ${ }^{143}$ However, the Tribunal does not give any indication of why Article 121(3) adopts the term "rocks", in contrast to the reference elsewhere in

139 Gerhard Hafner, Some Remarks on the South China Sea Award: Itu Aba Versus Clipperton, 34 Chinese (Taiwan) Yearbook of International Law and Affairs 1, 5-6 (2016).

140 Id.

141 French: "Les rochers qui ne se prêtent pas ál'habitation humaine ou á une vie économique propre n'ont pas de zone économique exclusive ni de plateau continental." [Literal translation: Rocks which do not lend themselves to human habitation or an economic life of their own do not have an exclusive economic zone or continental shelf.]; Spanish: "Las rocas no aptas para mantener habitación humana o vida económica propia no tendrán zona económica exclusiva ni plataforma continental." [Literal translation: The rocks which are not suitable to maintain human habitation or economic life of their own shall have no exclusive economic zone or continental shelf.]; Russian: Скалы, которые не пригодны для поддержания жизни человека или для самостоятельной хозяйственной деятельности, не имеют ни исключительной экономической зоны, ни континентального шельфа." [Literal translation: Rocks which are not suitable for sustaining human life or for independent economic activities shall have no exclusive economic zone or continental shelf.]

142 Award, supra note 1, at para. 478.

143 Id. at paras. $479-82,540$. 
the provision to "islands". Rather, the Tribunal proceed on the basis that there is no meaningful distinction between the two terms.

This is highly questionable as a matter of interpretation. The distinction between "rocks" and "islands" is repeated across all six original language versions of the Convention. While there are no records of the discussions of the "informal consultative group" which came up with the "rocks" wording in Article $121(3),{ }^{144}$ there is surely a reason why Article 121(3) refers to "Rocks which cannot sustain ..." rather than "Islands which cannot sustain ...".

However, the Tribunal did not consider this question. It simply observed in the Award that "repeated attempts during [the negotiation of UNCLOS] to define or categorise islands or rocks by reference to size were all rejected".145 While this may be true, this does not mean that the drafters of, and States Parties to, UNCLOS considered that there was no object of difference between "rocks" and "islands".

On the contrary, extensive evidence exists that the drafters and States Parties acknowledged that there must be a distinction between "rocks" and "islands", albeit perhaps more nuanced than a distinction based solely on size.

During the deliberations of the topic "regime of islands" in the Second Committee of the Third United Nations Conference on the Law of the Sea, States clearly distinguished between "islands", "islets", "rocks", and "low-tide elevations". In a draft article on the regime of islands proposed by 15 African States in August 1974, a "rock" was defined as "a naturally formed rocky elevation of ground", while an island or an islet was defined as a "naturally formed area of land." 146 Similarly, an informal proposal submitted by Ireland on behalf of nine States defined a "rock" as "a naturally formed rocky elevation normally unfit for human habitation." 147 This proposal was submitted on 25 April 1975 to the Second Committee's informal working group on the regime of islands. This

\footnotetext{
144 Id. at para. 531 .

145 Id. at para. 538.

146 See Unclos III, Algeria, Dahomey, Guinea, Ivory Coast, Liberia, Madagascar, Mali, Mauritania, Morocco, Sierra Leone, Sudan, Tunisia, Upper Volta and Zambia: draft articles on the regime of islands, UN Doc. A/CONF.62/C.2/L.62/Rev.1, 27 August 1974, OfFiciaL Records of the Third United Nations Conference on The LaW of the Sea, VoL. III, 232-33.

147 Renate Platzöder (ed.), Third United Nations Conference on the Law of the Sea: Documents, Vol. IV, 221-22 (1983). For the history of this proposal, see Mahon Hayes, The LaW of the Sea: The Role of the Irish Delegation at the Third UN Conference, 61-63 (2011). See also Romania's argument in Maritime Delimitation in the Black Sea (Rom. v. Ukr.), 2009 I.C.J. Rep. (Feb. 3) (Judgment), at para. 180, that 'Serpents' Island qualifies as a 'rock' because: it is a rocky formation in the geomorphologic sense."
} 
widely overlooked proposal clearly distinguished between "islets and islands" on the one hand and "rocks" on the other. ${ }^{148}$

This proposal was strongly opposed by States with offshore islands, in particular the Pacific Ocean small island States and New Zealand which argued that there was no logical reason to distinguish between sovereign rights appertaining to islands and sovereign rights appertaining to other land territory. In addition, they argued that all islands comprising the State must be treated alike and should have the same ocean space as other territories. ${ }^{149}$

In a paper entitled "Islands: Normal and Special Circumstances" that had been widely circulated at the 1973 Geneva session of the United Nations Committee on the Peaceful Uses of the Sea-Bed and the Ocean Floor Beyond the Limits of National Jurisdiction, Robert D. Hodgson, the Geographer of the U.S. State Department, suggested a categorization of islands by size. Hodgson distinguished between "(1) rocks, less than .001 square mile $\left[0,0025 \mathrm{~km}^{2}\right]$ in area; (2) islets, between .oo1 and 1 square mile $\left[2,589 \mathrm{~km}^{2}\right]$; (3) isles, greater than 1 square mile but not more than 1,00o square miles [2,589.99 $\left.\mathrm{km}^{2}\right]$; and (4) islands, larger than 1,000 square miles." ${ }^{150}$ The Soviet Union in June 1975 defined "small islets" as less than $0.1 \mathrm{~km}^{2}$ and "rocks" as less than $0.01 \mathrm{~km}^{2}$. In exchanges with the United States Government, the Russian Government took the position that islets or rocks below $0.1 \mathrm{~km}^{2}$ of land area should generate no continental shelf or economic zone. The prime example of a high-tide feature that would fall under Article 121(3) UNCLOS mentioned during the negotiations was the United Kingdom's "Rockall" - a tiny geological rock in the North Atlantic Ocean with a size of $0.000624 \mathrm{~km}^{2} .151$

148 Platzöder (ed.), supra note 147, at 222. For example, Article IV provided: "1. Islets or islands without economic life and unable to sustain a permanent population shall have no marine space of their own. 2. Rocks and low-tide elevations shall have no marine space or their own."

149 UNCLOS III, Second Committee, 39th Meeting, UN Doc. A/CONF.62/C.2/SR.39, 14 August 1974, Official Records of the Third United Nations Conference on the LAW OF THE SEA, Vol. II, 282, at para. 37 (Tonga).

150 Robert D. Hodgson, Islands: Normal and Special Circumstances, in John King Gamble Jr. and Giulio Pontecorvo (eds.), Law of the Sea: The Emerging Regime of the Oceans, Proceedings Law of the Sea Institute Eighth Annual Conference, June 18-21, 1973, 137, 150-51.

151 See, for example, Law of the Sea Conference: The Overall Prospects, Memorandum by the Minister of State for Foreign and Commonwealth Affairs [January 1975], British National Archives, CAB 148/149/14, LAW of the Sea Conference: Report on Third Session, Geneva, March - May 1975 . 
The drafting history, therefore, clearly shows that States considered the term "rocks" not to include "islets", let alone larger islands. ${ }^{152}$ Professor Talmon concludes that " $t$ t $]$ he drafters of Article 121(3) UNCLOS considered geology and size determinative of the status of high-tide features". 153

Academics also widely conclude that there must be a difference between "rocks" and "islands" for the purposes of Article 121. For example, Professor Alex Oude Elferink, who is a leading Dutch law of the sea academic and counsel, (in his JCLOS blog) interprets the term as imposing some size limitation on the features encompassed by Article 121(3).154

Professor Talmon presents a different, more nuanced, assessment. He observes that the Tribunal effectively "gave up the distinction between rocks and islands." ${ }^{155} \mathrm{He}$ continues:

The distinction in Article 121(3) UNCLOS is [...] not between islands that can sustain human habitation or economic life of their own and those that cannot, as held by the Arbitral Tribunal, but between rocks that can or cannot sustain human habitation or economic life of their own and all other islands, irrespective of their capacity for human habitation or economic life of their own. This means that there are three categories of islands:

(1) rocks that cannot sustain human habitation or economic life of their own;

(2) rocks that can sustain human habitation or economic life of their own; and

(3) all other islands.

Only the first category does not generate an EEz or continental shelf. ${ }^{156}$ Therefore, Professor Talmon concludes that the decisive question under Article 121(3) is not whether a feature qualifies as a "rock". However, an assessment of whether or not a particular feature is a "rock" is a critical first part of the application of that provision because, if a feature is not a "rock but an "island", Article 121(3) cannot apply. As he puts it, if a feature cannot be

\footnotetext{
$15^{2}$ Talmon, supra note 33, at 8 o.

153 Id.

154 Alex G. Oude Elferink, The South China Sea Arbitration's Interpretation of Article 121(3) of the LOSC:A Disquieting First, BLOG OF THE K.G. JebSEN CENTRE FOR THE LAW OF THE SEA (September 2016), 2-4.

155 Talmon, supra note 33 , at 76 .

156 Id. at 81 .
} 
considered a rock due to its geomorphology and size, "the follow up questions of its capacity to sustain human habitation or economic live of its own do not even arise". 157

Conversely, Professor Soons, one of the arbitrators on the Tribunal in the South China Sea arbitration, suggests in an article co-authored in 1990 with Barbara Kwiatowska that:

it would have been more appropriate if that paragraph [Article 121(3)] had simply referred to 'islands' and not 'rocks'. As the term 'rocks' should be construed as not implying any specific geological features, the essential element of the definition is [...] that it covers only rocks (islands) 'which cannot sustain human habitation or economic life of their own.158

Professor Sean Murphy concludes (correctly, in our view) that:

in asserting that the term "rock" conveys no geological or geomorphological meaning, and further that it conveys no meaning as to size, the tribunal seems to ascribe no significance whatsoever to the use of the word "rock" rather than "island" in paragraph 3. Given that the tribunal saw considerable significance in the precise wording of Article 121 in various other respects, the lack of attention to why the word "rock" was used in paragraph 3 is striking. ${ }^{159}$

In conclusion, the Tribunal's assimilation of the terms "islands" and "rocks" for the purposes of its interpretation of Article 121 is subject to serious doubt. As well as ignoring the adoption of markedly different language in the text of the provision, it is also undermined by the negotiating records of the Third UNCLOS Conference, which demonstrate a widespread appreciation that the terms "rocks" and "islands" mean different things. ${ }^{160}$ It is an accepted interpretative principle that the use of different terms in the same treaty provision indicate that they mean different things. As Oppenheim notes, "the use of similar but different terms, or a change in terminology from an earlier text, may be presumed to involve dissimilar meanings". ${ }^{161}$

\footnotetext{
157 Id.

158 Kwiatowska and Soons, supra note 8, at 153.

159 Sean D. Murphy, International Law Relating to Islands 94-95 (2017).

160 In this context, reference to the travaux préparatoires would have been entirely proper, as confirming the ordinary meaning of terms the purposes of Article 32 of the VCLT.

161 See Jennings and Watts, supra note 131, at 1273, n. 12 (citing Certain Expenses of the UN, 1962 I.C.J. Rep. at 159). See also Simon v. Court of Justice of the European Communities, 1961 I.L.R. 32 at 124 .
} 
Moreover, the distinction between "rocks" and "islands" is recognised in State practice. Consequently, a number of remote, uninhabitable but comparatively large island features around the world are universally recognised as generating EEZ rights under Article 121(2) of the UNCLOS. For example, Jan Mayen (Norway) Kiritimati (or Christmas Island, which is part of Kiribati) and Clipperton Island (France) are all comparatively large features lacking many of the "principal factors" (such as potable water) that the Tribunal identified as contributing "to the natural capacity of a feature" the purposes of Article 121(3). Nevertheless, all of those features are widely recognised as generating EEZ rights under Article 121(2) and are thus not considered to constitute "rocks" under Article 121(3). The most obvious reason for this is that the features are not "rocks" at all, with the result that Article 121(3) cannot apply.

This is the first respect in which the Tribunal's approach arguably contradicts the basic rules of treaty interpretation under the vCLT. Had the Tribunal considered, for example, its size and geology or geomorphology as part of a distinction between "rocks" and other "islands", it could have concluded that Itu Aba is not just a "rock", such that it falls outside Article 121(3). Notably, Itu Aba is substantially larger than any of the features that are universally recognised as "rocks" for purposes of Article 121(3). Furthermore, from a geological or geomorphological perspective, it is clear that Itu Aba is not the type of "rocky elevation" referenced by a number of States during the negotiation of Part VIII of UNCLOS in the context of the "regime of islands".

\subsubsection{2 "Cannot"}

As regards "cannot", the Tribunal concluded, correctly in our view, that the word "indicates a concept of capacity", being concerned with "whether, objectively, the feature is apt, able to, or lends itself to human habitation or economic life", and that "historical evidence of human habitation and economic life in the past may be relevant for establishing a feature's capacity".162 The Tribunal emphasised that this is an "objective criterion". ${ }^{163}$ This interpretation is also consistent with the remaining five authoritative language versions of Article 121(3). ${ }^{164}$

162 Award, supra note 1, at paras. $483^{-84}, 541$.

163 Id. at para. 545. Professor Sean Murphy concurs that the words "cannot sustain" "appear to speak to the objective ability of the feature to sustain human habitation or economic life, rather than whether the feature is actually doing so at any given time". See Murphy, supra note 159 , at 79 .

164 French: the French version states "Les rochers qui ne se prêtent pas à ...", which translates as "rocks which do not lend themselves to human habitation". This is consistent with the Tribunal's interpretation of lack of capacity; Spanish: The Spanish version is consistent with the Tribunal's interpretation of the term "cannot" as an objective criterion in its 
However, when it came to applying the "capacity" criterion to the features in the South China Sea, the Tribunal arguably contradicted its finding that the word "cannot" relates only to an objective concept of "capacity". This is discussed below in connection with the Tribunal's interpretation of the word "sustain".

\subsubsection{3 "Sustain"}

As regards "sustain", with reference to the Oxford English Dictionary the Tribunal identified three components: (i) "the concept of the support and provision of essentials"; (ii) a "temporal concept", entailing support and provision that is not one-off or short-lived; and (iii) a "qualitative concept", entailing at least a minimal "proper standard". 165

Of these, components (i) and (ii) are relatively uncontentious. However, component (iii), which introduces a "qualitative" element of sustainability, imposes a substantial additional threshold that results in more substantial island features being treated as "rocks" under Article 121(3).

According to the Oxford English Dictionary, the term "sustain" is defined, inter alia, as "[s]trengthen or support physically or mentally", "[c]ause to continue for an extended period or without interruption" and "[u]phold, affirm, or confirm the justice or validity of". The definition in itself does not generally include any "qualitative" element. On the contrary, used in connection with sustaining a person, the Oxford English Dictionary provides that sustain means to "maintain [...] in life and health; to provide with food, drink and other substances necessary for remaining alive; to feed, to keep."166 Nothing here implies that sustainability requires the attainment of any particular subjective "standard" of human habitation, beyond that necessary to maintain life and basic health.

Moreover, the question of whether support and provision reaches a "proper standard" is inherently subjective and, given the major advances in global living standards since 1982, liable to the imposition of higher thresholds today than at the time of negotiation of UNCLOS. This is difficult to reconcile with the Tribunal's (correct) observation elsewhere that the term "cannot" in

connection with "sustain". The word "no" is linked to "aptas", i.e. "no aptas", whereas in English is only "cannot". However, both sentences structures, "cannot" and "no aptas" are consistent as indicating an objective lack of capacity.

165 Award, supra note 1, at paras. 485-87.

166 The Oxford English Dictionary, definition of "sustain", on the oxford dictionary website at: https://en.oxforddictionaries.com/definition/sustain. 
Article 121(3) relates to the "objective capacity of the feature to sustain human habitation or economic life". 167

Notably, a number of the other official language versions of Article 121(3) undermine the Tribunal's conclusion of a "qualitative" aspect as part of its interpretation. ${ }^{168}$

The "qualitative" aspect of the Tribunal's interpretation of Article 121(3), combined with the requirement for the sustainability of a "stable community" referred to below, was determinative of the Tribunal's conclusion on the status of a number of the larger features, most obviously Itu Aba. ${ }^{169}$ However, that "qualitative" component arguably imposes a threshold to the attainment of fully-fledged "island" status that is unwarranted by the text, context and object and purpose of unclos. Further, the "qualitative" component is difficult to reconcile with the Tribunal's conclusion that the concept of "human habitation" might be met with respect to "a few individuals" in remote atolls (of which the Spratly Islands are clear examples), and by "periodic or habitual residence" (of which there is a long record in Itu Aba, particularly by fishing communities prior to UNCLOS). ${ }^{170}$

\subsubsection{4 "Human Habitation"}

As regards "human habitation", the Tribunal again started its interpretation with reference to the Oxford English Dictionary. However, it then introduced an additional, subjective element to the term, deciding that "the use in Article 121(3) of the term "habitation" includes a qualitative element". 171 The Tribunal stated that such an element "implies a non-transient presence

167 Award, supra note 1, at paras. 504(b), 545 .

168 French: according to the online Larousse dictionary "se prêter à" means, inter alia, "being suitable for an activity, being appropriate". Spanish: According to the "Dictionary of La Real Academia de la Lengua Espanola", the term, "mantener" (in English "maintain") has, inter alia, the following definitions: "to provide someone with the necessary food"; "to assume someone's financial needs"; "to keep something in its existence, to give it endurance and permanence". Thus, the French and Spanish versions do not seem to include any qualitative concept inherent to "sustain" (or "maintain" - which is the term used in Spanish). Rather, "maintain/sustain" relate more to a period of time (permanency) than a quality standard. Russian: According to the Official Dictionary of Russian language (available on the website "Gramota. Ru"), the term "поддержать" (in English "sustain" or "maintain") is defined as, inter alia, "to save the existence of smth" (e.g. "the existence of rare animals") or "keep [smth] in proper form, condition". Again, this does not imply a separate quantitative element.

169 Award, supra note 1, at paras. 618-22.

$170 \quad I d$. at para. 542.

171 Id. at para. 489 . 
of persons who have chosen to stay and reside on the feature in a settled manner". ${ }^{172}$ Furthermore, the Tribunal observed that the term "habitation" should also imply "habitation of the feature by a group or community of persons", in a "stable community" that "can fairly be said to constitute the natural population of the feature". ${ }^{13}$

Again, there is no textual basis in Article 121 for these "qualitative" elevations of the threshold for attainment of fully-fledged island status. While aspects of the Tribunal's findings are not unreasonable (for example, its observation that a community of persons "need not necessarily be large, and in remote atolls a few individuals or family groups could well suffice"), ${ }^{174}$ the insertion of additional requirement of "stable communities" and "natural populations" will inevitably lead to the classification of more substantial features as "rocks" for the purposes of Article 121(3). Indeed, if, as explained above, the term "rocks" in Article 121(3) must have its own meaning with reference to criteria such as geomorphology and size, then it may be difficult to conceive of a "rock" that could sustain a "stable community" or "natural population" up to the "qualitative" standards imposed by the Tribunal's interpretation.

A commentator observed that:

... it is not clear what the legal basis is for requiring "a group or community of persons" to establish habitation, as one simply cannot infer any such requirement from the text of Article 121. [...] If clearly one person does not make a group or community, will two or a few more do? Thus, it should be possible that even two persons can form such a "group or community of persons over sustained periods of time. ${ }^{175}$

The Tribunal's inclusion of a "qualitative" element in relation to each of the concepts of sustainability and human habitation deflects from the important fact that, as the Tribunal found elsewhere, Article 121(3) is concerned with the objective "capacity" of a feature to sustain human habitation. This should not require the actual existence of human "communities" or "populations", nor even the capacity to sustain substantial groups of people over long periods. The imposition of "qualitative" elements into its interpretation brought with it inherently subjective criteria that undermine the application of Article 121(3)

\footnotetext{
172 Id.

173 Id. at paras. $491,542$.

174 Id. at para. 542 .

175 Jiangyu Wang, Legitimacy, Jurisdiction and Merits in the South China Sea Arbitration: Chinese Perspective and International Law, 22(2) Journal of Chinese Political SCIENCE 185, 205 (2017).
} 
to small features that do not display permanent populations. Certainly, this was not the intention of the drafters of the Convention.

Moreover, similarly to the qualitative element read in by the Tribunal to the term "sustain", the Tribunal's reading of an additional "qualitative element" into the term "human habitation" is not supported by a number of the other official language versions of UNCLOS. ${ }^{176}$

\subsubsection{5 "Or"}

As regards "or", the Tribunal disagreed with the Philippines' argument that a capacity to sustain both human habitation and economic life are required in order for a feature to be a fully-fledged island, entitled to an EEZ and continental shelf. Instead, the Tribunal concluded that "if a feature is capable of sustaining either human habitation or an economic life of its own, it will qualify as a fully entitled island". 177 We agree with this conclusion.

As Professor Elferink observes:

The word "or" between "human habitation" and "economic life of their own" implies that these requirements do not have to be met at the same time. ${ }^{178}$

The drafting history of Article 121(3) further indicates that the requirements of human habitation and economic life were introduced as separate requirements. ${ }^{179}$

176 French: "Les rochers qui ne se prêtent pas ál'habitation humaine ou á une vie économique propre n'ont pas de zone économique exclusive ni de plateau continental." [Literal translation: Rocks which do not lend themselves to human habitation or an economic life of their own do not have an exclusive economic zone or continental shelf.]; Spanish: "Las rocas no aptas para mantener habitación humana o vida económica propia no tendrán zona económica exclusiva ni plataforma continental." [Literal translation: The rocks which are not suitable to maintain human habitation or economic life of their own shall have no exclusive economic zone or continental shelf.]; Russian: Скалы, которые не пригодны для поддержания жизни человека или для самостоятельной хозяйственной деятельности, не имеют ни исключительной экономической зоны, ни континентального шельфа." [Literal translation: Rocks which are not suitable for sustaining human life or for independent economic activities shall have no exclusive economic zone or a continental shelf.]

177 Award, supra note 1, at paras. 494-97, 544.

178 Elferink, supra note 154 , at 5-6.

179 See United Nations, Office for Ocean Affairs and the Law of the Sea, The LAw of ThE Sea: Régime of Islands: Legislative History of Part vili (Article 121) of the United Nations Convention on the LaW of the Sea 6o-7o (1988). 
Notably, the Tribunal also observed that island features may have capacity to sustain only human habitation or economic life, but not both, including in cases "where multiple islands are used in concert to sustain a traditional way of life". ${ }^{180}$ The Tribunal was "conscious that remote island populations often make use of a number of islands, sometimes spread over a significant distance, for sustenance and livelihoods". ${ }^{181}$ A commentator observed that:

... in practical terms the conditions will in fact be conjunctive. Nonetheless, the Award also details a possible exception in the case of populations sustaining themselves through a network of related maritime features. ${ }^{182}$

The Tribunal's findings in this respect may be particularly pertinent as regards the Spratly Islands, depending on the extent of evidence of any "traditional way of life" or pattern of sustenance across the islands by fisherfolk or otherwise in the past. Certainly, elsewhere in the Award, the Tribunal recognised the periodic inhabitation of the islands through history by Chinese and other fishing communities. ${ }^{183}$ However, as a result of the "qualitative" criteria mentioned above, the Tribunal did not consider such periods of inhabitation of the islands sufficient to retain the threshold for fully-fledged island status on the Article 121.

\subsubsection{6 "Economic Life of Their Own"}

As regards "economic life of their own", the Tribunal concluded that the phrase "presupposes ongoing economic activity", and "makes clear that the feature itself (or group of related features) must have the ability to support an independent economic life, without relying predominantly on the infusion of outside resources or serving purely as an object for extractive activities".

Charney strongly disagrees with this interpretation. Many years prior to the Award, he contended that the condition of "economic life" should be satisfied as long as a resource is exploited over "some period of time" and generates sufficient revenues to support all equipment and personnel. ${ }^{184}$ There is some force to this interpretation, particularly since the requirement of "economic

\footnotetext{
180 Award, supra note 1, at paras. 497, 544.

181 Id. at para. 547.

182 Lachlan McDermott, Philippines v. China-Rocks or Islands under International Law?, 36(1) University of TASMANia LaW Review 36, 57 (2017).

183 Award, supra note 1, at paras. 618-19.

184 Jonathan I. Charney, Rocks that Cannot Sustain Human Habitation, 93(4) AMERICAN JoURNAL OF INTERNATIONAL LAW 863, 870 (1999).
} 
life" must be interpreted disjunctively from the separate requirement of "human habitation" under Article 121(3).

Other commentators (e.g. Barbara Kwiatkowska, Alfred Soons, Oude Elferink and Jonathan Hafetz) have suggested that 'economic life' should be equated to 'economic value.' ${ }^{185}$ It has been observed that such an approach would mean that the requirement could be met with the mere presence of a lighthouse or economic viable maritime conservation areas. ${ }^{186}$

Along these lines, Professor Soons (one of the arbitrators in the South China Sea case) explained in a 1990 publication:

[w] hile in the past the idea that a radio or weather observation post qualified a rock as an island has been rejected, such a test seems at present to be acceptable. An increasing number of authors recognize that, for instance, a lighthouse or other aid to navigation built on an island (rock) gives a rock an economic life of its own in its value to shipping, ocean sports and so forth. If economic life need not be a commercial nature, why should rocks large enough to support a shelter (like Minerva Reefs), or used for guano harvesting (like Aves and Clipperton in the past), or rocks from which birds' eggs and turtles are collected not be considered as capable of sustaining economic life?187

Nevertheless, the Tribunal concluded that "distant fishermen exploiting the territorial sea surrounding a small rock and making no use of the feature itself [...] would not suffice to give the feature an economic life of its own". ${ }^{188}$

Certain elements of the Tribunal's conclusions as regards the meaning of "economic life of their own" in Article 121(3) are not open to substantial doubt. For example, its observation that the term implies "the ability to support an independent economic life" appears reasonable. However, as explained below, the Tribunal's subsequent application of these conclusions to the facts and

185 See Kwiatowska and Soons, supra note 8, at 167-168; Alex G. Oude Elferink, The Islands in the South China Sea: How Does Their Presence Limit the Extent of the High Seas and the Area and the Maritime Zones of the Mainland Coast?, 32(2) Ocean Development \& International LaW 169, 174 (2001); Jonathan L. Hafetz, Fostering Protection of the Marine Environment and Economic Development: Article 121(3) of the Third Law of the Sea Convention, 15(3) American University International Law Review 584, 623-627 (2000).

186 McDermott, supra note 182 , at $54-55$.

187 Kwiatowska and Soons, supra note 8, at 167-68.

188 Award, supra note 1, at paras. 498-503. 
evidence before it related to, in particular, Itu Aba, which has a long history of sustaining different economic activities, is highly questionable.

\subsubsection{4}

The Tribunal's Assessment of Context, Object and Purpose under Article 31 of the vCLT

The Tribunal proceeded to consider the context of Article 121(3) and the object and purpose of the Convention at paragraphs $507-520$ of the Award.

As an overarching point of context, the Tribunal's approach to the interpretation of Article 121(3) of UNCLOS ignored the context of that provision as a whole within Article 121. In particular, the Tribunal ignored the fact that the treatment of "rocks" under Article 121(3) is an exception to the general rule at Article 121(2) that islands generate full EEZ and continental shelf entitlements. As Professor Sean Murphy has observed:

[Articles 121(2) and (3)] were a compromise between those States who wished all islands to generate the full range of maritime zones and those States who wished to limit the ability of islands to do so. The compromise was to allow islands normally to generate the full range of maritime zones, but not in situations where the island is nothing more than a paragraph 3 "rock". 189

Professor Myron Norquist, who was Secretary of the US Delegation to the UNCLOS III Conference when Article 121 was drafted, similarly observes that Article 121(3) "was drafted as an exception to the first two paragraphs of Article 121 ". ${ }^{190}$ He observes, correctly in our view, that exceptions to general rules are generally construed strictly as a matter of treaty interpretation, particularly where such exceptions are explicit (as here, given the wording of Article 121(2)) and where the exception at Article 121(3) has the effect of curtailing the EEz entitlement of islands under the general rule. Professor Norquist concedes that "in cases of doubt, "rocks" should be presumed to be "islands" granted full maritime entitlement as land territory". 191

By contrast, in focusing its analysis on whether Itu Aba and other features can "sustain human habitation or economic life of their own" for the purposes of Article 121(3), the Tribunal effectively reversed the burden of proof under

189 Murphy, supra note 159 , at 76.

190 Myron H. Nordquist, UNCLOS Article 121 and Itu Aba in the South China Sea Final Award: a correct interpretation? in S. Jayakumar, Tommy Koh, Robert Beckman, Tara Davenport \& Hao D. Phan(ed.), The South China Sea Arbitration: The Legal Dimension 185 (2018).

191 Id. 
Article 121. This is because it assumed that, if the evidence did not positively prove the features' ability to "sustain human habitation or economic life of their own", those features must be treated as "rocks". As Professor Murphy continues:

The tribunal's approach in deciding the case almost seems to impose a burden of proving that an island does not fall within Article 121, paragraph 3, rather than the other way around. Such a burden seems inconsistent with the structure of Article 121, which presents paragraph 3 as an exception to a general rule that all islands are entitled to full maritime zones. ${ }^{192}$

The Tribunal concluded that "a rock cannot be transformed into a fully entitled island through land reclamation". 193 This conclusion follows from the text of Article 121(1), which requires any island to be a "naturally formed area of land".

The Tribunal also correctly described the purpose of the EEZ as being "to extend the jurisdiction of States over the waters adjacent to their coasts and to preserve the resources of those waters for the benefit of the population of the coastal State". 194

However, in a highly questionable passage, the Tribunal commented that Article 121(3) "serves to disable tiny features from unfairly and inequitably generating enormous entitlements to maritime space that would serve not to benefit the local population, but to award a windfall to the (potentially distant) State to have maintained a claim to such a feature". 195 Again, there is nothing in the text, object or purpose of UNCLOS to support such a broad-ranging political assertion.

Moreover, such an approach would have broad-ranging implications, casting into serious doubt the EEZ and continental shelf claims made by a number of "distant" States around "tiny features". 196 For example, France claims an E EZ around Tromelin, an island in the Indian Ocean more than 8,ooo km from

\footnotetext{
192 Murphy, supra note 159, at 94.

193 Award, supra note 1, at paras. 508-10. Professor Nordquist has expressed a different view on this point, to the effect that the Tribunal "erred" by requiring that the capacity of an island feature to sustain human habitation or economic life should be based upon the feature's "natural form". Nordquist, supra note 190, at 177-90.

194 Award, supra note 1, at para. 513.

195 Id. at para. 516.

196 For examples of such features, see Table 1, 'Features fully entitled under Article 121(2)', and Table 2, 'Features unilaterally entitled under Article 121(2)', in Annex 1 to this Critique.
} 
the mainland with an area of $0.8 \mathrm{~km}^{2}{ }^{197}$ Venezuela claims an EEZ around the much smaller feature of Isla Aves in the Caribbean Sea, which claim has been accepted by a number of States in delimitation agreements. ${ }^{198}$ Isla Aves has a land area of just $0.032 \mathrm{~km}^{2}$ and is generally uninhabited, other than a small scientific station and naval contingent. 199

The Tribunal's approach also ignores the separate question of the reduced weight that is often given to small island features in EEZ and continental shelf delimitation with continental States. The jurisprudence of the ICJ and arbitral tribunals consistently holds that very small island features may be accorded limited or no effect in EEZ or continental shelf delimitation, in order to avoid such features having a disproportionate effect in the delimitation. ${ }^{200}$ For example, in Newfoundland $v$. Nova Scotia, the tribunal gave half effect to Sable Island out to its 2oonm limit, "[h] aving regard to its remote location and the very substantial disproportionate effect this small, unpopulated island would have on the delimitation if it were given full effect". 201

The Tribunal then strayed into another highly questionable analysis, with reference to the remarks of a representative of Peru in the Seabed Committee, to the effect that EEz rights should not be applied "to more or less uninhabited islands, since its main justification lay not in the existence of a territory but in the presence of the population which inhabited it, whose needs should be satisfied through the use of the resources available in its environs". ${ }^{202}$ As a result, the Tribunal concluded that "taken together with notions of settlement and residence and the qualitative aspect inherent in the term habitation, it

197 See, e.g., Decree No. 78-146, 11 February 1978, Official Journal of the French Republic; and Decree No. 2007-1254, 21 August 2007, Official Journal of the French RePUblic, the United Nations, http://www.un.org/depts/los/LEGISLATION ANDTREATIES/PDFFILES/DEPOSIT/fra_mzn74_20o9.pdf.

198 See, e.g., the United States-Venezuela Agreement (1978), the Netherlands (Antilles)Venezuela Agreement (1978) and the Venezuela-France Agreement (1980).

199 See, e.g., Global Security Note on Aves Island, Globalsecurity.org, https://www.global security.org/military/world/caribbean/aves.htm. See also, Hafner, supra note 139, at 8-9.

200 See, e.g., Continental Shelf (Libya v. Malta), 1985 I.C.J. Rep. 13 (June 3) (Judgment) at para. 64; Maritime Delimitation and Territorial Questions, supra note 17, at 104, para. 219; Territorial and Maritime Dispute between Nicaragua and Honduras in the Caribbean Sea (Nicar. v. Hond.), 2007 I.C.J. Rep. 659 (Oct. 8) (Judgment) at para. 302; and Maritime Delimitation in the Black Sea, supra note 147 , at para. 185.

201 Arbitration between Newfoundland and Labrador and Nova Scotia concerning Portions of the Limits of their Offshore Areas, Award of the ad Hoc Tribunal in the second phase, 26 March 2002, at para. 5.13. See also Section 3.b below, which identifies other State practice that undermines the Tribunal's approach.

202 Award, supra note 1, at para. 518. 
should be understood to refer to the habitation of a feature by a settled group or community for whom the feature is a home". ${ }^{203}$ In doing so, the Tribunal again ignored the critical fact that Article 121(3) is concerned with the objective "capacity" of a feature to sustain human habitation or economic life, not the question of whether a feature is in fact inhabited, and whether or not there is in fact a group or community that calls the feature "home". Still less is there any prohibition against "more or less uninhabited islands" generating EEZ and continental shelf rights.

For example, the remote Norwegian island of Jan Mayen, which is a scientific outpost that has never had any permanent population, was accepted by Denmark and the ICJ in the Jan Mayen case as constituting an island that generates substantial EEZ and continental shelf rights for Norway. ${ }^{204}$ This is despite the fact that the feature is located in the Arctic Circle, in an isolated location. Indeed, in its Memorial in that case, Denmark described the feature as a desolate island without natural resources of any significance, referring to the fact that mining and hunting had been attempted there but abandoned, and describing an attempt to build a harbour as a fishing base that had similarly been abandoned. Other than its size $\left(373 \mathrm{~km}^{2}\right)$, it thus exhibits a number of features indicating less capacity than Itu Aba to sustain human habitation or economic life of its own. ${ }^{205}$ Nevertheless, at the hearing in the Jan Mayen case, Denmark accepted that Jan Mayen was not a rock but an island for the purposes of Article 121. ${ }^{206}$

As with its textual interpretation, in a number of respects the Tribunal's assessment of context, object and purpose under Article $3^{1}$ of the VCLT is therefore highly questionable. It had the inevitable effect of again raising the threshold to be met by any feature in order to be accorded fully-fledged

203 Id. at paras. $518-20$.

204 In its Judgment, the I.C.J. stated that "the attribution of maritime areas to the territory of a State, which, by its nature, is destined to be permanent, is a legal process based solely on the possession by the territory concerned of a coastline" and thus concluded that "there is no reason to consider either the limited nature of the population of Jan Mayen or socio-economic factors as circumstances to be taken into account". Maritime Delimitation in the Area between Greenland and Jan Mayen (Den. v. Nor.), 1993 I.C.J. Rep. 41 (June 14) (Judgment), at para. 8o.

205 For example, in his Separate Opinion, Judge Schwebel observed that "the singular characteristics of Jan Mayen Island may leave room for argument about whether it meets the standards of Article 121, but Denmark did not make that argument; it accepted that Jan Mayen Island is not a rock but an island". Maritime Delimitation in the Area between Greenland and Jan Mayen (Den. v. Nor.), 1993 I.C.J. Rep. 41 (June 14) (Separate Opinion of Judge Schwebel), at 126.

206 Id. 
island status under Article 121 of UNCLOS. Further, as observed by a number of commentators, ${ }^{207}$ it effectively reversed the burden of proof under Article 121(3) by imposing a presumption that a high-tide feature is a "rock" unless proven otherwise. As explained at Section III.B.(vi) and illustrated at Annex 1 below, the Tribunal's approach would have a substantial impact on State practice and ICJ jurisprudence that accords EEZ and continental shelf entitlements to features that appear no more capable than Itu Aba of meeting the requirements of Article 121.

\subsubsection{The Tribunal's Assessment of the Travaux Préparatoires of UNCLOS under Article 32 of the VCLT}

As explained above, the Tribunal moved on to consider the travaux préparatoires of UNCLOS, without indicating any legal basis for doing so as a supplementary means of interpretation under Article $3^{2}$ of the vCLt. The Tribunal simply stated that it considered that "further examination of the circumstances that led to the adoption of Article 121 is warranted for the light it sheds on the purpose of the provision itself". 208 This is not a valid reason for making reference to travaux préparatoires under the VCLT or customary international law.

The Tribunal's lengthy discussion of travaux préparatoires in its interpretation of Article 121(3), at paragraphs $5^{21-538}$ of the Award, is all the more remarkable given its acknowledgement that there are no existing records around the preparation of the final text by an informal consultative group at the Third UN Conference in 1975. Even the Tribunal acknowledged that the travaux préparatoires are an "imperfect guide" to interpretation of Article $121(3) .{ }^{209}$ Even if it was legitimate for the Tribunal to refer to the travaux préparatoires, they were therefore of limited value as an interpretive tool. ${ }^{210}$

The Tribunal nevertheless drew a number of conclusions from the travaux préparatoires to confirm its restrictive textual interpretation of Article 121(3). In particular, it considered that the travaux préparatoires show that Article 121(3) was intended to prevent "encroachment on the international seabed reserved

\footnotetext{
207 Murphy, supra note 159, at 94.

208 Award, supra note 1, at para. 521.

209 Id. at paras. 531, 534.

210 Jennings and Watts, supra note 131, at 1277, para. 633: "The value of preparatory work in shedding light on the meaning of a treaty will vary from case to case. Often the records of treaty negotiations are incomplete and do not adequately cover compromises arrived at during the final stages of a conference or those reached privately away from the negotiating table: the negotiating records inevitably relate to matters taking place before the final expression of the parties' intentions has been made."
} 
for the common heritage of mankind and of avoiding the inequitable distribution of maritime spaces under national jurisdiction". 211

Other aspects of the travaux préparatoires indicate caution against small, largely uninhabited islands in denied any EEz or continental shelf rights, particularly where those features or their surrounding waters comprise an important part of the economy of populations permanently located elsewhere. For example, Micronesia is recorded as having stated:

Suggestions have also been made that uninhabited islands should not have a full economic zone. Almost all of our high islands, and almost all of our atolls, made up of low islands, are inhabited. But some islands are inhabited only part of the year, while others are used not as residences but for fishing or in some functional way other than for permanent habitation. They are all the same as vital a part of our economy and livelihood as some islands that may have permanent dwellings on them, but may have little or no fish resources near them. We do not believe that the criteria of inhabitation or size are practical or equitable..$^{212}$

Moreover, the Article 121 classification of the Spratly Islands in the South China Sea, which is a semi-enclosed sea the vast majority of which falls within areas of national EEz/continental shelf jurisdiction in any event, does not risk material encroachment on deep sea-bed areas. Therefore, the concerns around protection of the "common heritage of mankind", highlighted by the Tribunal with reference to the travaux préparatoires, ${ }^{213}$ are less pertinent in the South China Sea than they are in areas of ocean space.

As far as "inequitable distribution of maritime spaces" is concerned, that is a matter for delimitation rather than a factor in the interpretation of entitlement under Article 121. After all, Articles 74 and 83 of UNCLOS provide for delimitation of the exclusive economic zone and continental shelf claims specifically in order to "achieve an equitable solution". Matters of delimitation fell squarely outside the jurisdiction of the Tribunal. The Tribunal's interpretation and application of Article 121(3) so as to "avoid inequitable distribution of maritime spaces under national jurisdiction", and thus to deprive the Spratly

\footnotetext{
211 Award, supra note 1, at para. 535.

212 Statement by the Chairman of the Joint Committee of the Congress of Micronesia submitted on behalf of the Congress by the United States of America, Official Records of the Third United Nations Conference on the Law of the Sea, UN Doc. A/CONF.62/L.6 (27 August 1974), the United Nations, http://legal.un.org/diplomaticconferences/1973_los/docs/ english/vol_3/a_conf62_l6.pdf.
}

213 Award, supra note 1, at para. 536, n. 574. 
Islands from generating any maritime entitlements beyond $12 \mathrm{NM}$, had the effect of improperly circumventing China's Article 298 declaration withdrawing matters of delimitation from the Tribunal's jurisdiction. As explained at Section III.B.(vi), there are many examples around the world of small island features being accorded limited weight in delimitation beyond $12 \mathrm{NM}$, thereby avoiding any "inequitable distribution". Indeed, the need to prevent a small island feature (Jan Mayen) from generating entitlements that would be "excessive and inequitable" vis-à-vis a large neighbouring landmass (Greenland) was an explicit basis for the ICJ's delimitation of a boundary closer to Greenland in the Jan Mayen case. ${ }^{214}$

Notably, in a 199o publication, Professor Soons, one of the arbitrators in the Arbitration, observed the practical inseparability between the legal definition of "rocks" under Article 121(3) of UNCLOS and considerations of equity in maritime boundary delimitation. ${ }^{215}$

In conclusion, the Tribunal's reference to the travaux préparatoires of Article 121 of UNCLOS and related materials was legally questionable, selective and contributed to the Tribunal's restrictive interpretation that is difficult to reconcile with the ordinary meaning of the text. As such, the Tribunal's interpretation of Article 121, and Article 121(3) in particular, is subject to serious doubt.

3.1.2

The Tribunal's Conclusion as Regards the "Principal Factors" that

Contribute to the Natural Capacity of a Feature for the Purposes of Article 121(3)

The Tribunal considered that the "principal factors that contribute to the natural capacity of a feature" include "the presence of water, food, and shelter in sufficient quantities to enable a group of persons to live on the feature for an indeterminate period of time". However, it observed that the relative contribution and importance of the various factors will vary from one feature to another. Accordingly, the Tribunal did not consider that "an abstract test of the objective requirements to sustain human habitation or economic life can or should be formulated". 216 We agree with these aspects of the Tribunal's findings.

\footnotetext{
214 Delimitation in the Area between Greenland and Jan Mayen, supra note 204, at para. 87.

215 Kwiatowska and Soons, supra note 8, at 146, para. 1.5.

216 Award, supra note 1, at para. 546.
} 
The Tribunal concluded that "the most reliable evidence of the capacity of a feature will usually be the historical use to which it has been put". ${ }^{217}$ Again, we agree with this conclusion. To the extent that evidence can be presented demonstrating a history of human habitation on any feature or connected group of features, including habitation that has been cut short by "intervening forces" such as warfare, that evidence should be dispositive of the status of the feature or features under Article 121.

Finally, we agree with the Tribunal's conclusion that "evidence of human habitation that predates the creation of exclusive economic zones may be more significant than contemporary evidence, if the latter is clouded by an apparent attempt to assert a maritime claim". 218 That conclusion is of clear relevance in the context of the Spratly Islands, a number of which display a long history of human habitation and economic activity that pre-dates the negotiation of UNCLOS.

The Tribunal's Conclusions that Scarborough Shoal, Johnson Reef, Cuarteron Reef, Fiery Cross Reef, Gaven Reef (North) and Mckennan Reef, in Their Natural Condition, are Rocks that Cannot Sustain Human Habitation or Economic Life of Their Own under Article 121(3) of UnCLOS (Philippines Submission Nos. 3, 6 and 7; Tribunal Merits Dispositif No. 6)

Having set out its approach to the interpretation of Article 121, the Tribunal turned to the application of that provision to the individual features raised by the Philippines in its Submission nos. 3 and 7, together with Gaven Reef (North) and McKennan Reef (each of which the Tribunal had found to be high tide features, contrary to The Philippines' Submission no. 6).

The Tribunal's conclusion that Scarborough Shoal, Johnson Reef, Cuarteron Reef, Fiery Cross Reef, Gaven Reef (North) and McKennan Reef, in their natural condition, were "rocks" for the purposes of Article 121(3) appears correct on the basis of the evidence before the Tribunal. We also agree with the Tribunal's conclusion that recent construction activities on these features, however extensive, cannot elevate their status from a rock to a fully-entitled island under Article 121.

\footnotetext{
217 Id. at para. 549.

218 Id. at para. $55^{\circ}$.
} 
The Tribunal turned to address certain Chinese statements to the effect that it enjoys exclusive economic zone and continental shelf rights based on the Spratly Islands "as a whole". 219

The Tribunal stated that, to the extent that China considers that the criteria of human habitation and economic life under Article 121(3) must be assessed with reference to networks of closely related maritime features, it agreed. In particular, it commented that Article 121(3) must not be applied "in a strictly atomised fashion" with respect to small island populations using groups of reefs or atolls to support their livelihood. We agree with this conclusion, which also reflects the comments made by Micronesia during the negotiation of UNCLOS, cited above.

The Tribunal continued that, to the extent that China asserts that the Spratly Islands can be enclosed within a system of archipelagic or straight baselines, according an entitlement to maritime zones as a single unit, it could not agree. This was because China is not an archipelagic State for the purposes of Article 46 of the Convention, and the limits imposed by Article 47 would prohibit the use of archipelagic baselines in any event. The Tribunal also commented that any application of straight baselines to the Spratly Islands would be contrary to UNCLOS and is, in effect, excluded by the combination of Articles 7,46 and 47 .

The Tribunal's findings that China is not an archipelagic State, that an archipelagic baseline around the Spratly Islands would not meet the criteria set for archipelagic States by Article 47 of UNCLOS, and that a straight baseline around the Spratly Islands could not be justified by reference to Article 7 of the Convention, although obiter dicta and absent from the Tribunal's dispositive findings, are correct.

However, notably, the Tribunal observed that UNCLOS does not expressly preclude the use of straight baselines in other circumstances. ${ }^{220}$ Further, it stated that it was aware of the practice of some States in employing straight baselines with respect to offshore archipelagos. ${ }^{221}$ One commentator notes that the Tribunal's reference to State practice in this context was made in a conclusion, but that the Tribunal did not follow through by analysing

\footnotetext{
219 Id. at paras. $571-76$.

220 Id. at para. 573.

221 Id. at paras. $575^{-76}$.
} 
that State practice and considering how that practice may have impacted its conclusion. ${ }^{22}$ Notably, for example, the Tribunal did not analyse the Philippines' unilateral declaration of straight baselines enclosing many of the Spratly Island features in its Presidential Decree 1596 of 1978. The Tribunal simply concluded that UNCLOS "excludes the possibility of employing straight baselines" in situations other than those expressly provided under Article 7 and Part v, "in particular with respect to offshore archipelagos". 223

The Tribunal's summary approach to this important issue is surprising because there is significant State practice of enclosing offshore archipelagos with straight baselines. ${ }^{224}$ This includes in the South China sea itself, where the Philippines effectively declared such an archipelago when making its Kalayaan Island Group declaration (Presidential Decree 1596) in 1978. Much of this State practice clearly does not relate to archipelagos that form a "fringe of islands along the coast in its immediate vicinity" for the purposes of Article 7 of unCLOS. Accordingly, those claims appear to have been made outside the straight baseline and archipelagic baseline provisions of UNCLOS. As stated above, the Tribunal confirmed that UNCLOS does not expressly preclude such baselines. ${ }^{225}$

Alongside the Philippines'1978 claim around the Kalayaan Island Group, relevant pre-UNCLOS State practice in this context includes straight baseline measures taken by Denmark in respect of the Faroes in 1963 (subsequently revised in 1976 and 2002), Norway in respect of Svalbard and its surrounding features in 1970 (amended in 2001), Ecuador in respect of the Galapagos Islands in 1971 (repeated in 2012), Spain in respect of the Canary Islands in 1977, and France in respect of the Kerguelen Islands in $1978^{226}$ (see Section II.B(ii) on claim to offshore archipelagic status based on historic rights).

State practice in respect of the drawing of straight baselines around offshore island groups has continued since the adoption of UNCLOS. It includes the United Kingdom in respect of the Turks and Caicos and the Falklands in 1989 (and Argentina for the same, i.e., Malvinas, in 1991), China in respect of the Paracels in 1996, France in respect of Guadeloupe and its surrounding features in 1999 and in respect of the Loyalty Islands in 2002, and Myanmar in respect of Co Co and Peparis Islands in 2008. ${ }^{227}$

\footnotetext{
222 J. Ashley Roach, Offshore Archipelagos Enclosed by Straight Baselines: An Excessive Claim?, 49(2) Ocean Development \& International LaW 176, 179-180 (2018).

223 Award, supra note 1, at para. 575 .

224 Roach, supra note 222, at 179. See also appendix to the article for details.

225 Award, supra note 1, at para. 575.

226 See Table 1 and Appendix in Roach, supra note 222, at 18o-81, 197-202.

227 Id.
} 
Only six of the fifteen claims to enclose offshore archipelagos have been protested, by a total of nine States. Several claims are by States that failed in their effort during the negotiation of UNCLOS to have the archipelagic regime of Part V apply to offshore archipelagos. ${ }^{228}$

It would be inaccurate to conclude, as the Tribunal appears to do, that the question of drawing straight baselines is a settled matter under UNCLOS and customary international law. In particular, as elaborated in the critique of Section V of the Award (above), UNCLOS does not preclude the possibility of offshore archipelagic claims based on historic rights. ${ }^{229}$ Accordingly, the Tribunal's apparent conclusion that any attempt to draw straight baselines around the Spratly Islands as an offshore archipelago would be contrary to international law is open to serious question.

One commentator has observed that the Tribunal "did not apply the approach used in previous international arbitration for assessing claims by continental or archipelagic states to maritime features as a single or archipelagic unit."230 The approach, as exemplified in Nicaragua v. Colombia, involves "an examination for whether there is a treaty basis as well as natural and historical bases for such claims." ${ }^{231}$ The commentator observes that the Tribunal failed to consider the San Francisco Peace Treaty and the Taipei Peace Treaty as possible bases to regard the Spratly Islands as a single unit. ${ }^{232}$ She concludes that:

The parties to the peace treaties knew and understood the Spratly Islands to mean Sinnan Gunto, an area in the South China Sea whose limits were well defined and the principal components of which were identified. This provides a sufficient basis to conclude that the Spratly Islands is "in [international] law a unit [...] [such] that the fate of the principal part may involve the rest," and this includes the named features in the Philippines/China Arbitration. ${ }^{233}$

\footnotetext{
$228 I d$.

229 See Section 2.b II.

230 Melissa H. Loja, The Spratly Islands as a single unit under international law: A commentary on the Final Award in Philippines/China Arbitration, 47(4) Journal of OcEAN Development \& International LaW 309, 311 (2016).

231 Id.

$232 I d$. at 316.

233 Id.
} 
The Tribunal did not contemplate the possibility of such claims persisting following UNCLOS. For the reasons given in the critique of Section $v$ of the Award, above, this conclusion is dubious.

\subsubsection{The Tribunal's Decision Not to Address Specifically the Status of a Number of High Tide Features under Article 121 of UNCLOS Notwithstanding Their Manifest Relevance to Its Jurisdiction}

The Tribunal observed that, by requesting in Submission nos. 5, 8 and 9 declarations about the Philippines' own EEZ, the Philippines effectively requested a general determination that all of the high tide features in the Spratly Islands are "rocks" for the purposes of Article 121(3) of UnCLOS. Accordingly, the Tribunal considered it necessary to interpret and apply Article 121(3) for "all significant high-tide features in the Spratly islands that could impact the Tribunal's jurisdiction to decide the matters raised" in those Submissions. ${ }^{234}$

However, notably, the Tribunal focused its analysis under Article 121(3) upon only six features, which it described as "the six largest features amongst the other high-tide features in the Spratly Islands":235 namely, Itu Aba (controlled by Taiwan), Thitu (controlled by the Philippines), West York Island (controlled by the Philippines), Spratly Island (controlled by Vietnam), NorthEast Cay (controlled by the Philippines) and South-West Cay (controlled by Vietnam) (the "Primary High Tide Features").

The Tribunal noted that a number of other high tide features of relevance to the extent of the Philippines' Eez: namely, Amboyna Cay, Flat Island, Loaita Island, Namyit Island, Nanshan Island, Sand Cay, Sin Cowe Island and Swallow Reef (the "Secondary High Tide Features"). However, it declined to discuss them individually, on the basis that "if the six largest features described above are all to be classified as rocks for purposes of Article 121(3) of the Convention, the same conclusion would also hold true for all other high tide features in the Spratly Islands". ${ }^{236}$ Therefore, when later concluding that the six "largest" features were "rocks" for the purposes of Article 121(3), the

\footnotetext{
234 Award, supra note 1, at paras. 393, 396.

235 Id. at para. 400.

236 Id. at para. 407 .
} 
Tribunal observed that, although it had "considered, and reache[d] the same conclusion with respect to" the Secondary Features, it was not necessary to list them individually. ${ }^{237}$

This is a surprising, and arguably unlawful, approach to a critical issue before the Tribunal (namely, whether it had jurisdiction over a number of the Submissions made by the Philippines, which in turn would depend upon whether any of the high tide features in the Spratly Islands potentially generate EEZ and continental shelf entitlement under Article 121).

First, this approach contradicts the Tribunal's own assessment of the drafting history of UNCLOS, which shows that proposals to impose "bright-line rules" around criteria such as surface area or size in the context of the rock/ island distinction were explicitly rejected. ${ }^{238}$ Accordingly, the Tribunal concluded that "size cannot be dispositive of the feature's status as a fully entitled island or rock and is not, on its own, a relevant factor". 239 But, in concluding that it was not necessary to discuss the Secondary High Tide Features individually, purely on the basis that they were smaller than the Primary High Tide Features, the Tribunal in effect imposed its own "bright-line rule".

Second, as a result, the Tribunal in effect imposed an arbitrary criterion in its interpretation of Article 121(3) that has no legal basis or justification. Indeed, even the Philippines had acknowledged that size alone could not be determinative of the status of a feature under Article $121(3),{ }^{240}$ such that it considered it necessary to make specific submissions and submit specific evidence with respect to the Secondary High Tide Features. ${ }^{241}$

Third, it is a fundamental principle of international law that any court or tribunal seized of a dispute or complaint must satisfy itself that it has jurisdiction over that dispute or complaint. ${ }^{242}$ As elaborated in Section VI.B(i) below, Article 9 of Annex VII to UNCLOS requires that an arbitral tribunal must satisfy itself that a claim is well-founded in fact and law. By refusing to address specifically the question of whether any of the Secondary High Tide Features constituted fully-fledged "islands" with their own EEz and continental shelf

\footnotetext{
237 Id. at paras. 622,625 .

238 Id. at paras. $537-38$.

239 Id. at para. 538.

240 Id. at para. 412.

241 Id. at para. 443.

242 See, e.g., Mavrommatis Palestine Concessions (Greece v. U.K.), 1924 P.C.I.J. (ser. B) No. 3 (Aug. 30) (Dissenting Opinion of Judge John Bassett Moore) at 57-58: "[t]here are certain elementary conceptions common to all systems of jurisprudence, and one of these is the principle that a court of justice is never justified in hearing and adjudging the merits of a cause of which it has not (sic) jurisdiction".
} 
entitlements, the Tribunal arguably disregarded its duty to satisfy itself of its jurisdiction as regards the Philippines' Submission nos. 5, 8 and 9. In this regard, the Tribunal simply stated that it had "also considered" and reached "the same conclusion with respect to, the other, less significant high-tide features in the Spratly Islands, which are even less capable of sustaining human habitation". ${ }^{243}$ The Tribunal's brief comment, without any accompanying reasoning or analysis related to the Secondary High Tide Features, is arguably insufficient to fulfill the Tribunal's duty to satisfy itself that it had jurisdiction over the relevant submissions of the Philippines. In default proceedings involving only one party, this duty is particularly acute.

Fourth, the Tribunal failed to give any reasons for its conclusions as regards the status of the Secondary High Tide Features under Article 121. It is a general principle of international law that any court or tribunal must give reasons for its decisions, a fortiori any decisions that are fundamental to its jurisdiction. ${ }^{244}$ By concluding that it was not necessary to discuss any of the Secondary High Tide Features individually, the Tribunal openly disregarded its obligation to give reasons with respect to issues that were a sine qua non of its jurisdiction over Submission nos. 5, 8 and 9.

\subsubsection{The Tribunal's Decision that All of the High Tide Features in the Spratly Islands Constitute "Rocks" for the Purposes of Article 121(3) of UNCLOS}

The Tribunal proceeded to review five aspects of conditions on the Primary High Tide Features, in turn, namely: (i) "the presence of potable fresh water"; (ii) "vegetation and biology"; (iii) "soil and agricultural potential"; (iv) "presence of fishermen"; and (v) "commercial operations". ${ }^{245}$ On their face, each of these factors appears legitimate for the purposes of an analysis of a feature under Article 121. However, as explained below, in applying these factors to the Primary High Tide Features, the Tribunal gave substantial (and arguably improper) weight to the additional, "qualitative" and inherently subjective, legal factors that it had identified when interpreting Article 121.

Moreover, as elaborated below, the Tribunal's assessment of the available evidence as to whether or not the Primary High Tide Features fulfilled its five factors is highly questionable.

\footnotetext{
243 Award, supra note 1, at para. 622.

244 See Case concerning Arbitral Award of 31 July 1989 (Guinea-Bissau v. Sen.), 1991 I.C.J. Rep.53 (Nov. 12) (Judgement); see also Application for Review of Judgement No. 158 of the United Nations Admin. Tribunal, 1973 I.C.J. Rep. 210-211 (July 12) (Advisory Opinion).

245 Award, supra note 1, at paras. 579-614.
} 
First, in applying its five factors the Tribunal appears to have ignored some of the evidence before it. The Tribunal commented that it had reviewed "a substantial volume of evidence concerning the conditions on the more significant of the high tide features in the Spratly Islands". ${ }^{246}$ It referred in this regard to evidence presented by the Philippines, evidence in other publicly available sources and materials obtained by the Tribunal from certain Western (British and French) archives. Notably, however, the Tribunal made no reference in this passage to the 39 evidentiary exhibits that had been provided by the Chinese (Taiwan) Society of International Law in its Amicus Curiae submission of 23 March 2016, which primarily related to human habitation and economic life on Itu Aba. ${ }^{247}$

The photographic evidence of human habitation on Itu Aba presented in the Amicus Curiae submission was only indirectly referred to in paragraph 432 of the Award, in the context of the Tribunal's summary of the Philippines' (largely rhetorical) assessment of that evidence. The Tribunal failed to refer to the photographic evidence when assessing, inter alia, the availability of potable fresh water, vegetation, agricultural potential commercial operations and the presence of fishermen. ${ }^{248}$ In effect, therefore, the Tribunal only referred to the evidence presented in the Amicus Curiae submission to the extent that it was addressed by the Philippines in its own submissions, and otherwise ignored it altogether.

Professor Wang notes that the Tribunal:

... ignored to analyze contrary evidence, like the ample documentary and other evidence submitted in the Amicus Curiae by the Chinese (Taiwan) Society of International Law. Taiwan's Amicus Curiae, citing numerous books, reports, and other forms of empirical or scientific research, aimed to prove that the Taiping Island not only had a "longstanding history of human habitation," but also "currently sustains the habitation of hundreds of people. ${ }^{249}$

\footnotetext{
246 Id. at para. 577.

247 Chinese (Taiwan) Society of International Law, Amicus Curiae submission on the Issue of the Feature of Taiping Island (Itu Aba) Pursuant to Article 121(1) and (3) of the 1982 United Nations Convention on the Law of the Sea, 23 March 2016 http://www.assidmer.net/doc/ SCSTF-Amicus-Curiae-Brief-final.pdf.

248 Award, supra note 1, at 580-614.

249 Wang, supra note 175 , at 205.
} 
Second, even on the evidence to which it did refer, it appears that Itu Aba (and possibly other features) satisfied all of the factors that it had identified as central to its Article 121(3) analysis. This is especially the case if the "qualitative" aspects of the Tribunal's interpretation of Article 121(3) are set aside. The following section sets out how Itu Aba appears to satisfy all five factors identified by the Tribunal.

\subsubsection{The Tribunal's Decision Ignores Evidence Indicating that Itu Aba Satisfied Its Own Five Factors for the Purposes of Article 121(3)}

The Chinese (Taiwan) Society of International Law submitted to the Tribunal a series of photographs evidencing historic and continuous human habitation on Itu Aba. ${ }^{250}$ Some of the photographs, however, evidence the presence of three of the five factors considered by the Tribunal in determining whether a feature can sustain human habitation on its own, including: (1) potable water (Exhibit 29); (2) vegetation and biology (Exhibit 27); (3) soil and agricultural potential (Exhibits 31, 38(1) and 38(2)). As described below, the Tribunal had further non-photographic evidence before it on all five factors. It is notable that the Tribunal does not cite to any of the photographs introduced as evidence with the Chinese (Taiwan) Society of International Law's Amicus Curiae submission, which provide clear evidence of human habitation on Itu Aba.

As regards its first factor ("the presence of potable freshwater"), despite extensive historical evidence as to the "considerable quantity" and "abundant" volumes of drinkable water on Itu Aba in particular, the Tribunal concluded that the "quality of this water will not necessarily match the standards of modern drinking water and may vary over time". ${ }^{251}$ This is despite the absence from Article 121(3) of any requirement that drinking water must be up to "modern standards" (a term which the Tribunal did not attempt to define, but which follows from its imposition of "qualitative" elements in its interpretation of that provision). In fact, as Professor Nordquist has observed, no reference is made to water at all in the text of Article 121(3), nor was any meaningful discussion held about the presence (or not) of water as a relevant during its negotiation..$^{252}$ Also, as elaborated at Annex 1 below, it is clear that many fully-entitled island features generating EEZ entitlements do not host potable freshwater, still less sufficient freshwater up to "modern standards" to support a human population.

250 Chinese (Taiwan) Society of International Law, supra note 247. The historic evidence includes photographs of buildings, temples and groundwater wells (Exhibit 27).

251 Award, supra note 1, at para. 584.

252 Nordquist, supra note 19o, at 177-9o. 
While the presence of potable freshwater is, in our view, a legitimate (though not decisive) indicator of the capacity of a feature to sustain human habitation, the Tribunal unduly inflated the importance of that factor and subjected it to unreasonable "qualitative" and "quantitative" limits that are unsupported by the text of Article 121. As a result, while the Tribunal acknowledged that the freshwater resources "have supported small numbers of people in the past", 253 it did not consider this to be conclusive as to the status of Itu Aba.

Notably, the Tribunal's assessment of the evidence of potable freshwater on Itu Aba was also lacking. For example, it did not even address the evidence before it as to the substantial volume of drinkable water available on Itu Aba, and the hundreds of people that were reliant on it during certain periods. ${ }^{254}$

In particular, the Tribunal ignored the evidence submitted by the Chinese (Taiwan) Society of International Law with its Amicus Curiae submission, including evidence from the Water Quality On-site Survey stating that the quality of the groundwater drawn from the four wells has been proved to be suitable for daily human use, and in particular, the quality of the water drawn from Well No. 5 is suitable for drinking. ${ }^{255}$

The Tribunal also failed to consider the historical evidence of potable drinking water on Itu Aba before it:

In fact, quality freshwater on Taiping Island has been recorded and attested to by a great deal of historical documentary evidence, including the China Sea Directory in 1879 and Asiatic Pilot in 1925, all evidencing that the water found in the wells on Taiping Island is suitable for drinking, and that its quality is superior to water in other locations. In 1937,

253 Award, supra note 1, at para. 584.

254 See, e.g., Exhibits 1, 2, 28 and 29 to the Chinese (Taiwan) Society of International Law, Amicus Curiae submission. See also Determination Regarding Jurisdiction of New Southern Archipelago will be Announced Today [新南群島の管轄決定きょう公告], Osaka Asahi Shimbum [大阪朝日新聞], 18 April, 1939, Exhibit 25 and Hitoshi Hiratsuka (平塚均); The advanced base for expanding fishery business to southern area: New Southern Archipelago - Report of On-site Survey [漁業南進の 前哨地. 新南群島 - 實 地調查記], Taiwan Times [台湾時報], May 1939, at 208-210, Exhibit 30 to the Chinese (Taiwan) Society of International Law, Amicus Curiae submission. According to the Amicus Curiae submission, both empirical facts and scientific studies establish that the Itu Aba has an abundant natural supply of fresh water which "is easily replenished by precipitation", which "averages $1800-2000$ mm per year". It was further presented that the four groundwater wells provided drinking and cultivating water to 237 , ooo tons per year. Chinese (Taiwan) Society of International Law, supra note 247.

255 Id. See, e.g., Exhibit 29, Ta-Wei Chang, Water Quality and Agricultural Environment Survey - Groundwater Quality and Hydrology Survey Report. 
a Japanese government official, Hitoshi Hiratsuka (平塚均), was sent to Taiping Island and recorded that out of the four wells on the Island, one well can supply about 10 tons of drinking water per day. Osaka Asahi Newspapers in 1939 also reported that drinking water was available a long time ago on Taiping Island, and fishermen used to visit the Island to obtain drinking water during sailing trips. Historical documentary evidence also shows that Taiping Island had a freshwater supply when the ROC government took over, and thereby recovered Taiping Island in 1946.256

As regards its second factor ("vegetation and biology"), the Tribunal observed various evidence that the larger features in the Spratly Islands have historically been vegetated, including through the introduction of fruit trees and vegetables to supply food on Itu Aba before and after World War II. It observed also historical evidence of the farming of chickens and pigs. ${ }^{257}$ Notably, the Tribunal had before it (but made no reference to) evidence presented of livestock being raised in modern times on Itu Aba, showing that locally raised "goats, chickens, and eggs are a source of food for people on the island".258

As regards its third factor ("soil and agricultural potential"), the Tribunal cited a 1994 scientific study indicating that "people may cultivate crops" on Itu Aba, and considered the "most instructive evidence to be the clear indication that fruit and vegetables were being grown on Itu Aba during the period of Japanese commercial activity". It observed that such cultivation "most likely reflects the capacity of the feature in its natural condition". Certainly, such evidence indicates the presence of fertile soil and agricultural potential.

However, the Tribunal went on to say that "agriculture on Itu Aba would not suffice, on its own, to support a sizeable population".259 Again, the ability of a feature to support "a sizeable population" is not relevant to the assessment of status under Article 121 of UNCLOS. Moreover, the Tribunal's reference to it contradicts its observation earlier in the Award that the "human habitation" criterion does not require capacity to support a large population, and that in remote atolls "a few individuals or family groups could well suffice". ${ }^{260}$ The Tribunal's reference to an inability is to support a "sizeable population" again

\footnotetext{
$256 \quad I d$.

257 Award, supra note 1, at paras. 586-91.

258 Chinese (Taiwan) Society of International Law, supra note 247. See, e.g., Chien-Fan Chen, Water Quality and Agricultural Environment Survey of Taiping Island-The Flora and Vegetation Survey Report, Exhibit 32.

259 Award, supra note 1, at para. 596.

26 o Id. at para. 542.
} 
appears to follow from its restrictive interpretation of Article 121(3) and the imposition of "qualitative" elements.

The Tribunal had further evidence before it showing that "[s]oil on Taiping Island is naturally formed and supports indigenous vegetation as well as agricultural crops." ${ }^{261}$ The Tribunal observed that "the historical record before the Tribunal contains less information concerning soil quality on features in the Spratly Islands". ${ }^{262}$ However, it failed to mention the following account of cultivated vegetation presented by the Chinese (Taiwan) Society of International Law Amicus Curiae submission:

Personnel stationed on the island have long utilized all types of resources on the island and cultivated various tropical vegetables and fruits, including staple foods such as corn and sweet potato as well as 10 other types such as okra, pumpkin, loofah gourd, bitter melon, and cabbage. ${ }^{263}$

As regards its fourth factor ("presence of fishermen"), the Tribunal noted evidence indicating "the consistent presence of small numbers of fishermen, mostly from Hainan, on the main features in the Spratly Islands". It cited 19th-century evidence that fishermen were able to "remain for years" among the Spratly Islands, including some that were "comfortably established" on Itu Aba, supplying themselves with water from that feature.

The Tribunal referred to 2oth-century French evidence observing that the fishing communities were growing coconut, banana and potatoes on Itu Aba, and that "there is no doubt that since time immemorial, these islands were frequented and even temporarily inhabited by the Chinese, Malay and Annamite fishermen that haunt these parts". ${ }^{264}$

The Tribunal concluded that the evidence showed that fishing communities were present in the Spratlys "for comparatively long periods of time, with an established network of trade and intermittent supply". 265

As regards its fifth and final factor ("commercial operations"), the Tribunal observed various evidence of significant commercial activities in the early 2oth century around "the working of phosphates", fisheries, guano mining and the associated presence from time to time of hundreds of workers on Itu Aba. Evidence showed that the workers obtained drinking water on the feature, and

261 Chinese (Taiwan) Society of International Law, supra note 247. See Exhibit 31, Zueng-Sang Chen, Brief Report of Soil Resources Survey of Taiping Island.

262 Award, supra note 1, at para. 594.

263 Chinese (Taiwan) Society of International Law, supra note 247.

264 Award, supra note 1, at para. 599.

265 Id. at paras. 597-6o1. 
that the place was "considerably developed as a fishery" and "a flourishing concern" before it was abandoned during World War II. ${ }^{266}$

On the basis of the evidence before it, the Tribunal concluded that "the principal high-tide features in the Spratly Islands are capable of enabling the survival of small groups of people", and that "the principal features of the Spratly Islands are not barren rocks or sand cays, devoid of fresh water, that can be dismissed as uninhabitable".267

On this basis, the Tribunal should have been able to conclude, at a minimum, that both Itu Aba on its own and (a fortiori) the Spratly Islands as a whole are capable of sustaining human habitation for the purposes of Article 121(3). It should also (separately) have been able to conclude that both Itu Aba on its own and (a fortiori) the Spratly Islands as a whole are capable of sustaining economic life of their own for the purposes of Article 121(3).

The Tribunal considered that, since a number of the features "fall close to the line in terms of their capacity to sustain human habitation", it was required to consider the historical evidence of actual human habitation and economic life before reaching any conclusions. This should not have been necessary, given the overriding "capacity" criterion in Article 121(3), which had been acknowledged by the Tribunal earlier in the Award. Nevertheless, that historical evidence indisputably showed that actual human habitation and economic life has been present on the features for significant periods in the past.

The Tribunal, however, concluded that "the criterion of human habitation is not met by the temporary inhabitation of the Spratly Islands by fishermen, even for extended periods", because they did not represent the "natural population of the Spratlys". Moreover, fishermen had not been "accompanied by their families" or comprise a "stable community". Accordingly, the shelter and facilities evidenced before it did not attain the level that the Tribunal "would expect for a population intending to reside permanently". Similarly, labourers living on the islands purposes of Japanese commercial activities during the early zoth century had not moved "to make a new life for themselves" or establish a "settled community".

As a result, the Tribunal concluded that Itu Aba, Thitu, West York, Spratly Island, South-West Cay and North-East Cay are not capable of sustaining human habitation within the meaning of Article 121(3). ${ }^{268}$

266 Id. at paras. 602-12.

267 Id. at paras. $615^{-16 .}$

268 Id. at paras. 618-22. 
This critical conclusion is subject to criticism on a number of grounds. First, as explained above, it appears to be belied by the evidence that was before the Tribunal. As Professor Nordquist has observed, the failure of the Tribunal to take note of certain developments over time on Itu Aba, about which evidence was readily available to the Tribunal, is "baffling". ${ }^{269}$ Second, as also explained above, it is based upon an overly-restrictive interpretation of Article 121, which imposes unjustified "quantitative" and inherently subjective considerations upon a definition that is inherently objective in nature. Third, the Tribunal ignored the fact that the most substantial historical population appears to have abandoned Itu Aba as a result of an "intervening force", in the form of World War II, despite the fact that it had explicitly acknowledged that such factors are relevant in the application of Article 121. Fourth, the Tribunal accorded undue weight to the presence of military or other governmental personnel on the features during modern times, and associated concerns about States establishing "artificial populations in the hope of making expansive [EEZ] claims", all of which should have been irrelevant given the substantial pre-UNCLOS evidence before it showing capacity to sustain human habitation. ${ }^{270}$

As regards "economic life", the Tribunal concluded that "all of the economic activity in the Spratly Islands that appears in the historical record has been essentially extractive in nature", for the benefit of populations elsewhere. It observed that "economic activity must be oriented around the feature itself and not be focused solely on the surrounding territorial sea or entirely dependent on external resources". ${ }^{271}$

As a result, the Tribunal concluded that Itu Aba, Thitu, West York, Spratly Island, South-West Cay and North-East Cay are not capable of sustaining economic life of their own within the meaning of Article 121(3). ${ }^{272}$

Again, this conclusion is subject to criticism on a number of grounds. First, as explained above, it appears to be belied by the evidence before the Tribunal of a history of economic life that was far from being "focused solely on the surrounding territorial sea or entirely dependent on external resources". Second, as explained above, it is again based upon the Tribunal's overly-restrictive interpretation of Article 121, which imposes unjustified "quantitative" and inherently subjective considerations upon a definition that is inherently objective in nature. Third, the Tribunal ignored the fact that the most substantial economic activity within the past 100 years appears to have ceased on Itu Aba

269 Nordquist, supra note 19o, at 197.

270 Award, supra note 1, at paras. 620-21.

271 Id. at para. 623.

272 Id. at paras. $623-25$. 
as a result of an "intervening force", in the form of World War II. Fourth, the Tribunal commented out of the blue, and without any justification on the text of Article 121, that the introduction of the EEZ by UNCLOS "was not intended to grant extensive maritime entitlements to small features whose historical contribution to human settlement is as slight as that". There is nothing in the text, or even the context, object and purpose, of Article 121 to indicate that a feature (or group of features) must have made a significant "historical contribution to human settlement" in order to be capable of generating EEZ and continental shelf rights.

In conclusion, on the evidence before it the Tribunal could easily have concluded that both Itu Aba on its own and (a fortiori) the Spratly Islands as a whole are capable of sustaining human habitation for the purposes of Article 121(3). It could also (separately) have concluded that both Itu Aba on its own and (a fortiori) the Spratly Islands as a whole are capable of sustaining economic life of their own for the purposes of Article 121(3). Either finding would have been sufficient to lead the Tribunal to conclude that one or more of the features generates EEZ and continental shelf entitlement. This, in turn, would have precluded the Tribunal from taking jurisdiction in respect of Philippines Submission nos. 5, 8, 9 and 12, and from making a number of its substantive findings on the merits (particularly dispositif nos. 7, 8, 9, 10, 14 and $16(\mathrm{a})$ and $(\mathrm{d}))$.

3.1.6 The Tribunal's Conclusion that Itu Aba and Other Features in the Spratly Islands Constitute "Rocks" for the Purposes of Article 121(3) Contradicts State Practice as Regards EEz Claims Made around Equivalent (Or Less Significant) Maritime Features

As well as being legally questionable for the reasons set out above, the Tribunal's conclusion that Itu Aba and other features constitute "rocks with no EEZ or continental shelf entitlement" for the purposes of Article 121(3) contradicts State practice.

Notably, the Tribunal ignored this State practice in its Award. Rather, and in contrast with its lengthy analysis of the travaux préparatoires, it restricted its assessment of State practice to considering whether "one can speak of an agreement reached concerning the interpretation of the provision in question". 273 The Tribunal observed that the threshold to be met in order to establish such an agreement is "quite high", and concluded that "there is no evidence for an agreement based upon State practice on the interpretation of Article 121(3)". 274

273 Id. at para. $55^{2}$ (referring to Article $31(3)(\mathrm{b})$ of the VCLT).

274 Id. at paras. $55^{2-53}$. 
Accordingly, the Tribunal did not take any account of widespread State practice showing that small uninhabited islands, including a number that are uninhabited (and without any fresh water source for the most part), have been treated as "islands" generating full maritime entitlements, including Australia's Elizabeth Island; Brazil's Martim Vaz Island; Chile's Sala y Gomez Island; Colombia's Low Cay (Bajo Nuevo Bank) and France's Matthew Island (all smaller in size than Itu Aba). ${ }^{275}$

While, in some cases, claims to EEZ and continental shelf rights around small uninhabited features are unilateral in nature, in others they have been more widely accepted by way of delimitation or otherwise. For instance, as discussed above in Section III.B(i), Venezuela's delimitation agreements with neighbouring States conferring Isla Aves maritime entitlements beyond 12 NM. For details demonstrating that Isla Aves is clearly less capable than Itu Aba of meeting the Tribunal's five tests for fully-entitled island status under Article 121, see Table 1 (Small features mutually recognised as being fully entitled under Article 121(2)) in Annex 1 to this Critique. Table 1 also contains further examples of features that have been mutually accepted as being fully-entitled islands in delimitation, but which fail more obviously than Itu Aba to meet the Tribunal's five tests. Table 2 identifies a number of further examples of features much more insignificant than Itu Aba that are nevertheless claimed unilaterally by States as being fully-entitled islands under UNCLOS.

As one commentator has observed, the Tribunal's reasoning and conclusion in relation to Itu Aba alone, "if applied universally, would imply that a large number of such high-tide elevations in the oceans should be stripped of their present EEZ and continental shelf entitlements."276

In a recent study, ${ }^{277}$ Myron Nordquist and William Phalen identified a number of islands, recognised as such through "decades of State Practice", ${ }^{278}$ which would likely be considered Article 121(3) "rocks" if the Tribunal's reasoning were to be applied:

(i) Johnston Island and Atoll (area 2.63 $\mathrm{km} 2$ ): in its natural condition does not contain fresh water, food and living space and materials for human shelter nearly to the extent as does Itu Abu. Further, the only major industry outside of military activities that has occupied the islands has been guano mining, which the Tribunal classified as a "purely extractive

275 See Talmon, supra note 33 , at $83^{-86 .}$

276 Hafner, supra note 139, at 10.

277 Myron H. Nordquist \& William G. Phalen, Interpretation of UNCLOS Article 121 and Itu Aba (Taiping) in the South China Sea Arbitration Award, in International Marine ECONOMY (2017).

278 Id. at 69 . 
economic activity, thus disqualifying the Atoll from any ability to sustain an economic life of its own. ${ }^{279}$ Nonetheless, the United States has claimed the EEZ surrounding the atoll, without objection, since March 1983.

(ii) Clipperton Island (area 6km2): serves as another glaring example of a maritime feature that has long been recognized by the international community as an Article 121 island entitled to a 200nm EEZ and continental shelf. Yet, the island would fail the test in the Award as applied to Itu Aba. ${ }^{280}$ Attempts at settlement on the island in the early 2oth century failed without continuous resupply ships, so the history of the island suggests that the feature cannot independently sustain human habitation or an economic life of its own according to the test laid down by the Tribunal.

(iii) Trindade Island (area $10.1 \mathrm{~km} 2$ ): the island today is almost entirely barren" and the "current physical characteristics of Trindade would make survival on the feature's resources without the aid of modern technology extremely difficult if not impossible. ${ }^{281}$ In 2004, Brazil declared an EEZ, which included a $200 \mathrm{~nm}$ zone surrounding Trindade. There has been no objection from the international community.

If the Tribunal's analysis were to be adopted as a universal standard, it would potentially result in the reclassification of certain islands which unequivocally have full maritime entitlements.

For example, in its Award, the Tribunal stated that: (i) a "feature that is only capable of sustaining habitation through the continued delivery of supplies from outside does not meet the requirements of Article 121(3);282 (ii) the economic life "must be oriented around the feature itself and not focused solely on the waters or seabed of the surrounding territorial sea";283 and (iii) "size cannot be dispositive of a feature's status as a fully entitled island or rock and is not, on its own, a relevant factor."284

Taking each of these in turn in relation to Kiritimati (otherwise known as Christmas Island): (i) the island is susceptible to severe drought and "the contemporary population of nearly 8,ooo people is dependent upon shipments from Kiribati's capital for potable water and food"; ${ }^{285}$ (ii) whilst the island's reef system is productive and supports the population's nutrition, this does not

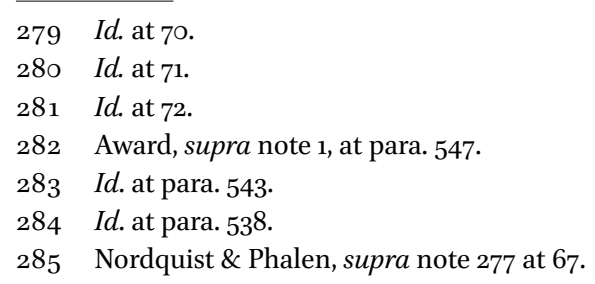


satisfy the Tribunal's preference that resources of the feature itself should be considered when determining habitability; and (iii) according to the Tribunal, the size of the island cannot be determinative in its classification, in part because there is no substantive difference between an "island" and a "rock". Therefore, Kiritimati would apparently fail to meet the characteristics imposed by the Tribunal in order to be classified as an "island" under Article 121. To the contrary, in fact Kiritimati is internationally recognised as an island having full maritime entitlements. ${ }^{286}$

Nordquist and Phalen "believe, for reasons explained in [their] Study, that it is unrealistic to expect widespread repudiation of decades of unprotested State Practice relevant to the regime of islands throughout the world's oceans." ${ }^{287}$ In our view, supported by the examples set out above, the Tribunal's decision on Itu Aba contradicts State practice with regards to EEz claims made around equally small or much smaller features, or features that are less likely than Itu Aba to be able to sustain human habitation or an economic life of their own. The Tribunal therefore erred in dismissing the relevance of State practice in this instance. The universal application of its reasoning could result in reclassifications that would contradict State practice, depriving many States of long-standing maritime rights.

\section{The Tribunal's Findings with Respect to Chinese Activities in the South China Sea (Philippines Submissions Nos. 8 to 13; Award Chapter VII)}

This section analyses the Tribunal's conclusions and findings with respect to the Philippines' submissions relating to certain Chinese activities in the South China Sea. After an introductory section on issues of jurisdiction, it considers the following Tribunal findings:

Section 4.1: that China breached its obligations under Articles 77 and ${ }_{5} 6$ of UNCLOS with respect to the Philippines' sovereign rights over the nonliving resources of its continental shelf in the area of Reed Bank and the living resources in its EEZ (Submission no. 8; Tribunal merits dispositif nos. 8 and 9);

286 Id. at 67-68. "While the island of Kiritimati has nearly all of the limitations for human habitation identified by the Tribunal in its analysis of Itu Aba/Taiping (i.e. minimal freshwater, calcareous soil, zero agricultural potential), before this Award there was consensus in the international community that it was entitled to a $200-\mathrm{nm}$ EEZ as demonstrated by uncontested State Practice."

Id. at $77-78$. 
Section 4.2: that China failed to exhibit "due regard" for the Philippines' sovereign rights over fisheries in its EEZ, and accordingly China breached its obligations under Article 58(3) of UNCLOS (Submission no. 9; Tribunal merits dispositif no. 10);

Section 4.3: that, from May 2012 onwards, China unlawfully prevented Filipino fishermen from engaging in traditional fishing at Scarborough Shoal (Submission no. 10; Tribunal merits dispositif no. 11);

Section 4.4: that, with respect to the protection and preservation of the marine environment in the South China Sea, China breached its obligations under Articles 123, 192, 194(1), 194(5), 197, and 206 of UNCLOs (Submissions nos. 11 and $12(\mathrm{~b})$; Tribunal merits dispositif nos. 12 and 13);

Section 4.5: that, through its construction of artificial islands, installations and structures at Mischief Reef, China breached Articles 60 and 80 of UNCLOS (Philippines Submission no. 12 (a) and (c); Tribunal merits dispositif no. 14); and

Section 4.6: that China's operation of its law enforcement vessels on 28 April 2012 and 26 May 2012 violated Rules 2, 6, 7, 8, 15, and 16 of the Convention on the International Regulations for Preventing Collisions at Sea ("COLREgs") and, as a consequence, breached its obligations under Article 94 of UNCLOS (Philippines Submission no. 13; Tribunal merits dispositif no. 15).

\subsection{Issues of Jurisdiction}

A few important points on jurisdiction are worth noting from the outset.

4.1.1 The Effect of the Tribunal's Previous Determinations on "Historic Rights" and the Status of Features in the South China Sea

As discussed and critiqued above, the Tribunal had previously determined that:

there is no legal basis for any Chinese historic rights, or other sovereign rights and jurisdiction beyond those provided for in the Convention, in the waters of the South China Sea encompassed by the 'nine-dash line';288

288 Award, supra note 1, at para. 692. We note that this finding is not set out in the dispositive on Submissions nos. 8, 9 and 12, however, it is a necessary assumption underlying the Tribunal's findings on its jurisdiction. 
none of the high-tide feature in the Spratly Islands is a fully entitled island for the purposes of Article 121 of [UNCLOS];;289 and

Mischief Reef and Second Thomas Shoal are low-tide elevations [which], as such, generate no entitlement to maritime zones of their own. ${ }^{290}$

The Tribunal relied heavily on these three premises in reaching its substantive conclusions in Chapter VII - in particular, with respect to its findings on Submission nos. $8,{ }^{291} 9^{292}$ and $12 .{ }^{293}$ For reasons elaborated elsewhere in this critique, each of these premises is subject to substantial doubt, whether from a legal or a factual perspective.

Had the Tribunal found differently with respect to China's historic rights and/or the status of features in the South China Sea (including the status of Mischief Reef), it would also have faced the possibility of overlapping entitlements in the disputed areas. Accordingly, it would have been required to decline jurisdiction over the Philippines' Submissions nos. 8 and $9^{294}$ and it could not have found that China had breached Articles 77 and 56 of UNCLOS, 295 nor Article $58(3) .296$

Similarly, had the Tribunal found that some of the features in the Spratly Islands (in particular Itu Aba) were fully-entitled islands for the purpose of Article 121(1) of UNCLOS, or that Mischief Reef was a high-tide feature, it would have faced the possibility of overlapping entitlements and would thus have

289 Id. at para. 692; see also Tribunal jurisdiction dispositif nos. 3(a) and 5(a) which state that: "no maritime feature claimed by China within 200 nautical miles of Mischief Reef or Second Thomas Shoal constitutes a fully entitled island for the purposes of Article 121 of the Convention and therefore [...] no maritime feature claimed by China within 200 nautical miles of Mischief Reef or Second Thomas Shoal has the capacity to generate an entitlement to an exclusive economic zone or continental shelf".

290 Award, supra note 1, at para. 693; Tribunal jurisdiction dispositif nos. 3(b) and 5(b).

291 Award, supra note 1, at paras. 692-93.

292 Id. at para. 734.

293 Id. at para. 1025.

294 Id. at para. 691. Contrary to its finding in the jurisdiction dispositif no. 3. As acknowledged by the Tribunal with respect to Submission no. 8: "[h]ad the Tribunal found that another maritime feature claimed by China within 200 nautical miles of the relevant areas were a fully entitled island for purposes of Article 121 of [UNCLOS] and capable of generating an entitlement to an exclusive economic zone and continental shelf, it would necessarily have had to decline jurisdiction over the dispute".

295 Id. at merits dispositif nos. 8 and 9.

296 Id. at merits dispositif no. 10. 
been required to decline jurisdiction over Submissions nos. 12(a) and (c). ${ }^{297}$ Accordingly, it could not have found that, through its construction of artificial islands, installations, and structures at Mischief Reef, China had breached Articles 60 and 80 of UNCLOS. ${ }^{298}$

4.1 .2

The Tribunal's Finding that China's Activities were of a Civilian

Nature and that It Therefore had Jurisdiction over Submission

Nos. 11 and 12(B) (Tribunal Jurisdiction Dispositif No. 4)

For the purposes of the Philippines' Submission nos. 11 and 12(b), the Tribunal was required to determine whether its jurisdiction was constrained by the "military activities" exception set out at Article 298(1)(b) of UNCLOs. ${ }^{299}$

Pursuant to Article 9 of Annex VII to UnCLOs, "[b]efore making its award, the arbitral tribunal must satisfy itself not only that it had jurisdiction over the dispute but also that the claim is well founded in fact and law".300

The ICJ, which is subject to a similar provision (Article 53 of the ICJ Statute), held in the Nuclear Tests cases that "[i]n view of the non-appearance of the Respondent, it was especially incumbent upon the Court to satisfy itself that it is in possession of all the available facts". 301

Judge Wolfrum, in an earlier ITLOS case, considered that the phrase "well founded in fact and law" was "not a standard of proof in the sense of 'preponderance of evidence"' and that it was "rather comparable to the standard of proof in the sense of 'proof beyond reasonable doubt' as applied in

297 Contrary to the Tribunal's finding in the jurisdiction dispositif, no. 5 .

298 Award, supra note 1, at merits dispositif no. 14.

299 Id. at paras. 934-38.

300 The Tribunal explicitly confirmed that it had the responsibility to establish the limits of its jurisdiction proactively (see, in particular, Procedural Order No. 4, 21 April 2015, at para. 1.4). The Tribunal also referred to the "special responsibility" that China's nonparticipation imposed on the Tribunal. Award, supra note 1, at para. 129.

301 See, e.g., Nuclear Tests (Austl. v. Fr.), 1974 I.C.J. Rep. 253 (Dec. 20) (Judgement) at para. 31. The Court also considered that "It is to be regretted that the French Government has failed to appear in order to put forward its arguments on the issues arising in the present phase of the proceedings [jurisdiction], and the Court has thus not had the assistance it might have derived from such arguments or from any evidence adduced in support of them. The Court nevertheless has to proceed and reach a conclusion, and in doing so must have regard not only to the evidence brought before it and the arguments addressed to it by the Applicant, but also to any documentary or other evidence which may be relevant. It must on this basis satisfy itself, first that there exists no bar to the exercise of its judicial function, and secondly, if no such bar exists, that the Application is well founded in fact and in law" (at para. 15) (emphasis added). 
many national legal systems". ${ }^{302}$ Certain commentators have explained that "[t]he methods applied by the $[\mathrm{ICJ}]$ in order to verify that the submissions of the appearing party are well founded in fact" include, inter alia, "expert inquiries" and "information in the public domain". ${ }^{303}$ This is notwithstanding that the Court "cannot by its own enquiries entirely make up for the absence of one of the Parties". 304

In this case, the Tribunal upheld the Philippines' argument that "China has repeatedly characterised its island-building as being for civilian purposes". 305 Relying on "China's repeated statements that its installations and islandbuilding activities are intended to fulfil civilian purposes" the Tribunal held that it "will not deem activities to be military in nature when China itself has consistently and officially resisted such classifications and affirmed the opposite at the highest levels". ${ }^{306}$ The Tribunal thus relied exclusively on statements of China's officials supporting the Philippines' position in determining that the "military activities" exception did not apply, and that it therefore had jurisdiction to consider the Philippines' complaints about China's island-building and land reclamation activities. ${ }^{307}$

The Tribunal could (and, arguably, should) have looked for further evidence in relation to this important jurisdictional issue. We note, in particular, that the Tribunal asked the Philippines to comment on the statements of China's Foreign Ministry spokesperson, Hua Chunying, who stated on 9 April 2015, inter alia, that "[a]fter the constructions, the islands and reefs will be able to provide all-round and comprehensive services to meet various civilian demands besides satisfying the need of necessary military defense". ${ }^{308}$

302 The M/V Saiga (No. 2) Case (Saint Vincent v. Guinea), 1999 I.T.L.O.S. No. 2 (Separate opinion of Vice-President Wolfrum) at para. 12.

303 A. Zimmermann, K. Oellers-Frahm, C. Tomuschat \& C. J. Tams, The Statute of the International Court of Justice: A Commentary 1347 (2013) at para. 59.

304 Military and Paramilitary Activities, supra note 71, at para. 30.

305 Award, supra note 1, at para. 893.

306 Id. at paras. 935, 938. The Tribunal relied, in particular, on statements from a Chinese Foreign Ministry Spokesperson, the Head of China's delegation to the Meeting of States Parties to the UN Convention of the Law of the Sea and China's President, Xi Jiping (Award, at paras. 936-937). See also Award, supra note 1, at paras. 1027-1028, regarding Philippines Submissions nos. 12(a) and 12 (c).

307 Award, supra note 1, at para. 938.

308 Philippines' responses to the Tribunal's 5 February 2016 Request for Comments, 11 March 2016, at para. 5 . 
Despite this statement, the Philippines argued that the "military exception" at Article 298(1)(b) of UNCLOS was inapplicable, ${ }^{309}$ and that "mixed-use projects" and situations "in which a military unit is used to protect other activities" were not covered by this exception. ${ }^{310}$ The Tribunal did not decide on the dualuse of projects argument, however, and simply held that it accepted "China's repeatedly affirmed position that civilian use compromises the primary (if not the only) motivation underlying the extensive construction activities on the seven reefs in the Spratly Islands".311

The Tribunal's reasoning does not appear to account for any "reasonable doubt" on the civilian nature of the constructions, which plainly existed based on the above-mentioned statement. The Tribunal could have asked the Philippines to produce further evidence on this issue or could have looked for information in the public domain (which in fact demonstrated military elements of the construction and land reclamation activities). ${ }^{312}$ In any event, had the Tribunal decided to rely on contemporaneous information in the public domain it should have requested that the Parties comment on it. Arguably, this violated its duty under Article 9 of Annex VII to UNCLOS to satisfy itself that it had jurisdiction over the dispute.

\subsection{The Tribunal's Finding that China Breached Its Obligations under Articles 77 and 56 of UNCLOs (Philippines Submission No. 8; Tribunal Merits Dispositif Nos 8 and 9) \\ 4.2.1 The Tribunal's Finding that China's Actions in Connection with the Survey Operations of $\mathrm{M} / \mathrm{V}$ Veritas Voyager Amounted to a Breach of Article 77 of UNCLOS}

The Philippines presented three complaints that China had violated its sovereign rights to the continental shelf. These related to: first, Chinese diplomatic objections to the Philippines government regarding certain offshore oil and gas activities; second, a Chinese statement to a Philippines concessionaire (Nido Petroleum Ltd) to the effect that the concession area was claimed by China; and third, specific actions by Chinese maritime surveillance vessels with regard to survey operations undertaken by the M/V Veritas Voyager around Reed Bank.

\footnotetext{
309 Id. at para. 6.

310 Award, supra note 1, at para. 893; Merits Hearing Tr. (Day 4) at 104.

311 Award, supra note 1, at para. 938.

312 See, e.g., China lands military plane on disputed South China Sea reef, 18 April 2016, ввС News, https://www.bbc.co.uk/news/world-asia-china-36o69615; Philippines warning over China's South China Sea reclamation, 20 April 2015, ввC News, https://www.bbc.co.uk/ news/world-asia-32377198.
} 
The Tribunal found no violation in respect of the first two complaints. In relation to the third incident, the Tribunal declared that China had breached its obligations under Article 77 of UNCLOS:

China has, through the operation of its marine surveillance vessels in relation to M/VVeritas Voyager on 1 and 2 March 2011, breached its obligations under Article 77 of the Convention with respect to the Philippines' sovereign rights over the non-living resources of its continental shelf in the area of Reed Bank [Liyue Tan]. ${ }^{313}$

In finding that China's actions in connection with the survey operations of M/V Veritas Voyager amounted to a breach of Article 77 of UNCLOS, the Tribunal relied on the Philippines Navy's account of events, which it accepted as "accurate". ${ }^{14}$ Based on that evidence, the Tribunal considered that "China acted directly to induce $\mathrm{M} / \mathrm{V}$ Veritas Voyager to cease operations and to depart from an area that constitutes part of the continental shelf of the Philippines". 315

The Tribunal further stated that "China was unequivocally aware that there existed a difference of views regarding the Parties' respective entitlements in the South China Sea and, in particular, in the area of Reed Bank".316 It considered that, instead of seeking to resolve the dispute through negotiation or other modes of dispute resolution identified in Part XV of [UNCLOS] and the UN Charter, "China sought to carry out its own understanding of its rights through the actions of its marine surveillance vessels". ${ }^{317}$

The fact that China tried to dissuade M/V Veritas Voyager from undertaking further work in the disputed area does not seem to be disputed. If accurately reported by the Philippines, China confirmed that "[o]n 2 March, Chinese maritime surveillance vessels were in the area" and that "[t]he vessels dissuaded the Forum vessel from further work".318 China explained that "[t]his was an action that China had to take to safeguard its sovereignty and sovereign rights as a result of the unilateral action from the Philippine side".319

\footnotetext{
313 Award, supra note 1, at para. 716.

314 Id. at para. 707.

315 Id. at para. 708.

316 Id.

317 Id.

318 Id. at para. 658 (referring to Memorandum from the Acting Assistant Secretary for Asian and Pacific Affairs, Department of Foreign Affairs, Republic of the Philippines, to the Secretary of Foreign Affairs (10 March 2011) (Annex 70)).

319 Id.
} 
The Tribunal's finding that China violated Article 77 of UNCLOS with respect to the $\mathrm{M} / \mathrm{V}$ Veritas Voyager incident is limited to that specific event and must be understood in that context.

The Tribunal dismissed the Philippines' remaining two complaints. It accepted that China had asserted claims to rights in waters within $200 \mathrm{NM}$ of the Philippines' baselines "in good faith", and did not dispute that China's understanding of its rights in the South China Sea had been "genuinely held". 320 Accordingly, it dismissed the Philippines' complaints about China's diplomatic objections generally regarding offshore oil and gas activities, ${ }^{321}$ and about the Chinese Embassy's with Nido Petroleum. ${ }^{322}$

The implications of the Tribunal's finding of violation by China of Article 77 of UNCLOS are therefore highly limited in both time and scope. They relate to one solitary incident that occurred over two days in March 2011.

More generally and, as explained above (Section IV.A(i)), the Tribunal's conclusion is premised on its finding that the area in dispute "can only constitute the exclusive economic zone of the Philippines" 323 and "constitutes part of the continental shelf of the Philippines". ${ }^{324}$ Had the Tribunal not reached this (highly questionable) conclusion, it could not have found that China had breached Article 77 of UNCLOS.

4.2.2 The Tribunal's Finding that the 2012 Moratorium on Fishing in the South China Sea Amounted to a Breach of Article 56 of UnCLOS The Tribunal also found a breach of Article 56 of UNCLOS, again based on a single Chinese measure:

China has, by promulgating its 2012 moratorium on fishing in the South China Sea, without exception for areas of the South China Sea falling within the exclusive economic zone of the Philippines and without limiting the moratorium to Chinese flagged vessels, breached its obligations under Article 56 of the Convention with respect to the Philippines' sovereign rights over the living resources of its exclusive economic zone. ${ }^{325}$

\footnotetext{
320 Id. at para. 704 .

321 Id. at para. 705 .

322 Id. at para. 706 .

323 Id. at para. 695 .

324 Id. at para. 708 .

325 Id. at para. 716 .
} 
The Tribunal found that China's 2012 moratorium on fishing in the South China Sea (the "2012 fishing moratorium") "constituted an assertion by China of jurisdiction in areas in which jurisdiction over fisheries is reserved to the Philippines through the operation of the provisions of [UNCLOS] concerning the [EEZ]". ${ }^{326}$ It concluded that "such an assertion of jurisdiction amounts to a breach of Article 56 of [UNCLOS], which accords sovereign rights to the Philippines with respect to the living resources of its [EEZ]".327

Two points can be noted in the Tribunal's reasoning. First, the Tribunal failed to adduce any evidence that the 2012 fishing moratorium was enforced against any Philippines vessels in areas allegedly falling within the Philippines' EEZ. The Tribunal asked the Philippines whether it could provide evidence that this had happened. ${ }^{328}$ When the Philippines failed to do so, the Tribunal appears simply to have changed the question, holding instead that "the relevant question is whether China's 2012 promulgation of the fishing moratorium itself, irrespective of whether the moratorium was directly enforced, infringes on the rights of the Philippines and constitutes a breach of the Convention". 329

Second, the Tribunal's finding on the "deterring effect" of the 2012 fishing moratorium was similarly not corroborated by clear evidence. Rather, the Tribunal appears to have based its finding on a series of inferences; namely, that "the moratorium established a realistic prospect that Filipino fishermen, seeking to exploit resources of the Philippines' exclusive economic zone, could be exposed to the punitive measures spelled out in the moratorium" and that "such developments may have a deterring effect on Filipino fishermen and their activities". ${ }^{330}$

Again, the Tribunal dismissed with respect to this submission most of the acts invoked by the Philippines in support of its allegations. ${ }^{331}$ The Tribunal's finding of a breach should once more be understood in that narrow context.

\footnotetext{
326 Id. at para. 712 .

327 Id.

328 Id. at para. 710.

329 Id. at para. 711.

330 Id. at para. 712.

331 In particular, the Tribunal did not consider that the Hainan Regulation "infringe[d] on the rights of the Philippines or amount[ed] to a breach of the provisions of the Convention concerning the [EEZ]" (Id. at para. 713). It also held that, in the absence of evidence showing that "Chinese Government vessels acted to prevent Filipino fishermen from fishing at either Second Thomas Shoal or Mischief Reef", it was not "prepared to find a violation of the Convention on this basis" (Id. at paras. 714-15).
} 


\subsection{The Tribunal's Finding that China Breached Its Obligations under Article 58(3) of UNCLOs (Philippines Submission No. 9; Tribunal Merits Dispositif No. 10)}

The Tribunal declared that China had breached its obligations under Article 58(3) of UNCLOS on the following basis:

that in May 2013, fishermen from Chinese flagged vessels engaged in fishing within the Philippines' exclusive economic zone at Mischief Reef and Second Thomas Shoal;

that China, through the operation of its marine surveillance vessels, was aware of, tolerated, and failed to exercise due diligence to prevent such fishing by Chinese flagged vessels; and that therefore China has failed to exhibit due regard for the Philippines' sovereign rights with respect to fisheries in its exclusive economic zone. ${ }^{332}$

The Tribunal considered that the "obligation to have due regard to the rights of the Philippines is unequivocally breached when vessels under Chinese Government control act to escort and protect Chinese fishing vessels engaged in fishing unlawfully in the Philippines' [E EZ]". ${ }^{333}$ As a matter of fact, it determined that "Chinese fishing vessels, accompanied by the ships of [China Marine Surveillance], were engaged in fishing at both Mischief Reef and Second Thomas Shoal in May 2013". 334

Once more, the Tribunal made its finding on the basis of limited evidence, itself acknowledging that " $t \mathrm{t}]$ he record of Chinese fishing at these features is restricted to reports from the Armed Forces of the Philippines and confined to a single period in May 2013". ${ }^{335}$ Despite that limited evidence, the Tribunal held that it was prepared to accept the Philippines' account of events as "accurate".336

332 Award, supra note 1, at merits dispositif no. 10.

333 Id. at para. 756 .

334 Id. at paras. 746,753 .

335 Id. at para. 745. The Tribunal referred to the Armed Forces of the Philippines. Nearoccupation of Chinese Vessels at Second Thomas Shoal (Ayungin) in the Early Weeks of May 2012 (May 2013) (Annex 94). The Tribunal also considered that "China's de facto control over the waters surrounding both features effectively limit the information available to the Philippines and to this Tribunal" (Id.).

$336 I d$. at para. 746. It is also noteworthy that the incidents described in the Armed Forces report, and which constituted the basis for the Tribunal's finding of a breach of Article 58(3) of UNCLOS, happened after the "dispute" had crystallised and after the Philippines had initiated arbitration against China. 
The Tribunal provided two reasons for accepting the Philippines' Armed Forces report's account of events. It first found that China's assertion of jurisdiction over the activities of Chinese fishermen in the South China Sea - evidenced through the issuance of a 'Nansha Certification of Fishing Permit' - supported the Philippines' contention that Chinese vessels had been fishing at Mischief Reef and Second Thomas Shoal. ${ }^{337}$ The two documents on which the Tribunal relied do not, however, provide direct evidence that such permit was actually issued at the relevant time (i.e. in May 2013), nor for the relevant areas (i.e. Mischief Reef and Second Thomas Shoal). ${ }^{338}$ Furthermore, as explained below in Section vi.B(iii), the fact that China asserts the right to fish does not mean that Chinese vessels have conducted such fishing activities; still less does it show that China failed to have "due regard" to any rights to which the Philippines may be entitled for the purposes of Article 58(3).

The Tribunal then considered that "the pattern of Chinese fishing activity at Mischief Reef and Second Thomas Shoal [was] consistent with that exhibited at other reef formations for which the Tribunal has information". ${ }^{339}$ The Tribunal here appears to have determined pertinent facts simply by analogy and inference:

First, the Tribunal referred to the presence of Chinese fishing vessels at Subi Reef in May 2013 and at Scarborough Shoal in April and May 2012. ${ }^{340}$ It considered that "the accounts of officially organised fishing fleets from Hainan at Subi Reef and the close coordination exhibited between fishing vessels and government ships at Scarborough Shoal support an inference that China's fishing vessels are not simply escorted and protected, but organised and coordinated by the Government". ${ }^{341}$

Second, it noted that "Subi Reef and Scarborough Shoal [were] not, as a legal matter, comparable to Mischief Reef and Second Thomas Shoal". ${ }^{342}$ It considered, however, that "the similarities in Chinese fishing activities at all of these features [were] a significant indication of what has taken place at Mischief Reef and Second Thomas Shoal". ${ }^{43}$

337 Id. at para. 747.

338 Note Verbale from the Department of Foreign Affairs, Republic of the Philippines, to the Embassy of the People's Republic of China in Manila, No. 15-2341 (16 June 2015) (Annex 69o).

339 Id. at para. 748.

340 Id. at paras. $748-49$.

341 Id. at para. 755 .

342 Id. at para. $75^{\circ}$.

343 Id. at para. 751 . 
The evidence relied upon by the Tribunal in finding that China had breached its obligations under Article 58(3) of UNCLOS was thus very limited and, in many respects, circumstantial. Arguably, as set out in Section vi.B.(iii) below, the Philippines failed to meet its burden of proof with respect to this claim, and it should have been discussed. The implications of the Tribunal's conclusion on this Submission are in any event highly limited due to the fact that it arose out of one solitary incident in May 2013.

\section{$4 \cdot 4$}

\section{The Tribunal's Finding that, from May 2012 Onwards, China Unlawfully Prevented Filipino Fishermen from Engaging in Traditional Fishing at Scarborough Shoal (Philippines Submission} No. 10; Tribunal Merits Dispositif No. 11)

The Tribunal found that "Scarborough Shoal has been a traditional fishing ground for fishermen of many nationalities" and declared that "China has, through the operation of its official vessels at Scarborough Shoal from May 2012 onwards, unlawfully prevented fishermen from the Philippines from engaging in traditional fishing at Scarborough Shoal". ${ }^{344}$

A number of elements of this holding are open to question. Particularly questionable are the Tribunal's conclusions that: (i) traditional fishing rights can exist in territorial sea areas but not EEZ areas; (ii) even then, traditional fishing rights can vest only in the individual in respect of traditional artisanal fishing, as opposed to vesting in the coastal State; and (iii) the evidence before it demonstrated the existence of Filipino traditional artisanal fishing rights around Scarborough Shoal. Each of these points is addressed in turn below.

4.4.1

The Tribunal's Position on the Survival of Traditional Fishing

Rights in the Different Maritime Zones after the Adoption of UNCLOS

The Tribunal analysed whether traditional fishing rights had survived the adoption of UNCLOS in the different maritime zones.

With regard to archipelagic waters, the Tribunal observed that traditional fishing rights were expressly protected by Article 51(1) of UNCLOS. ${ }^{345}$

344 Id. at merits dispositif no. 11; Id. at para. 814. See also, Award, supra note 1, at para. 810: "since May 2012, Chinese Government vessels have acted to prevent entirely fishing by Filipino fishermen at Scarborough Shoal for significant, but not continuous, periods of time. The Philippines has provided evidence of Chinese vessels physically blockading the entrance to Scarborough Shoal, and Filipino fishermen have testified to being driven away by Chinese vessels employing water cannon. During these periods, Chinese fishing vessels have continued to fish at Scarborough Shoal".

Id. at para. $804(\mathrm{a})$. 
The Tribunal also held that traditional fishing rights could be recognised in the territorial sea. It considered that UNCLOS "continued the existing legal regime largely without change". ${ }^{346}$ The Tribunal saw "nothing that would suggest that the adoption of [UNCLOS] was intended to alter acquired rights in the territorial sea and conclude[d] that within that zone ... established traditional fishing rights remain protected by international law".347 The Tribunal sought support for this finding by "not[ing] that the vast majority of traditional fishing takes place in close proximity to the coast". ${ }^{348}$ This statement is unsubstantiated and we see no basis for the finding. It is also at odds with the Tribunal's finding (noted above) that traditional fishing rights continue to exist in archipelagic waters because UNCLOS expressly protects them.

In contrast to its findings in respect of archipelagic waters and the territorial sea, the Tribunal considered that traditional fishing rights in the EEZ were "extinguished". 349

The Tribunal first noted that it disagreed with the Eritrea v. Yemen tribunal, which held that "the traditional fishing regime in the Red Sea extended throughout the maritime zones of those States". ${ }^{350}$ It considered that "that tribunal was able to reach the conclusions it did only because it was permitted to apply factors other than the Convention itself under the applicable law provisions of the parties' arbitration agreement". ${ }^{351}$ As explained above in connection with Chapter $\mathrm{V}$ of the Award, the mere fact that the Eritrea/Yemen tribunal benefited from a broader "applicable law" provision does not justify a finding that its substantive conclusion as regards the continuing nature of traditional fishing rights within EEZ areas was wrong as a matter of international law.

The Tribunal then relied on Article 62(3) of UNCLOS, which requires coastal states to exercise their sovereign rights in the EEZ in such a way that minimises the economic dislocation of foreign fishermen. It considered that "the inclusion of this provision - which would be entirely unnecessary if traditional fishing rights were preserved in the [EEZ] - confirms that the drafters of the Convention did not intend to preserve such rights". ${ }^{352}$ It concluded that, following UNCLOS, traditional fishing rights can continue within the EEZ only at the discretion of the relevant coastal State.

\footnotetext{
$346 I d$. at para. $804(\mathrm{c})$.

347 Id.

348 Id.

349 Id. at para. $804(\mathrm{~b})$.

$35^{\circ} I d$. at para. 803 .

$35^{1}$ Id.

$35^{2} I d$. at para. $804(\mathrm{~b})$.
} 
This seems mistaken. As explained earlier (see Section II), and contrary to the Tribunal's conclusion, historic rights (including historic fishing rights) may continue as a matter of general public international law, within both EEZ and territorial sea areas, notwithstanding the Convention. ${ }^{353}$ It is also non-sensical for the Tribunal to have concluded that the protection of traditional fishing rights at international law is a matter within the discretion of the coastal State following UNCLOS.

Commentators have also highlighted the "serious anomaly" that the Tribunal's interpretation of traditional fishing rights in the different maritime areas would create: namely, that foreign fishermen may have greater rights to fish in the coastal State's territorial sea than they would have in its EEz. ${ }^{354}$

\subsubsection{The Tribunal's Interpretation of Traditional Fishing Rights as}

Private Rights (As Opposed to State Rights)

The Tribunal held that traditional fishing rights were private rights rather than States' rights. It first noted that the "[ $t]$ he legal basis for protecting artisanal fishing stems from the notion of vested rights". ${ }^{355}$ It then considered that "artisanal fishing rights attach to the individuals and communities that have traditionally fished in an area" and were "not the historic rights of States, as in the case of historic titles, but private rights". ${ }^{356}$ The Tribunal relied on Eritrea $v$. Yemen, where the tribunal "declined to endorse 'the western legal fiction whereby all legal rights, even those in reality held by individuals, were deemed to be those of the State". 357

It is questionable as to whether the Eritrea $v$. Yemen tribunal's reasoning should have been so readily applied to the South China Sea. In particular, the Eritrea v. Yemen tribunal explained that it had based "this aspect of its Award on Sovereignty on the respect for regional legal traditions". ${ }^{358}$ These included, for instance, " $t \mathrm{t}]$ he basic Islamic concept by virtue of which all humans are 'stewards of God' on earth, with an inherent right to sustain their nutritional needs through fishing from coast to coast with free access to fish on either side and to trade the surplus". 359 This "regional legal tradition" is of course absent

\footnotetext{
353 See Section 2.b.

354 See, e.g., Chris Whomersley, The Award on the Merits in the Case Brought by the Philippines against China Relating to the South China Sea: A Critique, 16 Chinese Journal of INTERNATIONAL LAW 387, 413 (2017).

355 Award, supra note 1, at para. 798.

356 Id.

357 Id.

358 Sovereignty and Maritime Delimitation in the Red Sea, supra note 16, at para. 92.

359 Id.
} 
from the South China Sea context with respect to the bilateral relationship between China and the Philippines.

The Tribunal's observation that the Eritrea/Yemen tribunal considered artisanal fishing rights is vesting only in private individuals, rather than States, is also questionable. In Eritrea/Yemen, the tribunal observed that the "traditional fishing regime" in the Red Sea applied to the mutual relations between the two States concerned, beyond the fishermen as "immediate beneficiaries". 360 Moreover, it is clear that traditional fishing rights themselves can vest in the coastal State as a matter of international law. Thus, in Fisheries Jurisdiction (United Kingdom v. Iceland), the ICJ stated that "in order to reach an equitable solution of the present dispute it is necessary that the preferential fishing rights of Iceland, as a State specially dependent on coastal fisheries, be reconciled with the traditional fishing rights of the [United Kingdom]". ${ }^{361}$ Moreover, in some situations (such as the Jan Mayen case), the extent and importance of fishing activity will be sufficient to shift a maritime boundary in the coastal State's favour.

Furthermore, as highlighted by the Chinese Society of International Law, the only provision in UNCLOS which mentions traditional fishing rights, Article 51(1), treats those rights as rights of the States:

an archipelagic State shall respect existing agreements with other States and shall recognize traditional fishing rights and other legitimate activities of the immediately adjacent neighbouring States ...

Since the Tribunal's analysis was restricted to artisanal fishing rights enjoyed by individual Filipino (and Chinese) fishermen, its findings with respect to China's interference with Filipino fishing at Scarborough Shoal did not extend to any traditional fishing rights that maybe enjoyed by the State. For the reasons explained at Section II above, the Tribunal's conclusion that States' historical rights under customary international law were "superseded", and thus effectively wiped out, by UNCLOS is probably wrong.

Incidentally, Professor Talmon notes that "[i]n Submission No. 10 the Philippines [...] did not claim a violation of its own rights under the Convention and general international law but a violation of the rights of its citizens - the Filipino fishermen". ${ }^{362} \mathrm{He}$ concludes that the Philippines "brought a claim on

\footnotetext{
$360 \quad I d$. at para. 93 .

361 Fisheries, supra note 38 , at para. 69 .

362 Talmon, supra note 33, at para. 187.
} 
behalf of its citizen fishermen by way of diplomatic protection" and that this claim would accordingly be submitted to the rule of exhaustion of local remedies contained in UNCLOS at Article 295 - which the Tribunal did not raise in its Award on Jurisdiction. ${ }^{363}$ If traditional fishing rights are to be treated exclusively as private rights - as the Tribunal appears to have assumed - then we concur with Professor Talmon that the rule on the exhaustion of local remedies would apply, and should have been considered by the Tribunal.

4.4.3 The Tribunal's Recognition of Traditional Artisanal Fishing Rights at Scarborough Shoal

The Tribunal adopted a restrictive approach in determining that traditional fishing rights existed around Scarborough Shoal. In particular, its legal and factual analysis of the traditional fishing rights of Filipino fishermen focused exclusively on the artisanal aspect of those rights, as opposed to the extent to which such rights vested more broadly in the coastal State.

The Tribunal considered that:

[t]he legal basis for protecting artisanal fishing stems from the notion of vested rights and the understanding that, having pursued a livelihood through artisanal fishing over an extended period, generations of fishermen have acquired a right, akin to property, in the ability to continue to fish in the manner of their forebears. Thus, traditional fishing rights extend to artisanal fishing that is carried out largely in keeping with the longstanding practice of community, in other words to "those entitlements that all fishermen have exercised continuously through ages". 364

It further held that:

traditional fishing rights are customary rights, acquired through long usage, $[. .$.$] that the methods of fishing protected under international law$ would be those that broadly follow the manner of fishing carried out for generations: in other words, artisanal fishing in keeping with the traditions and customs of the region. ${ }^{365}$

363 Id. at paras. $187-92$.

364 Award, supra note 1, at para. 798.

365 Id. at para. 806. 
The importance of the temporal aspect of traditional artisanal fishing rights was highlighted in Eritrea v. Yemen, where the tribunal explained that "[t]he traditional fishing regime covers those entitlements that all the fishermen have exercised continuously through the ages". ${ }^{366}$ That tribunal recognised traditional artisanal fishing rights in a situation where there was "abundant literature on the historical realities which characterized the lives of the populations" and a "well-established factual situation reflected in deeply rooted common legal traditions which prevailed during several centuries". ${ }^{367}$ In the tribunal's opinion, "What was relevant was that fishermen from both of these nations had, from time immemorial, used these islands for fishing and activities related thereto." 368

In the vicinity of Scarborough Shoal, the Tribunal determined that "there was evidence that the surrounding waters have continued to serve as traditional fishing grounds for fishermen, including those from the Philippines, Viet Nam, and China (including Taiwan)". ${ }^{369}$ It also accepted that "the claims of both the Philippines and China to have traditionally fished at the shoal are accurate and advanced in good faith". ${ }^{370}$

In reaching this conclusion, the Tribunal noted that:

the stories of most of those who have fished at Scarborough Shoal in generations past have not been the subject of written records; ;71

traditional fishing rights constitute an area where matters of evidence should be approached with sensitivity; 372

it "does not have before it extensive details of the fishing methods traditionally used by either Filipino or Chinese fishermen, or of the communities that have traditionally dispatched vessels to Scarborough Shoal"; 373 and

it was "not prepared to specify any precise threshold for the fishing methods that would qualify as artisanal fishing". ${ }^{374}$

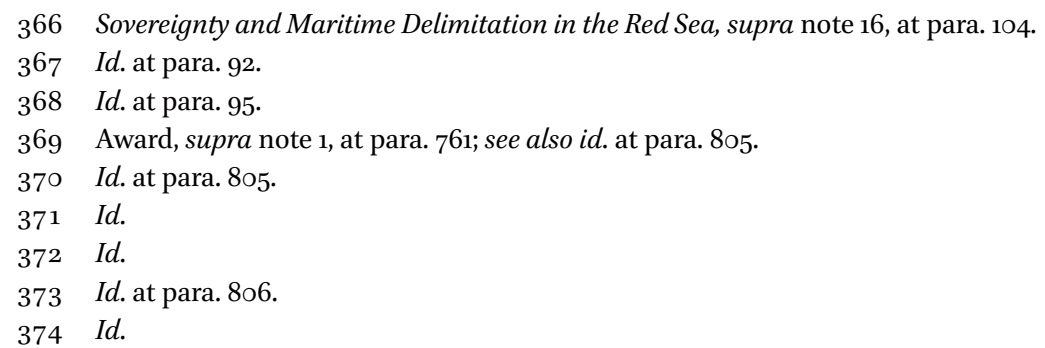


Despite these reservations as to the factual and evidentiary basis for establishing traditional artisanal fishing rights, the Tribunal concluded that it "was of the view that at least some of the fishing carried out at Scarborough Shoal has been of a traditional, artisanal nature". ${ }^{375}$

The Tribunal's finding of traditional artisanal fishing around Scarborough Shoal was thus reached without having conducted a full examination as to whether a tradition (i.e. the temporal aspect) had been established and, once more, on the basis of sparse evidence. In this respect also, the Award is distinguishable from the Eritrea/Yemen case, where the existence of continuous fishing "through the ages" was clear.

By contrast, in concluding that Filipino traditional artisanal fishing rights existed around Scarborough Shoal, the Tribunal referred only to an extract from a 1953 book published by the Philippines Bureau of Fisheries and an article from the Philippines Farmers Journal of 1960 allegedly depicting "Scarborough Shoal as having historically served as one of the 'principle fishing areas' for Filipino fishermen". ${ }^{376}$ Neither of these documents categorically establishes the existence of traditional Filipino fishing around Scarborough Shoal "through the ages". 377

The Tribunal also referred to a Memorandum from the Philippines Navy of April 2012 that described Scarborough Shoal as "a traditional fishing ground of fishermen from neighbouring Asian countries" and stated that "[b]oth foreign and local fishermen are among those who venture to this atoll".378 This statement, produced by the Philippines less than a year before it commenced the arbitration, equally cannot confirm or establish Filipino traditional artisanal fishing at Scarborough Shoal. 379

The Tribunal finally referred to the affidavits of six Filipino fishermen which, according to the Tribunal, "provid[ed] direct documentation of Philippines fishing activities in the area at least since 1982 and indirect evidence from

\footnotetext{
375 Id. at para. 807 .

376 Id. at para. 762; P. Manacop, The Principal Marine Fisheries, in Philippine Fisheries: Handbook Prepared by the Technical Staff of the Bureau of Fisheries 103, 121 (D.V. Villadolid ed., 1953) (Annex 8); A.M. Mane, Status, Problems and Prospects of the Philippine Fisheries Industry, 2(4) Philippine Farmers Journal 32, 34 (1960) (Annex 244).

377 Award, supra note 1, at para. 798 (referring to Eritrea v. Yemen, Award, 17 December 1999 at para. 104).

378 Id. at para. 761 (referring to Memorandum from Colonel, Philippine Navy, to Chief of Staff, Armed Forces of the Philippines, No. N2E-0412-0o8 (April 2012) (Annex 77)).

379 Critical Study, supra note 84, at para. 762 .
} 
1972". 380 These affidavits were key to the Tribunal's finding of "traditional, artisanal nature" fishing at Scarborough Shoal. It was these affidavits which formed the foundation for the Tribunal's conclusion that "at least some of the fishing carried out at Scarborough Shoal has been of a traditional, artisanal nature". 381

The Award's finding with respect to the existence of traditional artisanal fishing by Filipino fishermen at Scarborough Shoal is therefore based on a limited evidentiary record. It is also unduly restrictive in focusing on traditional artisanal fishing rights (enjoyed by the individual) and excluding the possibility of traditional fishing rights enjoyed by the State.

We note that the Tribunal found that Chinese fishermen equally enjoy traditional artisanal fishing rights around Scarborough Shoal. ${ }^{382}$ As explained above, however, the Tribunal was probably mistaken to exclude the possibility of Chinese artisanal fishing rights extending beyond the 12-mile limit around Scarborough Shoal.

\section{$4 \cdot 5$}

The Tribunal's Finding that, with Respect to the Protection and Preservation of the Marine Environment in the South China Sea, China Breached Its Obligations under Articles 123, 192, 194(1), 194(5), 197, and 206 of UNCLOS (Philippines Submissions Nos. 11 and 12(b); Tribunal Merits Dispositif Nos. 12 and 13)

The Tribunal found that, with respect to the harvesting of endangered species, China had breached its obligations under Articles 192 and 194(5) of UNCLOS. ${ }^{383}$ It further found that, with respect to construction activities on seven reefs in the Spratly Islands, China had breached its obligations under Articles 123, 192, 194(1), 194(5), 197 and 206 of UNCLOS. ${ }^{384}$

\footnotetext{
$380 \quad$ Award, supra note 1, at paras. 763,807 .

381 Id. at para. 807. The Tribunal also relied on a report from FRPLEU/QRT Officers, Bureau of Fisheries and Aquatic Resources, Republic of the Philippines, to the Director, Bureau of Fisheries and Aquatic Resources, Republic of the Philippines (2 May 2012) (Annex 80). Nevertheless, this article mainly relates to the activities of Chinese fishermen.

$382 \quad I d$. at paras. $805^{-0} 7$.

$383 \quad I d$. at merits dispositif no. 12 .

384 Id. at merits dispositif no. 13 .
} 
4.5.1 The Tribunal's Finding with Respect to the Harvesting of Endangered Species

The Tribunal declared that "China has breached its obligations under Articles 192 and 194(5) of [UNCLOS]" based on the following findings:

that fishermen from Chinese flagged vessels have engaged in the harvesting of endangered species on a significant scale;

that fishermen from Chinese flagged vessels have engaged in the harvesting of giant clams in a manner that is severally destructive of the coral reef ecosystem; and

that China was aware of, tolerated, protected, and failed to prevent the aforementioned harmful activities.... ${ }^{385}$

The Tribunal found no breaches by China with respect to the alleged use by Chinese fishermen of explosives and cyanide at Scarborough and Second Thomas Shoal. It considered that there was "scant evidence in the case record [of such practices] over the last decade or Philippine complaints about its use", which suggested that China "may have taken measures to prevent such practices in the Spratly Islands". ${ }^{386}$

4.5.1.1 The Tribunal's Finding that China Breached Its Obligations under Articles 192 and 194(5) of UNCLOS to Take Necessary Measures to Protect and Preserve the Marine Environment with Respect to the Harvesting of Endangered Species from the Fragile Ecosystems at Scarborough Shoal and Second Thomas Shoal

The Tribunal found that "fishermen from Chinese flagged vessels have engaged in the harvesting of endangered species on a significant scale". ${ }^{387}$ It listed various instances in or at Scarborough Shoal between 1998 and 2012, ${ }^{388}$ and one instance at Second Thomas Shoal in May 2013. ${ }^{389}$ The Tribunal also noted that "recent evidence indicates the large-scale harvest of endangered hawksbill sea turtles by Chinese fishermen, whose arrest by Philippine authorities led to

385 Id. at merits' dispositif no. 12; see also id. at para. 992.

386 Id. at para. 975 .

387 Id. at merits' dispositif no. 12(a); see also id. at para. 95०.

388 Id. at para. $95^{\circ}$.

389 Id. at para. 951. 
protest by China". ${ }^{390}$ In the absence of contradictory evidence, we see no basis on which to challenge these factual findings.

The Tribunal also held that it had "no hesitation" in finding that China breached its obligations under Articles 192 and 194(5) of UNCLOS to take the necessary measures to protect and preserve the maritime environment. ${ }^{391} \mathrm{It}$ reached this conclusion in two steps.

First, the Tribunal considered that China was aware of the poaching practice by Chinese vessels, ${ }^{392}$ and that there was "no evidence in the record that would indicate that China has taken any steps to enforce [...] rules and measures [including CiTes, to which China is a party, and China's 1989 Law of the Protection of Wildlife] against fishermen engaged in poaching of endangered species". 393

While not on the record (due to China's non-participation), publicly available evidence did exist to show that China had taken certain measures to prevent the illegal harvesting of endangered species in the South China Sea. The Critical Study of the Chinese Society of International Law refers to some examples, including: (i) the adoption of joint law enforcement actions by various governmental entities in June 2003 and June $2012 ;{ }^{394}$ (ii) the adoption by the Qionghai City and Tanmen Town in Hainan province in March 2015 of an "Implementation Program for Carrying out the Special Inspection for Combating Illegal Acts such as Dredging, Transporting and Selling of Giant

$390 \quad I d$. at para. 952 .

$391 \quad I d$. at para. 964.

392 Id. at paras. $962-63$.

393 Id. at para. 964. See also id. at para. 915: "the Tribunal has seen no evidence that Chinese fishermen involved in poaching of endangered species have been prosecuted under Chinese law".

394 Critical Study, supra note 84, at para. 797. As noted by the Chinese Society of International Law, "on 25 June 2003, Ministry of Agriculture, State Administration for Industry and Commerce, General Administration of Customs and Ministry of Public Security jointly started a special law enforcement program to penalize illegal hunting, killing, purchasing, selling, transporting, importing and exporting aquatic wild animals"; and "[o]n 28 June 2012, Ministry of Agriculture, Ministry of Public Security and General Administration of Customs organized another special law enforcement program to combat illegal harvesting, trading and utilizing, and smuggling of aquatic wild animals", referring to xinhuanet.com articles, China's Ministry of Agriculture: a Special Action will be launched to save aquatic wild animals, http://news.xinhuanet.com/news center/2003-06/25/content_937686.htm; Wildlife conservation office of China's Ministry of Agriculture: joint law enforcement will be conducted by China's several Ministries for aquatic wild animal protection, http://news.xinhuanet.com/politics/2012-06/28/c_. 
Clams"; 395 and (iii) at least two cases in which Chinese fishermen were arrested, prosecuted and imprisoned. ${ }^{396}$

The evidence of enforcement measures and prosecutions in the specific areas at issue is however relatively sparse, particularly when contrasted against the evidence of widespread illegal and damaging activities in those areas upon which the Tribunal relied. ${ }^{397}$ We therefore consider that this would do little to disprove the Tribunal's conclusion.

Second, the Tribunal considered that, at least for the April 2012 incidents, the evidence in fact "points directly to the contrary", i.e., in its opinion, China protected and tolerated the harvesting of giant clams. ${ }^{398}$ The Tribunal relied on various pieces of contemporaneous evidence, including photographic evidence, in reaching its conclusion that "China must have known and deliberately tolerated, and protected the harmful acts". 399

In the absence of contradictory evidence, we see no basis on which to challenge the Tribunal's conclusions in these respects.

395 Id. at para. 799. As noted by the Chinese Society of International Law, Qionghai City of Hainan province and the local government of Tanmen Town have respectively issued and formulated such programs (see Implementation Program for Carrying out the Special Law Enforcement Inspection for Combating Illegal Dredging, Transporting and Selling of Giant Clams in Qionghai City, http://xxgk.hainan.gov.cn/qhxxgk/bgt/201503/t20150326_1539023 .htm and Implementation Program for Carrying out the Special Inspection for Combating Illegal Acts such as Dredging, Transporting and Selling of Giant Clams, http://xxgk .hainan.gov.cn/qhxxgk/tmz/201509/t20150925_1672393.htm). Through these programs the Qionhai city and the Tanmen town are willing to "implement the Law of the [PRC] on the Protection of Wild Animals and other relevant laws and regulations, and further strengthen the protection of aquatic animal resources, and maintain a balanced development of the marine ecological environment". The programs target, inter alia, fishing vessels which illegally collected shells from the Spratly Islands and Scarborough Shoal.

396 Id. at para. 8oo. The Chinese Society of International Law reports two cases where the harvesting of endangered species happened in the South China Sea. In the first case, "Li, Fu and Yang were arrested [on 3 December 2007] for illegal purchasing, transporting, selling sea turtles, and subsequently prosecuted and punished by a People's Court in the suburban areas of Sanya City, Hainan Province", citing Three persons were sentenced to imprisonment from 9 months to 2 years respectively for purchasing, transporting, and selling 54 sea turtles, http://www.hi.chinanews.com/hnnew/2008-08-07/121212.html. The press article reports that the fishermen illegally caught sea turtles in the Nansha sea. In the second case, "Yao was arrested [in May 2004] for illegal selling of red corals products, and subsequently sentenced to imprisonment by a People's Court in Guangzhou City, Guangdong Province".

397 Award, supra note 1, at paras. 950-53.

398 Id. at para. 964.

399 Id. 
More generally, we consider that given the nature of the "due diligence" obligations enshrined in Articles 192 and 194(5) of UNCLOS, the Tribunal's conclusion of a violation of these Articles was correct, regardless of whether or not China "tolerated" or "protected" the harmful activities. These articles respectively provide that "States have the obligation to protect and preserve the marine environment" and that the measures taken "shall include those necessary to protect and preserve rare or fragile ecosystems as well as the habitat of depleted, threatened or endangered species and other forms of marine life". The Tribunal's findings about the China's alleged "tolerance" and "protection" were incidental, given its finding that China had failed to take such necessary measures to protect and preserve the maritime environment.

\subsubsection{The Tribunal's Finding that China Breached Its Obligation to Protect and Preserve the Marine Environment in Respect of Its Toleration and Protection of the Harvesting of Giant Clams by the Propeller Chopping Method}

The Tribunal established that "fishermen from Chinese flagged vessels have engaged in the harvesting of giant clams in a manner that is severally destructive of the coral reef ecosystem". ${ }^{400}$ It held that the Tribunal was "satisfied based on its review of satellite imagery, photographic and video evidence, contemporaneous press reports, scientific studies and the materials from Professor Mc Manus, that in recent years, Chinese fishing vessels have been engaged in widespread harvesting of giant clams through the use of boat propellers to break through the coral substrate in search of buried clam shells". 401

The Tribunal then considered that "the small propellers vessels involved in harvesting the giant clams were within China's jurisdiction and control".402 It found that "China, despite its rules on the protection of giant clams, and on the preservation of the coral reef environment generally, was fully aware of the practice and has actively tolerated it as a means to exploit the living resources of the reefs in the months prior to those reefs succumbing to the near permanent destruction brought about by the island-building activities". 403

The Tribunal overtly based its conclusion on: (i) the Ferse Report; (ii) the McManus Report; and (iii) an article from the website The Diplomat. Yet neither the Ferse Report nor the McManus Report refer to China's awareness or "active tolerance" of this practice. The Tribunal's fundamental finding is thus primarily

\footnotetext{
$400 \quad I d$. at merits dispositif no. $12(\mathrm{~b})$.

401 Id. at para. $953,957-58$.

402 Id. at para. 965 .

403 Id.
} 
based on an article from the website The Diplomat. ${ }^{404}$ Notwithstanding the limited evidence, we see no basis on which to challenge the Tribunal's finding in the absence of any evidence to the contrary.

4.5.2 The Tribunal's Finding with Respect to Construction Activities on Seven Reefs in the Spratly Islands

The Tribunal declared that "China has breached its obligations under Articles 123, 192, 194(1), 194(5), 197, and 206 of the Convention" based on the following findings:

... China's land reclamation and construction of artificial islands, installations, and structures at Cuarteron Reef, Fiery Cross Reef, Gaven Reef (North), Johnson Reef, Hughes Reef, Subi Reef, and Mischief Reef has caused severe, irreparable harm to the coral reef ecosystem;

[...] China has not cooperated or coordinated with the other States bordering the South China Sea concerning the protection and preservation of the marine environment concerning such activities; and

[...] China has failed to communicate an assessment of the potential effects of such activities on the marine environment, within the meaning of Article 206 of the Convention. ${ }^{405}$

\subsubsection{The Tribunal's Position on China's Obligation to Cooperate or Coordinate with Other States Bordering the South China Sea}

The Tribunal held that, "[w]ith respect to China's island-building program", it had before it "no convincing evidence of China attempting to cooperate or coordinate with the other States bordering the South China Sea". ${ }^{406}$ It consequently found a breach of Articles 197 and 123 of UNCLOs. 407

ITLOS has declared the duty to cooperate a fundamental principle of international law. ${ }^{408}$ Nevertheless, the precise scope of that duty is dependent on

404 V.R. Lee, Satellite Imagery Shows Ecocide in the South China Sea, The Diplomat (15 January 2016), https://thediplomat.com/2016/o1/satellite-images-show-ecocide-in-the -south-china-sea/. According to this article, there "is abundant evidence that China's navy and coast guard have been aware of the Tanmen fishermen's practice of chopping reefs, and tolerated or condoned it".

405 Award, supra note 1, at merits dispositif no. 13.

406 Id. at para. 986.

407 Id. at merits dispositif no. 13.

408 Mox Plant Case (Ireland v. U.K.), Case No. 10, Order of Dec. 3, 2001, ITLOS Rep. 82: "the duty to cooperate is a fundamental principle in the prevention of pollution of the marine environment under Part XII of the Convention and general international law"; Land Reclamation by Singapore in and around the Straits of Johor (Malaysia v. Singapore), Case 
the specific nature of each relevant regime. ${ }^{409}$ We understand in this context that the Chinese language version of Article 197 enumerates a duty that is potentially more restrictive than that contained in the English language version. ${ }^{410}$ Had the Tribunal reviewed (and taken account of) that different understanding of the duty contained in Article 197, then it may have reached a different conclusion as to the scope of the obligation and, consequently, China's breach. It goes without saying that the various official language versions of UnCLOS (in Arabic, Chinese, English, French, Russian and Spanish) are all equally authentic (Article 320), and there is thus no reason to prefer the English over the Chinese. ${ }^{411}$

The Tribunal's finding in any case overlooks the fact that China appears to have undertaken various initiatives at the multilateral level to enhance cooperation on marine environmental protection. ${ }^{412}$ For example, China and

No. 12, Order of Oct. 8, 2003, ITLOS Rep. 92; Request for an Advisory Opinion Submitted by the Sub-Regional Fisheries Commission (SRFC), Case No. 21, Advisory Opinion of Apr. 2, 2013, ITLOS Rep. 140.

409 See Robert Steenkamp, UNCLOS, CITES and the IWC - A Tailored International Duty to Cooperate? EJIL:TALK (6 November 2018), https://www.ejiltalk.org/unclos-cites-and-the -iwc-a-tailored-international-duty-to-cooperate/.

410 Article 197 of UNCLOS, in English, provides that: "States shall cooperate on a global basis and, as appropriate, on a regional basis, directly or through competent international organizations, in formulating and elaborating international rules, standards and recommended practices and procedures consistent with this Convention, for the protection and preservation of the marine environment, taking into account characteristic regional features".

The English translation of the Chinese version of this Article reads as follows: "When formulating and elaborating international rules, standards and recommended practices and procedures consistent with this Convention in order to protect and preserve the marine environment, states shall co-operate on a global basis and, as appropriate, on a regional basis, directly or through competent international organizations, and take into account characteristic regional features".

These two provisions clearly differ: while the English language version enumerates a general duty to cooperate, the Chinese language version appears only to attach such duty to circumstances where States choose to "formulat $[\mathrm{e}]$ and elaborate[e] international rules, standards and recommended practices and procedures consistent with this Convention".

411 We note, however, that the French and Spanish language versions are more similar in meaning to the English than the Chinese, lending weight to a preference for adopting the former's scope of obligation. We have not reviewed the Arabic and Russian language versions.

412 Critical Study, supra note 84, at para. 814. The Chinese Society of International Law refers, inter alia, to China's establishment in 2011 of the "China-ASEAN Maritime Fund" and to the adoption of the "Cooperation Framework Plan on the South China Sea and 
the Philippines both participated in the 'Action Plan for the Protection and Development of the Marine Environment and Coastal Areas of the East Asian Seas Region' (including the South China Sea). ${ }^{413}$ This Action Plan covers, inter alia, the protection of the marine and coastal environment and is steered by a Coordinating Body on the Seas of East of Asia (COBSEA).

The question remains as to whether such evidence, if before the Tribunal, would have been sufficient to alter its conclusion. In isolation, this seems unlikely. The Tribunal seemed to be looking for specific evidence of cooperation "with respect to China island-buildings program". ${ }^{414}$ In the MoX Plant case, the duty to cooperate was interpreted by ITLOs to include an obligation to exchange information on the risks or effects of an activity that could potentially harm the other state. ${ }^{415}$ Furthermore, as pointed out by the Tribunal, in the ICJ's Pulp Mills on the River Uruguay case, the Court noted that "by cooperating $[\ldots]$ the States concerned can manage the risks of damage to the environment that might be created by the plan initiated by one or [the] other of them, so as to prevent the damage in question".416 Therefore, evidence of a more compelling nature would show that China also cooperated and coordinated with other States bordering the South China Sea with respect to its reclamation and construction activities on the seven features themselves. ${ }^{417}$

its Surrounding Waters (2011-2015)" published by the SOA, which focused, inter alia, on marine environmental protection and marine ecosystem and biological diversity. China had engaged in bilateral co-operation on marine environmental protection with littoral countries such as Thailand, Cambodia and Indonesia.

413 See совSEA, https://www.cobsea.org/aboutcobsea/background.html.

414 Award, supra note 1, at para. 986.

415 Mox Plant Case, supra note 408, at para. 84. See also dispositive, supra note 288 at 110-11: the tribunal prescribed, inter alia, that "Ireland and United Kingdom shall cooperate and shall, for this purpose, enter into consultations forthwith in order to (a) exchange further information with regard to possible consequences for the Irish Sea arising out of the commissioning of the mox plant [...]". On the duty of prior information and the duty to cooperate, see also Land Reclamation Case, supra note 408, at paras. 92, 99.

416 Award, supra note 1, at para. 987 (referring to Pulp Mills on the River Uruguay (Arg. v. Uru.), Judgment, 2010 I.C.J. Rep. 14, ๆ 77 (Apr. 20)).

417 We also note that the Tribunal stated that "Throughout the course of China's islandbuilding project, in multiple exchanges of diplomatic notes, the Philippines has strongly protested China's activities and China has rejected 'the groundless protest and accusation' by the Philippines. China has also pointed out that 'the Philippine side has constructed and kept expanding facilities including airports, harbors, stilt houses and schools on some of the illegally occupied islands and reefs"'. Award, supra note 1, at para. 859 . 


\subsubsection{The Tribunal's Position on China's Obligation to Assess and Communicate the Environmental Impacts of the Constructions}

Relying on Article 206 UNCLOs, the Tribunal considered that "given the scale and impact of the island-building activities [...], China could not reasonably have held any belief other than that the construction 'may cause significant and harmful changes to the marine environment". 418 It considered that "China was required, 'as far as practicable', to prepare an environmental impact assessment" and that "[i]t was also under an obligation to communicate the results of the assessment". 419

The Tribunal held that, while it could not make a definitive finding that China had not prepared an environmental impact assessment, "[t]o fulfil the obligations of Article 206, a State must not only prepare an EIA but also communicate it". 420

The Tribunal held that China had "delivered no assessment in writing to [competent international organisations] or any other international body as far as the Tribunal is aware". ${ }^{211}$ It concluded that "China ha[d] not fulfilled its duties under Article 206 of the Convention".422 In the absence of contradictory evidence, we see no basis on which to challenge this conclusion. ${ }^{423}$

\subsection{The Tribunal's Finding that, through Its Construction of Artificial Islands, Installations and Structures at Mischief Reef, China Breached Articles 6o and 80 of UNCLOS (Philippines Submission No. 12(A) and (C); Tribunal Merits Dispositif No. 14)}

With regard to this submission, the Tribunal first found that "China has engaged in the construction of artificial islands, installations, and structures at

\footnotetext{
418 Award, supra note 1, at para. 988.

419 Id.

$420 \quad I d$. at para. 991.

421 Id.

422 Id.

423 We note that during the Hearing on Merits, the Tribunal asked the Philippines if it was "aware of any experts from China or elsewhere that have published or articulated views about the environmental impact of China's activities or toleration of activities by others within its control that are contrary or different to those of the Philippines". Id. at para. 921. As explained in the Award, the Philippines explained that "its searches had turned up only 'a brief statement from the State Oceanic Administration'". Id. at para. 921. The Tribunal also invited the Chinese Government "to indicate whether it has conducted an environmental impact study as per Article 206 of the Convention and, if so, to provide the Tribunal with a copy" and that "China did not respond to the Tribunal's request". Id. at para. 924 .
} 
Mischief Reef without the authorisation of the Philippines". ${ }^{424}$ It then recalled "(i) its finding that Mischief Reef is a low-tide elevation, (ii) its declaration that low-tide elevations are not capable of appropriation, and (iii) its declaration that Mischief Reef is within the exclusive economic zone and continental shelf of the Philippines".425 The Tribunal finally declared that "China has breached Articles 60 and 80 of the Convention with respect to the Philippines' sovereign rights in its [EEZ] and continental shelf". ${ }^{26}$

Subject to the jurisdictional concerns raised in Section IV.A(i) above, we have no further comments on the Tribunal's findings with respect to the Philippines' Submission no. 12.

\subsection{The Tribunal's Finding that China's Operation of Its Law Enforcement Vessels Violated COLREGs and, as a Consequence, Breached Article 94 of UNCLOS (Philippines Submission No. 13; Tribunal Merits Dispositif No. 15)}

The Tribunal found that China's operation of its law enforcement vessels in the vicinity of Scarborough Shoal on 28 April 2012 and 26 May 2012: "created serious risk of collision and danger to Philippine ships and personnel; and ... violated Rules 2, 6, 7, 8, 15, and 16 [COLREGS]".427

The Tribunal accordingly declared that "China has breached its obligations under Article 94 of the Convention". ${ }^{428}$

\subsubsection{The Tribunal's Application of COLREgS and Article 94 UNCLOS} The Tribunal upheld the Philippines' position that the COlREgs is "one of the 'general accepted international regulations' to which flag States are required to conform". 429 It held that "Article 94 incorporates the COLREGS into the Convention, and they are consequently binding on China".430 The Tribunal concluded that "a violation of the COLREGS, as 'generally accepted international regulations' concerning measures necessary to ensure maritime safety, constitutes a violation of [UNCLOS] itself". 431 Although the Tribunal did not explain how it came to final conclusion, we consider that it was probably correct on the law. Article 94(5) of UnCLOS provides that "[i]n taking the

\footnotetext{
424 Award, supra note 1, at merits dispositif no. 14.

425 Id.

426 Id.

427 Id. at merits dispositif no. 15 .

428 Id.

429 Id. at para. 1063.

430 Id. at para. 1083.

431 Id.
} 
measures called for in paragraphs 3 and 4 each State is required to conform to generally accepted international regulations, procedures and practices and to take any steps which may be necessary to secure their observance". This Article "effectively incorporates by reference obligations found in other treaties or non-binding instruments, and gives them the force of a treaty obligation under UNCLOS (so-called 'rules of references')". ${ }^{332}$ Furthermore, "[c]ommentators generally agree that ... the [COLREGs] qualify" as such "generally accepted international regulations". 433

Some commentators have nevertheless raised the question of the applicability of the COLREGS in the circumstances of the South China Sea arbitration. For example, the Tribunal observed that the dispute related "principally to events that occurred in the territorial sea" of Scarborough Shoal. ${ }^{434}$ However, as noted by Whomersley and the Chinese Society of International Law, Article 94 is contained in Part VII of UNCLOS which is entitled "High Seas". 435 Whomersley considers that "the presumption must [therefore] be that [Article 94] only applies on the high seas". ${ }^{36}$ We consider this to be a sound argument. After all, Article 86 (which introduces Part VII of UNCLOS) provides in pertinent part that:

The provisions of this Part apply to all parts of the sea that are not included in the exclusive economic zone, in the territorial sea or in the internal waters of a State, or in the archipelagic waters of an archipelagic State.

This criticism of the Award is also supported by commentators to UNCLOS, who note that "Article 94 sets out the duties of the flag State with regard to ships flying its flag ... [i]n that context, it provides for flag State investigation

432 Alexander Proelss (eds.), Commentary under Article 94, United Convention on the LaW of the Sea, A Commentary (2017), at para. 11.

433 Id. (referring to J. Harrison, Making the Law of the Sea: A Study in the Development of International Law 161-62 (2011)); Robin R. Churchill \& Alan V. Lowe, The Law OF THE SeA 265-72 (3rd ed. 1999); Donald R. Rothwell \& Tim Stephens, The International LaW of the Sea 359-62 (2d ed. 2016). See also International Maritime Organization, Implications of the United Nations Convention on the Law of the Sea for the International Maritime Organization, Doc. LEG/MISC.8, 30 January 2014, in which the Imo lists the COLREGS as regulations that "on account of their worldwide acceptance, [may] be deemed to fulfil the general acceptance requirement".

434 Award, supra note 1, at para. 1045 .

435 Whomersley, supra note 354 , at para. 65; see also Critical Study, supra note 84, at para. 836 .

436 Id. 
where proper jurisdiction and control have not been exercised, and for inquiry into every marine casualty or incident of navigation on the high seas". ${ }^{437}$ It is also supported by the fact that Article 21(4) of UNCLOS separately addresses the question of the application of the COLREGS to foreign ships exercising the right of innocent passage through the territorial sea. ${ }^{438}$ In parallel, Article 25(1) of UNCLOS safeguards the coastal State's right to "take the necessary steps in its territorial sea to prevent passage which is not innocent".

Whomersley also raises the question as to whether the COLREGS should have applied in circumstances where "the vessels involved were Chinese law enforcement vessels engaged in official activities in what China considers, and the Tribunal assumed, to be within Chinese jurisdiction". 439 He argues that, in such circumstances, "the normal rules of navigation cannot apply". 440 This is another credible line of argument. Whomersley considers that "one would naturally look to other rules of international law to regulate the activities of vessels engaged in law enforcement activities" and that IT LOS' MV Saiga (No. 2) case "ought to have been the yardstick against which the Tribunal should have measured the acceptability of the actions of the Chinese vessels". ${ }^{441}$

In $M V$ Saiga (No. 2), ITLOS stated that "[a]lthough [UNCLOS] does not contain express provisions on the use of force in the arrest of ships, international law, which is applicable by virtue of article 293 of the Convention, requires that the use of force must be avoided as far as possible and, where force is unavoidable, it must not go beyond what is reasonable and necessary in the circumstances." 442

ITLOS recalled that " $t$ t]hese principles have been followed over the years in law enforcement operations at sea". ${ }^{443}$ It further explained that:

The normal practice used to stop a ship at sea is first to give an auditory or visual signal to stop, using internationally recognized signals. Where this does not succeed, a variety of actions may be taken, including the firing of shots across the bows of the ship. It is only after the appropriate

437 Myron H. Nordquist et al. (eds.), United Nations Convention on the LaW of the SeA, 1982: A Commentary Article 94, para. 94.1.

438 Article 21(4) UNCLOS provides that "[f] oreign ships exercising the right of innocent passage through the territorial sea shall comply with all such laws and regulations and all generally accepted international regulations relating to the prevention of collisions at sea".

439 Whomersley, supra note 354 , at para. 62.

$440 \quad I d$.

441 Id.

442 The $M / V$ "Saiga", supra note 63, at para. 155.

443 Id. at para. 156. 
actions fail that the pursuing vessel may, as a last resort, use force. Even then, appropriate warning must be issued to the ship and all efforts should be made to ensure that life is not endangered (S.S. "I'm Alone" case (Canada/United States, 1935), U.N.R.I.A.A., Vol. III, p. 16og; The Red Crusader case (Commission of Enquiry, Denmark - United Kingdom, 1962), I.L.R., Vol. 35, p. 485$).{ }^{444}$

ITLOS concluded that:

[t]he basic principle concerning the use of force in the arrest of a ship at sea has been reaffirmed by the Agreement for the Implementation of the Provisions of the United Nations Convention on the Law of the Sea [...]: (1) The inspecting State shall ensure that its duly authorized inspectors: ... (f) avoid the use of force except when and to the degree necessary to ensure the safety of the inspectors and where the inspectors are obstructed in the execution of their duties. The degree of force used shall not exceed that reasonably required in the circumstances. ${ }^{445}$

Whomersley finally raises the question as to whether "China was under an obligation under UNCLOS to apply the COLREGS to Chinese flag vessels in the territorial sea of a feature which is assumed to be under its sovereignty".446 Based on the above analysis of Article 94 and on the fact that Article 21(4) UNCLOS only applies to "foreign ships exercising the right of innocent passage", he considers that "there is nothing in UNCLOS to place an obligation on a State to apply the COLREGS to its own flag vessels in its own territorial sea".447 Again, this seems to us a sound argument. Moreover, the Tribunal would have had no jurisdiction to consider whether or not Chinese activities violated Article 21(4) or 25(1) of UNCLOS, as to do so would have required an assessment of sovereignty over Scarborough Shoal.

4.7.2 The Tribunal's Finding of a Breach of COLREGS

The Tribunal's factual understanding and account of events were based on two documents submitted by the Philippines: (i) a report from the Philippines Coast Guard (SARV Coastguard Report of 28 April 2012); and (ii) a report from the Bureau of Fisheries and Aquatic Resources of the Republic of Philippines

\footnotetext{
$444 I d$.

445 Id.

446 Whomersley, supra note 354, at para. 63 .

447 Id. at para. 66; see also Critical Study, supra note 84, at para. 844 .
} 
(Arunco Report of 28 May 2012). ${ }^{448}$ The Tribunal noted that "China has not made specific statements with respect to the incidents of 28 April and 26 May 2012" and that it did "not have explicit Chinese statements concerning the incidents alleged by the Philippines" in this submission. ${ }^{449}$

Similarly, the Philippines' expert report (the Allen Report) and the Tribunalappointed expert report (the Singhota Report) both relied on the facts described in those two documents, leading the Tribunal to conclude that China had "repeatedly violated the Rules of the COLREgs over the course of the interactions described by the crew of the Philippines vessels and as credibly assessed in the two expert reports". 450

In the absence of Chinese statements on these incidents, or evidence to the contrary, we consider that the experts and the Tribunal had no choice but to rely on these documents. Once more, however, the Tribunal's finding of a breach of Article 94 of UNCLOS was legally questionable, based on sparse evidence and related to singular isolated incidents.

\section{5}

\section{Procedural and Evidentiary Issues Arising from the Tribunal's Handling of the Merits Phase of the Arbitration}

\subsection{Introduction}

Like any international court or tribunal, the South China Sea Tribunal had to operate within the bounds of the Parties' consent and in accordance with applicable rules of procedure. One such fundamental rule of procedure is that each Party shall have the burden of proving the facts relied on to support its claim or defence. That fundamental obligation does not change simply because the respondent Party, China, did not appear in the proceedings. The unusual circumstance in which the Tribunal found itself meant that the Tribunal not only had to ensure that the Philippines carried its burden of proof, but that, additional, the Tribunal was satisfied that it has jurisdiction over the dispute and that the claim is well founded in fact and law.

\footnotetext{
448 Award, supra note 1, at paras. 1047-57 (referring to Report from the Commanding Officer, SARV-oo3, Philippine Coast Guard, to Commander, Coast Guard District Northwestern Luzon, Philippine Coast Guard (28 April 2012) (Annex 78), and Report from A.A. Arunco, et al., FRPLEU-QRT Officers, Bureau of Fisheries and Aquatic Resources, Republic of the Philippines, to the Director, Bureau of Fisheries and Aquatic Resources, Republic of the Philippines (28 May 2012) (Annex 82)).

449 Id. at para. 1080.

450 Id. at para. 1105.
} 
The Tribunal had to navigate a course that was consistent with these fundamental rules of procedure. Furthermore, the Tribunal also was bound to consider and implement applicable rules of international law, including with respect to due process and the principles espoused in the Monetary Gold case. As explained in this Section, aspects of the merits phase of the arbitration and the Tribunal's Merits Award are plagued by the Tribunal's failure properly to implement these rules of procedure and other rules of international law.

This section is set out as follows: Section 5.2 sets out a few striking anomalies in the Tribunal's assessment and application of evidence; Section $5 \cdot 3$ analyses whether the Tribunal provided the Parties with sufficient opportunities to examine its appointed experts; Section 5.4 analyses the Tribunal's exposition and application of the Monetary Gold principle; and Section 5.5 analyses whether the Merits Award satisfies the well-established principle that an award must state the reasons on which it is based.

\subsection{The Tribunal Relieved the Philippines of Its Burden of Proof}

This Section sets out a few striking anomalies in the Tribunal's assessment and application of evidence. Sub-section (i) explains important aspects of the Parties' burden of proof and the Tribunal's obligation to ensure that the claim is well founded in fact and law; Sub-section (ii) examines whether the Tribunal improperly relieved the Philippines of its burden of proof with respect to its Submissions No. 4 and 6; Sub-section (iii) examines whether the Tribunal afforded the Parties sufficient opportunity to examine the Tribunal-appointed experts and their reports; and Sub-section (iv) examines the Tribunal's conclusions in relation to China's failure to have due regard to the rights and duties of the Philippines in the vicinity of Mischief Reef.

\section{2 .1}

Rules in Relation to the Parties' Burden of Proof and the

Tribunal's Obligation to Ensure that the Claim is Well Founded in

Fact and Law

It is a well-established rule of law and principle of international adjudication that each party has the burden of proving its case. ${ }^{451}$ Ordinarily, international courts and tribunals are limited to assessing the evidence produced before them by the parties. ${ }^{452}$

451 See UnCitral Arbitration Rules, Article 24.1; ICDR International Arbitration Rules, Article 19.1.

$45^{2}$ See UnCitral Arbitration Rules, Article 25.6; ICDR International Arbitration Rules, Article 20.6; ICSID Arbitration Rules, Rule 34(1). 
Against the backdrop of these fundamental tenets of international dispute resolution, one would expect that, if the moving party's evidence is not reliable, the court or tribunal would decide that the moving party had not met its burden of proof. For example, the ICJ has usually exercised caution when faced with circumstances that would require it to engage proactively in factfinding exercises involving issues and questions of a technical nature. In the Case concerning Military and Paramilitary Activities in and against Nicaragua, the Court recognised that:

[a] situation of armed conflict is not the only one in which evidence of fact may be difficult to come by [...] ultimately, however, it is the litigant seeking to establish a fact who bears the burden of proving it. ${ }^{453}$

Similarly, in the Case concerning Pulp Mills on the River Uruguay, the Court concluded that:

... it is the responsibility of the Court, after having given careful consideration to all the evidence placed before it by the Parties, to determine which facts must be considered relevant, to assess their probative value, and to draw conclusions from them as appropriate. Thus, in keeping with its practice, the Court will make its own determination of the facts, on the basis of the evidence presented to it, and then it will apply the relevant rules of international law to those facts which it has found to have existed. ${ }^{454}$

The rules that governed the Arbitration are in line with the principles mentioned above in relation to evidence and burden of proof. Article 22 of the Rules of Procedure states, in relevant part, that:

1. Each Party shall have the burden of proving the facts relied on to support its claim or defence.

2. The Arbitral Tribunal may take all appropriate measures in order to establish the facts $[\ldots]$

453 Military and Paramilitary Activities, supra note 71, at para. 101. This principle has been consistently upheld by the I.C.J. See Maritime Delimitation in the Black Sea, supra note 147, at para. 68; Case concerning sovereignty over Pedra Branca/Pulau Batu Puteh, Middle Rocks and South Ledge, supra note 44, at para. 45; Application of the Convention on the Prevention and Punishment of the Crime of Genocide (Bosn. \& Herz. v. Serb. \& Montenegro), 2007 I.C.J. 128, at para. 204 (Feb. 26).

454 Pulp Mills on the River Uruguay, supra note 416, at para. 168. 
4. Pursuant to Article 6 of Annex vil to the Convention, the Arbitral Tribunal may, at any time during the arbitral proceedings, require the Parties to produce documents, exhibits or other evidence within such a period of time as the Arbitral Tribunal shall determine.

Article 6 of Annex VII states that:

The parties to the dispute shall facilitate the work of the arbitral tribunal and, in particular, in accordance with their law and using all means at their disposal, shall:

(a) provide it with all relevant documents, facilities and information; and

(b) enable it when necessary to call witnesses or experts and receive their evidence and to visit the localities to which the case relates.

These rules confirm that the Philippines had the burden of proving its case around, for example, the natural status of features and their capacity to sustain human habitation or economic life of their own. ${ }^{455}$

These fundamental principles are no different in circumstances where one of the parties (here, the respondent party) does not participate in the arbitration. In such circumstances, the claimant party still carries the burden of proving facts relied on to support its claim. At the heart of international dispute resolution is the idea of an adversarial system in which the parties present, investigate, interrogate and argue facts and law. The adversarial system naturally must adapt when one of the parties does not participate in the arbitration. It would make sense therefore that, in such circumstances, e.g., when a respondent party is not present to test the facts and evidence of a claimant party, the tribunal should satisfy itself that it has "jurisdiction" and that the moving party's "claim" is well founded in fact and law. ${ }^{456}$ This is precisely what Article 9 of Annex vil requires:

If one of the parties to the dispute does not appear before the arbitral tribunal or fails to defend its case, the other party may request the tribunal to continue the proceedings and to make its award. Absence of a party or failure of a party to defend its case shall not constitute a bar to the proceedings. Before making its award, the arbitral tribunal must satisfy itself

455 Rules of Procedure, Article 22(1).

$45^{6}$ See Wolfgang Kuhn, Defaulting Parties and Default Awards in International Arbitration, in Contemporary Issues in International Arbitration and Mediation: The Fordham PAPERS 412 (Arthur W. Rovine ed., 2014). 
not only that it has jurisdiction over the dispute but also that the claim is well founded in fact and law. 457

The fact that under Article 9, the Tribunal has an obligation to ensure that "the claim is well founded", does not in any way change the fact that the Philippines carried the burden of proving its claims. In the words of the tribunal in Liberian Eastern Timber Corp. (Lecto) v. Liberia:

[T] he failure of the [... respondent] to take part in the present arbitral proceedings does not entitle the claimant to an award in its favour as a matter of right. The onus is still upon the claimant to establish the claim which it has put forward. 458

In light of these rules of evidence, if the Tribunal determined during the course of the Arbitration that it required further or additional evidence, the Tribunal: (1) "may [...] require the Parties to produce documents, exhibits or other evidence"; (2) may appoint independent experts to assist with the collation of such further or additional evidence; ${ }^{459}$ or (3) "take all appropriate measures in order to establish the facts". ${ }^{460}$ If the Tribunal decides unilaterally to seek out such additional evidence, however, it cannot do so in order to assist the single appearing party satisfy its overriding burden of proof.

Based on these fundamental principles and the related rules applicable to UnCLOS Annex VII arbitration, in our view, if the Tribunal deemed that Philippines had not produced sufficient evidence to prove its case (for example,

457 Similarly, in respect of ITLOS, see Article 28 of Annex VI, "When one of the parties does not appear before the Tribunal or fails to defend its case, the other party may request the Tribunal to continue the proceedings and make its decision. Absence of a party or failure of a party to defend its case shall not constitute a bar to the proceedings. Before making its decision, the Tribunal must satisfy itself not only that it has jurisdiction over the dispute, but also that the claim is well founded in fact and law"; and in respect of the I.C.J., see Article 53 of the Statute of the I.C.J., "Whenever one of the parties does not appear before the Court, $[\ldots][t]$ he Court must [...] satisfy itself, not only that it has jurisdiction [...], but also that the claim is well founded in fact and law". The common dominator is that in cases of default proceedings, the court or tribunal must satisfy itself that the participating party's claim is well founded in fact and law before rendering its decision. See Judith Butchers \& Philip Kimbrough, The Arbitral Tribunal's Role in Default Proceedings, 22(2) Arbitration International 233, 238 (2006).

$45^{8}$ Liberian Eastern Timber Corporation v. Republic of Liberia, ICSID Case No. ARB/83/2, Award, ๆ 25 (Mar. 31, 1986).

459 Rules of Procedure, Article 24.

460 Rules of Procedure, Article 22(2). 
related to the natural status of features or their incapacity to sustain human habitation or economic life of their own), the Tribunal either should have requested that the Philippines produce additional evidence or, alternatively, determined that the Philippines had not met its burden of proof. Instead, as explained below, the Tribunal unilaterally obtained archival evidence (that the Philippines itself deemed "unnecessary") which assisted the Philippines to meet its burden of proof on Submissions No. 4 and 6.

5.2.2 Did the Tribunal Improperly Relieve the Philippines of Its Burden of Proof?

For the purposes of Submissions No. 4 and 6, the Philippines, "[in attempting to overcome the absence of recent, direct observation of the features in question", "placed heavy reliance on remote sensing through satellite imagery".461

The Tribunal did not rely on evidence of satellite imagery that the Philippines provided and, instead, decided to seek out and rely on UKHO and other archival records to determine whether certain maritime features are low-tide elevations. ${ }^{462}$

In a communication to the Parties dated 1 April 2016, the Tribunal explained its rationale for seeking out and relying on evidence that neither Party had produced in the arbitration:

(a) $[\ldots]$ in furtherance of its mandate to satisfy itself that the Philippines' claims are well founded in fact, the Tribunal considered it appropriate to have reference, to the greatest extent possible, to original records based on the direct observation of the features in question, prior to them having been subjected to significant human modification. It informed the Parties that, as the most extensive hydrographic survey work in the South China Sea prior to 1945 was carried out by the Royal Navy of the United Kingdom, followed closely by the Imperial Japanese Navy, the Tribunal had undertaken to seek records from the archives of the United Kingdom Hydrographic Office (the "UKHO"), which also hold certain Japanese records captured during the Second World War. The Tribunal provided documents and survey materials obtained by the Tribunal from the UKHO archives and invited the Parties' comments by 22 April 2016. 463

461 Award, supra note 1, at para. 322.

462 Id. at paras. 89(a), 140.

463 Id. at para. $89(\mathrm{a})$. 
On 28 April 2016, the Philippines submitted its response to the documents and survey materials that the Tribunal obtained from the UKHO. According to the Philippines, the U Kно materials confirmed "the Philippines' characterization of each of the relevant features presented in the Atlas as a submerged feature, a low-tide elevation, or an Article 121(3) "rock"".464

Additionally, by letter of 26 May 2016, the Tribunal informed the Parties that it had decided rely on French Archive Materials from the 1930s "in order to gain a more complete picture as to the natural conditions of the South China Sea features at that time", ${ }^{\prime 65}$ and provided these documents (26 scientific reports, diplomatic records, and newspaper articles $)^{466}$ to the Parties, inviting comments on the same. The documents obtained from the French archives would allow the Tribunal to determine whether Itu Aba and other features in the Spratlys were capable of sustaining human habitation or economic life of its own. ${ }^{467}$

The Philippines filed its response to the French Archive Materials on 3 June 2016, stating that these documents confirmed that:

Itu Aba and other insular features [...] were never inhabited on a permanent or anything resembling a long-term basis, and that they lack the natural resources, including fertile soil and freshwater, necessary to sustain human habitation or economic life [...] and [that] China has not fulfilled the requirements under general international law for establishing [historic] rights. ${ }^{468}$

As mentioned above, by obtaining these archival records, the Tribunal thought that it was furthering "its mandate to satisfy itself that the Philippines' claims are well founded in fact". We agree with the Tribunal's assessment that it had a duty to ensure that the Philippines' "claim is well founded in fact and law". That obligation, important as it may be, has its limits. As explained above, in seeking to ensure that the claims are well founded, the Tribunal must ensure that it does not relieve the moving party of its burden of proof. Although the Tribunal may "take all appropriate measures in order to establish the facts", 469 it may not, sua sponte, seek out evidence that would "establish" the "claim" of the moving party. But, as explained below, that is exactly what the Tribunal

\footnotetext{
464 The Philippines' Written Responses on U кно Materials, 28 April 2016, at para. 3.

465 Award, supra note 1, at para. 99.

466 The Philippines' Written Responses on French Archive Materials, 3 June 2016, at para. 1.

467 Award, supra note 1, at paras. 99, 141.

468 The Philippines' Written Responses, supra note 466, at para. 2.

469 Rules of Procedure, Article 22(2).
} 
did here - it obtained evidence (that had been rejected by the Philippines) to establish the Philippines' claims.

The Philippines carried the obligation to prove its claims through documentary and other evidence. Prior to the Merits Hearing, the Tribunal requested that the Philippines confirm "whether it has sought and been able to obtain copies of hydrographic survey plans (fair charts), relating in particular to those surveys undertaken by the United Kingdom in the Nineteenth Century...." ${ }^{\prime 40}$ The Philippines replied that "it has not and explained that it considered it unnecessary to do so".471

This Philippines' response demonstrates that it made a strategic decision not to produce archival materials to support its claims. Moreover, the Philippines refused to produce such evidence even after being prompted by the Tribunal to do so. This was sufficient basis for the Tribunal to conclude that the Philippines' claims, which "placed heavy reliance on remote sensing through satellite imagery", was not well-founded in fact. In our view, the Tribunal erred by, sua sponte, finding additional facts and evidence (that the Philippines itself deemed "unnecessary") that, in the Tribunal's view was required prove the Philippines claims.

5.2.3 The Tribunal's Conclusion that China Failed to Have Due Regard to the Rights and Duties of the Philippines in the Vicinity of Mischief Reef

In its Submission no. 9, the Philippines requested that the Tribunal declare that "China has unlawfully failed to prevent its nationals and vessels from exploiting the living resources in the exclusive economic zone of the Philippines". 472

This submission related to "developments at Mischief Reef and Second Thomas Shoal, both of which are low-tide elevations lying within 200 nautical miles of the Philippines' baselines." ${ }^{\text {"73 }}$

The Tribunal found that:

Mischief Reef and Second Thomas Shoal are not capable of generating entitlements to maritime zones and can only form part of the Philippines' exclusive economic zone. Nevertheless, in light of the fact that China has not accepted these areas as part of the Philippines' exclusive economic zone, the Tribunal considers the similarities in Chinese fishing activities

470 Award, supra note 1, at para. 140.

$471 \quad I d$.

472 Id. at para. 717.

473 Id. at para. 718. 
at all of these features to be a significant indication of what has taken place at Mischief Reef and Second Thomas Shoal.

$[\ldots]$

The Tribunal expects, from the general positions of the Parties, that Chinese vessels have continued to fish at Mischief Reef and Second Thomas Shoal since May 2013. The Tribunal does not, however, have the direct evidence before it that would enable it to draw such a conclusion for the period subsequent to May 2013.

$[\ldots]$

Having established that Chinese vessels have been engaged in fishing at Mischief Reef and Second Thomas Shoal in May 2013, the Tribunal considers that China has failed to show the due regard called for by Article 58(3) of the Convention to the Philippines' sovereign rights with respect to fisheries within its exclusive economic zone. ${ }^{474}$

The Tribunal recognised that it had "limited evidence before it" with respect to Chinese fishing at Mischief Reef. ${ }^{475}$ It appears that the only evidence of Chinese fishing at Mischief Reef came from a Filipino source, i.e., the Philippines Armed Forces, which had reported that at least 33 Chinese fishing vessels were said to have been fishing at the Chinese-occupied Mischief Reef and nearby features since 08 May 2013, escorted by a PLA Navy ship and CMS vessels. The report of the Armed Forces does not mention the source of this information i.e., the identity of the person who provided this information.

The Philippines initiated arbitration against China on 22 January 2013. The observations contained in this report are of alleged fishing activities in May 2013 i.e., after the "dispute" had crystallised and after the Philippines had initiated arbitration against China. This raises serious doubts about the reliability of such (hearsay) evidence, which could not be tested under cross-examination (or otherwise tested by the Tribunal).

The Tribunal provided two reasons for accepting the Filipino evidence of Chinese fishing at Mischief Reef in May 2013: (1) the fact that "China has asserted sovereign rights and jurisdiction in the South China Sea generally, and has apparently not accepted these areas as part of the Philippines' exclusive economic zone [...]"; and (2) "the pattern of Chinese fishing activity at Mischief Reef and Second Shoal is consistent with that exhibited at other reef formations for which the Tribunal has information". ${ }^{476}$ Both reasons appear

474 Id at paras. $75^{-}-53$.

475 Id at para. 745 .

476 Id. at paras. $747-48$. 
to reference inadequate "evidence" of Chinese fishing at Mischief Reef. The fact that China asserts the right to fish does not mean that Chinese vessels have conducted such fishing activities. The fact that there may be evidence of Chinese fishing in other parts of the South China Sea is, again, not proof of Chinese fishing at Mischief Reef.

Arguably, the Philippines did not meet its burden of proof with respect to its claim that China had failed to show due regard for the Philippines' sovereign rights with respect to fishing in the vicinity of Mischief Reef.

\subsection{The Tribunal Denied the Parties Sufficient Opportunity to Examine Its Appointed Experts}

Clearly, the evidence of technical experts was likely to be probative given a number of the issues raised by the Philippines in the South China Sea arbitration. Even during the jurisdictional phase, the Tribunal invited the Parties to "take steps already to ascertain the availability of potential technical experts". 47 Separately, the Tribunal appointed its own experts in the arbitration. For example, on 7 August 2015, the Tribunal proposed Mr Grant Boyes as its expert hydrographer, who was subsequently appointed after the Tribunal invited the Parties to comment on his curriculum vitae, declaration of independence and Terms of Reference. ${ }^{478}$ There was nothing objectionable with the Tribunal's appointment of Mr Boyes, and the appointment by international courts and tribunals of expert hydrographers is commonplace in law of the sea disputes. Specifically, the appointment appears to have been made in accordance with Article 24 of the Rules of Procedure, which states in relevant part that:

1. After seeking the views of the Parties, the Arbitral Tribunal may appoint one or more independent experts. [...]

2. Any expert shall, in principle before accepting appointment, submit to the Arbitral Tribunal and to the Parties a description of his or her qualifications and a statement of his or her impartiality and independence. [...]

4. If called upon to prepare an expert's report, the Arbitral Tribunal shall, upon receipt of the report, communicate a copy of it to the Parties, who shall be given the opportunity to express, in writing, their respective opinions on the report. A Party shall be entitled to examine any document on which the expert relied in his or her report.

5. If a Party so requests or if the Arbitral Tribunal considers it necessary, the expert shall, after delivery of the report, participate in a hearing where

$477 \quad I d$. at para. 56 .

$47^{8}$ Id. at para. $5^{8}$. 
the Parties have the opportunity to put questions to him or her and to present expert witnesses in order to testify on the points at issue. The provisions of Article 23 shall be applicable to such proceedings.

Following the November 2015 Merits Hearing, on 5 February 2016, the Tribunal considered it necessary to obtain "further evidence and clarifications from the Parties, and from the views of independent experts". 479 At that stage, the Tribunal decided to appoint additional experts to opine on: (1) whether Chinese construction activities in the Spratly Islands have a detrimental effect on the coral reef systems; and (2) navigational safety issues.

The Tribunal sought the views of the Parties and, around mid-March 2016, proceeded to appoint Dr Sebastian Ferse and Captain Gurpreet Singh Singhota, to provide expert opinions on these issues. ${ }^{480}$ On 12 April 2016, the Tribunal decided to appoint two additional coral reef experts, Professor Peter Mumby and Dr Selina Ward, to contribute to the expert opinion that at the time was being prepared by Dr Ferse. ${ }^{481}$

The four new Tribunal-appointed experts issued their expert reports on 15 April and 26 April 2016 (i.e., only three months before the Tribunal rendered its 500-page Merits Award). ${ }^{482}$ The Tribunal provided the reports to the Parties and, in accordance with the Rules of Procedure, invited comments in writing on 18 and 29 April 2016, respectively. ${ }^{483}$ It is not clear from the public record whether, in accordance with Article 24(4), the Tribunal provided the Parties with an opportunity to "examine any document on which the expert relied in his or her report".

These tribunal-appointed experts were not cross-examined by the Parties. Strictly, the Rules of Procedure did not require that tribunal-appointed experts be cross-examined on their reports - as mentioned above, they provided only that if "a Party so requests or if the Arbitral Tribunal considers it necessary, the expert shall, after delivery of the report, participate in a hearing where the Parties have the opportunity to put questions to him or her and to present expert witnesses in order to testify on the points at issue." It appears that the Parties were effectively denied the opportunity to cross-examine these experts due to the experts' very late appointment by the Tribunal in the proceeding (after the Merits hearing), the fact that the Tribunal only invited comments

\footnotetext{
479 Id. at para. 84.

48 o Id. at paras. $84-85$.

481 Id. at para. 90.

482 Id. at paras. 91,95 .

483 Id.
} 
in writing and did not contemplate the possibility of any hearing to examine their evidence prior to issuing its Merits Award.

The failure to provide any opportunity to the Parties to cross-examine the four experts is particularly notable given the findings subsequently made in the Merits Award with reference to their evidence. For example, the Tribunal relied on Dr Ferse's conclusion that the Chinese navy and coast guard had "tolerated or condoned" the practice of "chopping reefs" by Tanmen fishermen and his views on the impact of construction and dredging activities on reef systems. ${ }^{484}$ It also relied on Captain Singhota's evidence that "Chinese manoeuvres [...] 'demonstrated a complete disregard for the observance and practice of good seamanship [...] but most importantly, a total disregard for the observance of the collision regulations. ${ }^{485}$ Given that the Tribunal extensively relied on the evidence of these experts, in our view, the Parties should have been afforded an opportunity to cross-examine these experts on their evidence.

\subsection{The Tribunal Misapplied the Monetary Gold Principle with Respect to Third State Rights and Interests}

Disputes in the Spratly Islands involve both islands and maritime claims among several sovereign states within the region, namely Brunei, China (including Taiwan), Malaysia, the Philippines, and Vietnam. These states all laid claims and occupied part of the islands in the South China Sea.

This Section will analyse whether the Tribunal should have accepted jurisdiction over determining the legal classification (and thus maritime entitlements) of maritime features in the South China Sea (including but not limited to Itu Aba) that are the subject of sovereignty and maritime claims by third States (in particular, Brunei, Malaysia, and Vietnam). We have focussed on the claims (or potential claims) of Malaysia, Vietnam and Taiwan with respect to those features and the potential application of the ICJ's judgment in the Monetary Gold case.

Sub-section (i) explains the scope of the principle espoused in Monetary Gold, which has been clarified and developed through the jurisprudence of international courts and tribunals; Sub-section (ii) explains that there are other important principles of international law that suggest that the Tribunal should have adopted a more cautious approach to the exercise of jurisdiction when third party rights are at issue; Sub-section (iii) analyses whether the

484 Id. at paras. $848,851,857,978,983$.

485 Id. at para. 1089 . 
Tribunal determined correctly that the "legal interests of Malaysia do not form 'the very subject-matter of the dispute' and are not implicated by the Tribunal's conclusions"; and Sub-section (iv) analyses whether Vietnam's and Taiwan's legal interests in the South China Sea form "the very subject-matter of the dispute" that was the subject of the Merits Award.

$5 \cdot 4.1$

The Scope of the Principle Espoused in Monetary Gold with Respect to Third Party Rights

The Tribunal explained in the Merits Award the scope of the Monetary Gold principle. The Tribunal stated that:

[r]ead correctly, Monetary Gold calls for a court or tribunal to refrain from exercising its jurisdiction where the legal interests [of a third State] would not only be affected by a decision, but would form the very subjectmatter of the decision'. The circumstances of Monetary Gold, however, 'represent the limit of the power of the Court to refuse to exercise its jurisdiction,' and any more expansive reading would impermissibly constrain the practical ability of courts and tribunals to carry out their function. ${ }^{486}$

The Tribunal's exposition of the Monetary Gold principle is correct as a matter of international law. The Monetary Gold case arose out of the discovery in Germany of certain quantities of monetary gold belonging to Albania. The governments of France, the UK and the US were tasked with responsibility for implementing a 1946 Agreement on Reparation which required that monetary gold found in Germany should be pooled for distribution among the countries entitled to receive it. The UK claimed that the Albanian gold should be delivered to the UK in partial satisfaction of the Court's Judgment of 1949 against Albania in the Corfu Channel case. Italy claimed that the gold should be delivered to it in partial satisfaction for the damage which it alleged it had suffered as a result of an Albanian law of 13 January 1945. The three countries tasked with implementing the agreement decided that that the gold should be delivered to the United Kingdom unless, within a certain time-limit, Italy or Albania applied to the Court requesting it to adjudicate on their respective rights. Albania took no action, but Italy made an application to the Court. The Court observed:

486 Id. at para. 640. 
The Court is not merely called upon to say whether the gold should be delivered to Italy or to the United Kingdom. It is requested to determine first certain legal questions upon the solution of which depends the delivery of the gold.<smiles>[CH]1CNC1</smiles>

Albania has not submitted a request to the Court to be permitted to intervene. In the present case, Albania's legal interests would not only be affected by a decision, but would form the very subject-matter of the decision. In such a case, the Statute cannot be regarded, by implication, as authorizing proceedings to be continued in the absence of Albania. 487

As Albania was not present before the Court, and given that its "legal interests [...] would form the very subject matter of the decision", the Court declined jurisdiction over Italy's application.

The Court subsequently adopted the Monetary Gold principle in the East Timor case, again to decline jurisdiction, this time due to the absence of Indonesia. ${ }^{488}$ Overall, however, the ICJ jurisprudence demonstrates that a relatively high threshold is applied in order for the Monetary Gold standard to preclude jurisdiction.

The ICJ discussed the scope of the Monetary Gold principle in the Military and Paramilitary Activities in and against Nicaragua case (Nicaragua v. United States). Nicaragua claimed that the US had supported rebels in Nicaragua, Costa Rica and Honduras and had provided logistical support and weapons to the guerrilla forces in El Salvador who were fighting against Nicaragua's interests. ${ }^{489}$

The US claimed that Nicaragua's application to the Court was inadmissible, in part, because third States not present before the Court, including Honduras

487 Case of the Monetary Gold Removed from Rome in 1943 (It. v. Fr., U.K. \& U.S.), 1954 I.C.J. Rep. 19 (June 15) (Judgment) at 32-33.

488 The Court determined in that case that: “... Australia's behaviour cannot be assessed without first entering into the question why it is that Indonesia could not lawfully have concluded the 1989 Treaty, while Portugal allegedly could have done so [...] the very subject-matter of the Court's decision would necessarily be a determination whether, having regard to the circumstances in which Indonesia entered and remained in East Timor, it could or could not have acquired the power to enter into treaties on behalf of East Timor relating to the resources of its continental shelf. The Court could not make such a determination in the absence of the consent of Indonesia." See East Timor (Port. v. Austl.), 1995 I.C.J. Rep. 91 (June 30) (Judgment), at para. 28.

489 Military and Paramilitary Activities, supra note 71, at paras. 18-25. 
and El Salvador, had an interest in the dispute but were not present before the Court. 490

The Court rejected this argument, emphasising that its decision had a binding effect for the parties only and that third States that may be affected by the decision could either institute separate proceedings or apply for permission to intervene in the present proceedings. ${ }^{491}$ The Court confirmed (as stated also in the Merits Award) that the Monetary Gold principle would preclude jurisdiction only when third part rights form the "very subject matter of the decision". The Court's explanation merits quotation in full:

There is no doubt that in appropriate circumstances the Court will decline, as it did in the case concerning Monetary Gold Removed from Rome in 1943, to exercise the jurisdiction conferred upon it where the legal interests of a State not party to the proceedings "would not only be affected by a decision, but would form the very subject-matter of the decision" (ICJ Reports 1954, p. 32). Where however claims of a legal nature are made by an Applicant against a Respondent in proceedings before the Court, and made the subject of submissions, the Court has in principle merely to decide upon those submissions, with binding force for the parties only, and no other State, in accordance with Article 59 of the Statute. As the Court has already indicated (paragraph 74, above) other States which consider that they may be affected are free to institute separate proceedings, or to employ the procedure of intervention. There is no trace, either in the Statute or in the practice of international tribunals, of an 'indispensable parties' rule of the kind argued for by the United States, which would only be conceivable in parallel to a power, which the Court does not possess, to direct that a third State be made a party to proceedings. The circumstances of the Monetary Gold case probably represent the limit of the power of the Court to refuse to exercise its jurisdiction; and none of the States referred to [by the USA] can be regarded as in the same position as Albania in that case, so as to be truly indispensable to the pursuance of the proceedings. ${ }^{492}$

490 Id. at paras. $437-43$.

491 Id. at para. 88.

492 Id. See also Land, Island and Maritime Frontier Dispute, supra note 40, at para. 56. The I.C.J. examined whether the legal interests asserted by Nicaragua in support of an application to intervene in the case formed "the very subject matter of the decision" or whether Nicaragua was only affected by that decision. 
The Monetary Gold principle also arose in the Case concerning certain phosphate lands in Nauru (Nauruv. Australia), in respect of a dispute over the rehabilitation of lands in Nauru that previously had been under Australian administration. According to Nauru's submission before the ICJ, Australia had breached its international obligations, including obligations under the Trusteeship Agreement for Nauru. ${ }^{493}$

One of Australia's preliminary objections, focussed on the fact that third States i.e., New Zealand and the United Kingdom (which, together with Australia, formed the Administering Authority for Nauru under the Trusteeship Agreement) were not parties to the ICJ proceeding. ${ }^{494}$

The Court considered Australia's objection in light of the Monetary Gold principle and determined that:

In the present case, the interests of New Zealand and the United Kingdom do not constitute the very subject-matter of the judgment to be rendered on the merits of Nauru's Application and the situation is in that respect different from that with which the Court had to deal in the Monetary Gold case. In the latter case, the determination of Albania's responsibility was a prerequisite for a decision to be taken on Italy's claims. In the present case, the determination of the responsibility of New Zealand or the United Kingdom is not a prerequisite for the determination of the responsibility of Australia, the only object of Nauru's claim. [...]

a finding by the Court regarding the existence or the content of the responsibility attributed to Australia by Nauru might well have implications for the legal situation of the two other States concerned, but no finding in respect of that legal situation will be needed as a basis for the Court's decision on Nauru's claims against Australia. ${ }^{495}$

The Court therefore focussed on whether it would be required to determine the "responsibility" of a third party as "a prerequisite for a decision to be taken on" the claims before the Court, or whether it would be required to make a finding in respect of the "legal situation" of the third parties. Sub-section (ii) and (iii) below assesses whether the Tribunal necessarily had to make determinations about the "responsibility" of Malaysia, Vietnam and Taiwan, or in

493 Certain Phosphate Lands in Nauru (Nauru v. Austl.), 1992 I.C.J. Rep. 240 (June 26) (Judgment on Preliminary Objections), at para. 5 .

494 Id. at para. 39.

495 Id. at para. 55 . 
respect of the "legal situation" of those States, in order to determine the merits of the claims submitted by the Philippines.

The principle of due process (from which the Monetary Gold principle "draws its strengths") also suggests that tribunals should exercise caution when third-party rights are at issue. For example, in Chevronv. Ecuador (Third Interim Award on Jurisdiction and Admissibility), the tribunal explained that:

... the Monetary Gold principle draws its strengths from, and implements, a number of distinct and fundamental principles of international law. Most obviously, it gives effect to the principle that no international tribunal may exercise jurisdiction over a State without the consent of that State; and by analogy, no arbitration tribunal has jurisdiction over any person unless they have consented. That may be called the 'consent' principle, and it goes to the question of the tribunal's jurisdiction.

In the Monetary Gold case itself, the International Court of Justice held that, as a corollary of the 'consent' principle, if the very subjectmatter of the case that it has to decide is a question of the rights of a State not before it, the International Court cannot proceed to decide the case. In such a case, the Court would not hear full argument on the rights in question. That corollary may be called the 'indispensible [sic.] third party' principle; and it goes to the question of the ability of the tribunal to decide the case justly and according to law.

There is also a concern that the rights of States should not be ruled upon unless they are properly before the Court and are given a full opportunity to present their case. This third aspect may be called the "due process" principle; and it goes to the question of the rights of the absent third party. ${ }^{496}$

This quote from Chevron suggests that there are broader concerns, especially around the due process rights of third parties, that should be borne in mind by international courts and tribunals when exercising jurisdiction over a dispute that concerns third party rights. As discussed below, it appears to us that the Tribunal applied the Monetary Gold principle (only with reference to Malaysia) without consideration of these broader due process principles.

496 Chevron Corporation and Texaco Petroleum Corporation v. The Republic of Ecuador, UNCITRAL, PCA Case No. 2009-23, Third Interim Award on Jurisdiction and Admissibility, at paras. $4.61-63$. 
5.4.2 The Tribunal's Conclusion that the "Legal Interests of Malaysia Do Not Form 'the Very Subject-Matter of the Dispute' and are Not Implicated by the Tribunal's Conclusions"

The Merits Award refers to a communication from Malaysia to the Tribunal, dated 23 June 2016, in which:

Malaysia recalls that it claims sovereignty over a number of features in the South China Sea and 'may also have overlapping maritime entitlements (including an extended continental shelf) in the area of some of the relevant features that the Arbitral Tribunal has been asked to classify. ${ }^{497}$

Malaysia's communication is not publicly-available. According to the Tribunal, in its communication, Malaysia invokes the Monetary Gold principle and "argues" that:

The Arbitral Tribunal must ensure that, in determining whether certain maritime features in the South China Sea are entitled to specific maritime zones under UNCLOS 1982, it does not express any position that might directly or indirectly affect the rights and interests of Malaysia. The Arbitral Tribunal thus cannot purport to decide upon the maritime entitlements pursuant to Articles 13 and 121 of UNCLOS 1982 of any features within the EEZ and Continental Shelf of Malaysia as published in Malaysia's Map of $1979 .^{498}$

The Tribunal concluded that "to the extent it has examined certain features claimed by China (which are also claimed by Malaysia) for the purposes of assessing the possible entitlements of China in areas to which Malaysia makes no claim, the legal interests of Malaysia do not form 'the very subject-matter of the dispute' and are not implicated by the Tribunal's conclusions." 499 Consequently, in the Tribunal's view, Malaysia's rights and interests were protected, and did not engage the rule in Monetary Gold. ${ }^{500}$

The Tribunal was probably correct in concluding that Malaysia's communication "overstates the Monetary Gold principle when it argues expansively that the Tribunal must "avoid deciding any question that requires it to adopt a

\footnotetext{
497 Award, supra note 1, at para. 635 .

498 Id.

499 Id. at para. 640.

$500 \quad I d$. at paras. $640-41$.
} 
view that, directly or indirectly, may affect Malaysia's rights and interests"'."501 As explained above, in order to demonstrate that the Tribunal's award on the merits would violate the Monetary Gold principle, Malaysia would need to have demonstrated that its legal interests formed the very subject-matter of the dispute before the Tribunal.

Although the extract of Malaysia's communication set out in the Award does not accurately reflect the test under Monetary Gold, in our view, the Tribunal did not investigate adequately whether Malaysia's claims in the South China Sea form the "very subject matter" of the Tribunal's decision with respect to the classification of certain features in the Spratlys. The Tribunal found that:

[w]ith respect to the Philippines' Submission No. 5, the Tribunal notes that Mischief Reef and Second Thomas Shoal do lie within 200 nautical miles of features claimed by Malaysia, although Malaysia itself has not claimed an exclusive economic zone or continental shelf in the area of either Mischief Reef or Second Thomas Shoal. ${ }^{502}$

It appears that the Tribunal did not consider that Malaysia's interests in the South China Sea relate not only to Mischief Reef and Second Thomas Shoal but also to a number of additional features. We understand from publicly-available materials that Malaysia claims sovereignty over 11 features in the Spratly Islands. ${ }^{503}$ These are: (1) Ardasier Reef; (2) Dallas Reef; (3) Mariveles Reef; (4) Royal Charlotte Reef; (5) Swallow Reef; (6) Erica Reef; (7) Investigator Reef; (8) Commodore Reef; (9) Amboyna Cay; (10) Barque Canada Reef; and (11) North Luconia and South Luconia Shoals.504

The Tribunal determined that Swallow Reef and Amboyna Cay are "rocks" for the purposes of Article 121(3) of the Convention, with the result that they are incapable of generating any EEZ or continental shelf entitlement. This was an essential prerequisite to the Tribunal's jurisdiction over the Philippines' Submission nos. 5 and 7 .

It is possible that Malaysia may claim to derive EEz or continental shelf rights from any one or more of the above-mentioned 11 features in the Spratlys.

\footnotetext{
501 Id. at para. 640 .

$5 \mathrm{O} 2 \mathrm{Id}$. at para. 629 .

503 See, J. Ashely Roach, Malaysia and Brunei: An analysis of their Claims in the South China Sea, https://www.cna.org/cna_files/pdf/IOP-2014-U-oo8434.pdf.

504 Id.
} 
The Tribunal's decision that Swallow Reef and Amboyna Cay (and, indeed, that all high tide features in the Spratly Islands) are "rocks", 505 clearly would prejudice any such claims.

\subsubsection{Do Vietnam's Legal Interests Form “the Very Subject-Matter of the Dispute"?}

The Merits Award does not discuss whether Vietnam's claims in the South China Sea form the very subject matter of certain of the claims submitted by the Philippines. In our view, the Tribunal should have assessed proprio motu ${ }^{506}$ whether its exercise of jurisdiction might violate the Monetary Gold principle with respect to Vietnam's putative legal interests in the South China Sea. ${ }^{507}$

\subsubsection{Vietnam's Position with Respect to the Spratlys}

On 12 May 1977 (i.e., before UNCLOS), Vietnam published its Declaration on the Territorial Sea, the Contiguous Zone, the Exclusive Economic Zone and the Continental Shelf, which states, in relevant part, that:

505 Award, supra note 1, at para. 646.

506 For example, in the investor-State dispute resolution context, tribunals have found that they are must consider questions of jurisdiction proprio motu in some situations. See, e.g., Mihaly International Corporation v. Democratic Socialist Republic of Sri Lanka, ICSID Case No. ARB/oo/2, Award of 15 March 2002, at para. 56: "The Tribunal further observes that the question of jurisdiction of an international instance involving consent of a sovereign State deserves a special attention at the outset of any proceeding against a State Party to an international convention creating the jurisdiction. As a preliminary matter, the question of the existence of jurisdiction based on consent must be examined proprio motu, i.e., without objection being raised by the Party." The obligation is also established in I.C.J. jurisprudence. See Aegean Sea Continental Shelf (Greece v. Turk.), 1977 I.C.J. Rep. 3 (Dec. 19) (Judgment), at para. 15:"the Court, in accordance with its Statute and its settled jurisprudence, must examine proprio motu the question of its own jurisdiction to consider the Application of the Greek Government. Furthermore, in the present case the duty of the Court to make this examination on its own initiative is reinforced by the terms of Article 53 of the Statute of the Court. According to this provision, whenever one of the parties does not appear before the Court, or fails to defend its case, the Court, before finding upon the merits, must satisfy itself that it has jurisdiction." See also United States Diplomatic and Consular Staff in Tehran (U.S. v. Iran), 1980 I.C.J. Rep. 3 (May 24) (Judgment), at para. 33: "Nevertheless, in accordance with its settled jurisprudence, the Court, in applying Article 53 of its Statute, must first take up, proprio motu, any preliminary question, whether of admissibility or of jurisdiction, that appears from the information before it to arise in the case and the decision of which might constitute a bar to any further examination of the merits of the Applicant's case."

507 The Tribunal's Merits Award may also affect the rights and obligations of other States with interests in the South China Sea, including those of Brunei and Indonesia. 
1. The territorial sea of the Socialist Republic of Vietnam has a breadth of 12 nautical miles measured from a baseline which links the furthest seaward points of the coast and the outermost points of Vietnamese offshore islands, and which is the low-waterline along the coast.<smiles>[CH]1CNC1</smiles>

5. The islands and archipelagos, forming an integral part of the Vietnamese territory and beyond the Vietnamese territorial sea mentioned in Paragraph 1, have their own territorial seas, contiguous zones, exclusive economic zones and continental shelves, determined in accordance with the provisions of Paragraphs 1, 2, 3, and 4 of this statement. 508

Five years later, on 12 November 1982, Vietnam issued its Statement on the Territorial Sea Baseline, which states at paragraphs 4 and 5 :

(4) The baseline for measuring the breadth of the territorial sea of the Hoang Sa [Paracel Islands] and Truong Sa [Spratly Islands] Archipelagos will be determined in a coming instrument in conformity with paragraph 5 of the 12 May 1977 statement of the Government of the Socialist Republic of Viet Nam. [...]

(5) The sea as lying behind the baseline and facing the coast or the islands of Viet Nam constitutes the internal waters of the Socialist Republic of Viet Nam. ${ }^{509}$

This shows that, by the early 1980s, Vietnam had indicated on multiple occasions that it would claim maritime zones, including EEZ and continental shelf entitlements, from the Spratly "archipelago". 510

In a statement dated 5 December 2014, however, Vietnam informed the Tribunal that, in its view:

508 Available in English on the website of the United States Department of State, https:// www.state.gov/documents/organization/58573.pdf, last visited 30 August 2018.

$5 \circ 9$ http://www.un.org/depts/los/LEGISLATIONANDTREATIES/PDFFILES/VNM_1982_ Statement.pdf, last visited 30 August 2018.

510 Note that, on 6 May 2009, Malaysia and Vietnam made a joint submission to the CLCS for a portion of the continental shelf of the two States into the South China Sea. The area of the extended continental shelf is drawn between the $200 \mathrm{~nm}$ limits of the two States measured from the baselines along the coasts of Vietnam and the East Malaysian states of Sarawak and Sabah. This would suggest that Vietnam does not (as yet) claim a continental shelf from its Spratly archipelago. 
none of the maritime features mentioned by the Philippines in these proceedings can enjoy their own exclusive economic zone and continental shelf or generate maritime entitlements in excess of 12 nautical miles since they are low-tide elevations or 'rocks which cannot sustain human habitation or economic life of their own' under Article 121(3) of the Convention. 511

Vietnam's 2014 statement to the Tribunal must be read against the backdrop of its previous position that the Spratlys form an "archipelago", over which Vietnam claims sovereignty. Vietnam reiterated this position in two of the annexes to its the Statement to the Tribunal. Its annex 1, which contains a Note Verbale dated 8 May 2009 from the Permanent Mission of Vietnam at the UN to the UN Secretary General, states that:

The Hoang Sa (Paracels) and Truong Sa (Spratlys) archipelagos are parts of Viet Nam's territory. Viet Nam has indisputable sovereignty over these archipelagoes. China's claim over the islands and adjacent waters in the Eastern Sea (South China Sea) as manifested in the map attached with the Notes Verbales CLM/17 /2009 and CLM/18/2009 has no legal, historical or factual basis, therefore is null and void. ${ }^{512}$

Moreover, Annex 6, which contains a letter, dated 19 November 2014, from the Permanent Representative of Vietnam to the United Nations Secretary General, ${ }^{513}$ implicitly confirms that Vietnam claims that the Spratly "archipelago" generates maritime entitlements, including with respect to the EEZ and the continental shelf:

Viet Nam possesses full legal basis and historical evidence to affirm its sovereignty over the Hoang Sa (Paracels) and Truong Sa (Spratlys) archipelagos, as well as its sovereign rights and jurisdiction over the exclusive

511 Award, supra note 1, at para. 36. Statement of the Ministry of Foreign Affairs of the Socialist Republic of Viet Nam Transmitted to the Arbitral Tribunal in the Proceedings between the Republic of the Philippines and the People's Republic of China', 5 December 2014.

512 Note Verbale from the Permanent Mission of the Socialist Republic of Vietnam to the United Nations to the Secretary-General of the United Nations, No. 86/HC-2oo9 (8 May 2009), Annex 193.

513 Annex to the letter dated 19 November 2014 of the Permanent Representative of the Socialist Republic of Viet Nam addressed to the Secretary-General of the United Nations,' in Supplemental Written Submission of the Philippines, Volume III, Annexes 466-99, 16 March 2015, at 65-67. 
economic zone and the continental shelf established in accordance with [UNCLOS].514

Although Vietnam officially has not drawn Eezs from the Spratly or Paracel "archipelagos", the above statements indicate that it has been Vietnam's position that the Paracel and Spratly Island groups are "archipelagos" that generate maritime entitlements beyond $12 \mathrm{~nm}$, even if the individual features within those archipelagos do not generate such entitlements.

\subsubsection{How Did Vietnam Respond to the Arbitration?}

Although it appears that Vietnam was generally supportive of the Tribunal taking jurisdiction, on 14 December 2014 Vietnam wrote to the Tribunal informing it that:

After reading the written pleadings of the Philippines, the Ministry of Foreign Affairs of Viet Nam is of the view that some of Viet Nam's rights and interests of a legal nature in the South China Sea may be involved, and even affected in this arbitration. By transmitting the present Statement to the Arbitral Tribunal, the Ministry of Foreign Affairs of Viet Nam wishes to preserve its rights and interests of a legal nature, including (but not necessarily limited to):

(i) Viet Nam's rights in connection with geographical features of the Paracel Islands (quần đảo Hoàng Sa in Vietnamese) and the Spratly Islands (quần đảo Trường Sa in Vietnamese);

(ii) The rights and interests of Viet Nam in its exclusive economic zone and continental shelf;

(iii) The rights and interests of Viet Nam relating to the legal status and maritime entitlement of geographical features in the South China Sea, which are located within the 'nine-dash line';

(iv) The rights and interests of Viet Nam in common maritime areas located within the "nine-dash line"; and

(v) The other legal rights and interests of Viet Nam in the South China Sea. ${ }^{515}$

514 Annex to the letter dated 19 November 2014 from the Permanent Representative of Viet Nam addressed to the Secretary-General of the United Nations, Annex 468; see also, Note Verbale No. 771/HC-98 dated 6 August 1998 of the Permanent Mission of the Socialist Republic of Viet Nam to the United Nations addressed to the United Nations Secretary-General, Annex 468.

515 Statement of the Ministry of Foreign Affairs of the Socialist Republic of Viet Nam transmitted to the Arbitral Tribunal in the Proceedings between The Republic of the Philippines and The People's Republic of China, 14 December 2014, Annex 468, 44. 
As discussed above, the mere risk that third-party interests may be "affected" by the Tribunal's Award is not sufficient to preclude jurisdiction. In order to rely on the Monetary Gold principle, Vietnam would have needed to show that its legal interests in the South China Sea formed the "very subject matter" of the claims submitted to the Tribunal. Although Vietnam explicitly did not request that the Tribunal apply the Monetary Gold principle, in our view, the Tribunal should have proprio motu assessed whether any of the claims before it went to the very subject matter of Vietnam's claims in the South China Sea.

\subsubsection{The Tribunal's Conclusions with Respect to Vietnam}

The Tribunal in its Award on Jurisdiction applied the Monetary Gold principle with respect to Vietnam. The Tribunal concluded that:

the determination of the nature of and entitlements generated by the maritime features in the South China Sea does not require a decision on issues of territorial sovereignty. The legal rights and obligations of Viet Nam therefore do not need to be determined as a prerequisite to the determination of the merits of the case. ${ }^{516}$

In its Merits Award the Tribunal referred to its earlier finding in the jurisdictional phase that "the legal rights and obligations of Viet Nam do not need to be determined as a prerequisite to the determination of the merits of the case" 517

In our view, the Tribunal's decision that Vietnam's claims in the South China Sea do not form the "very subject matter of the decision" is arguably wrong. On this basis, the Tribunal arguably erred in accepting jurisdiction over a number of the Philippines' Submissions.

In its Merits Award, the Tribunal clearly made determinations with respect to the "legal status and maritime entitlement of geographical features in the South China Sea", in respect of which Vietnam had explicitly stated that it enjoys "rights and interests". The Tribunal also rejected the notion that "the Spratly Islands should be enclosed within a system of archipelagic or straight baselines, surrounding the high-tide features of the group, and accorded an entitlement to maritime zones as a single unit". 518

In reaching these findings, the Tribunal arguably made findings with respect to the "legal situation" of Vietnam. In the words of the Tribunal (with respect to

$5^{16}$ Award on Jurisdiction and Admissibility, supra note 2, at para. 180.

517 Award, supra note 1, at para. 157.

518 Id. at para. 573 . 
the application of the Monetary Gold principle to Malaysia), the legal interests of Vietnam were clearly "implicated" by its findings with respect to the legal classification (whether as "rocks", low-tide elevations or otherwise) of certain features claimed by Vietnam. In this sense, the Award clearly prejudice the "rights and interests of a legal nature" cited by the Vietnamese Foreign Ministries in its letter to the Tribunal dated 22 January 2013. ${ }^{519}$

Vietnam's legal interests were further "implicated" by the Tribunal's apparent dismissal of any notion that the Spratlys could generate archipelagic entitlements at international law. Although Vietnam officially has not drawn any straight baselines around the Spratly Islands, as described above there are indications that Vietnam claims rights and interests based upon its assessment that the Spratly Islands form an "archipelago". The Tribunal's decision that China cannot enjoy any maritime entitlements or "historic rights" based upon the Spratlys as an archipelago appears to prejudice such Vietnamese claims.

For these reasons, there is a credible argument that the Merits Award violates the Monetary Gold principle at least with respect to Vietnam's claims in the South China Sea.

\subsubsection{Taiwan's Concern on TaiPing Dao (Itu Aba) \\ 5.4.4.1 Taiwan Authority of China (Hereafter Referred to as Taiwan)'s Position}

Taiwan claims that Itu Aba is a fully-entitled island the purposes of Article 121(1) of UNCLOS. Moreover, it explicitly does so with reference to UNCLOS. Taiwan's position is that:

Taiping Island (Itu Aba, the largest ( 0.43 square $\mathrm{km}$ ) of the naturally formed Nansha (Spratly) Islands, has been garrisoned by Roc troops since 1956. [...] For the past six decades, Roc military and civilian personnel have dwelled on Taiping Island (Itu Aba), conducting their respective missions while making use of and developing its natural resources. Taiping Island (Itu Aba) has groundwater wells, natural vegetation, and phosphate ore and fishery resources. Moreover, personnel stationed on the island cultivate vegetables and fruit and rear livestock. [...] From legal, economic, and geographic perspectives, Taiping Island (Itu Aba) indisputably qualifies as an 'island' according to the specifications of Article 121 of the United Nations Convention on the Law of the Sea

519 Statement of the Ministry of Foreign Affairs of the Socialist Republic of Viet Nam transmitted to the Arbitral Tribunal in the Proceedings between The Republic of the Philippines and The People's Republic of China, 22 January 2013, Annex 468, 44. 
(UNCLOS), and can sustain human habitation and economic life of its own; it is thus categorically not a 'rock'. The Roc government will firmly defend this fact. Any claims by other countries which aim to deny this fact will not impair the legal status of Taiping Island (Itu Aba) and its maritime rights based on UNCLOS. ${ }^{520}$

This statement suggests that Taiwan claims the maritime entitlements that flow from it classifying Itu Aba as a fully-fledged island under UnCLOs. The Tribunal did not invite Taiwan to participate in its proceedings, nor did it solicit Taiwan's views.

\subsubsection{Application of the Monetary Gold Principle with Respect to Taiwan}

The Tribunal's decision more than just "affects" Taiwan's putative legal rights and interests in relation to Itu Aba. Clearly, the Tribunal had to determine that Itu Aba is not a fully-fledged "island", and that no State can therefore claim EEZ or continental shelf rights with reference to it, before it could determine that Itu Aba is just a "rock". In other words, the Tribunal's determination that Itu Aba is not a fully-fledged island (as Taiwan claims) was "a prerequisite for a decision to be taken on" whether Itu Aba is a "rock". ${ }^{21}$ The only reasonable conclusion is that the Tribunal's decision on this point goes to the "very subject matter" of Taiwan's claim that Itu Aba is an island.

This begs the obvious question: could the Tribunal's - purported - disregard of Taiwan's legal interests with respect to Itu Aba be attributed to the disputed status of Taiwan as a subject of international law? Clearly (and correctly), the Tribunal did not view Taiwan as a separate "State" under international law, referring to it repeatedly as the "Taiwan Authority of China".522 The Tribunal

520 See the official publication of Taiwan's position on the website of the Ministry of Foreign Affairs at https://www.mofa.gov.uk.tw.en/News_Content.aspz?n=oE 7 B91A8FBEC4A9 $4 \& s=E D E B C A \circ 8 \mathrm{C}_{7} \mathrm{~F}_{51} \mathrm{C} 98$. Taiwan's claims go beyond Itu Aba: "Whether from the perspectives of history, geography, or international law, the Nansha (Spratly) Islands, Shisha (Paracel) Islands, Chungsha Islands (Macclesfield Bank), and Tungsha (Pratas) Islands, as well as their surrounding waters, are an inherent part of ROC territory and waters. As the ROC enjoys all rights to these island groups and their surrounding waters in accordance with international law, the ROC government does not recognize any claim to sovereignty over, or occupation of, these areas by other countries, irrespective of the reasons put forward or methods used for such claim or occupation."

521 Certain Phosphate Iands in Nauru, supra note 493, at para. 55 .

522 Award on the Merits, para. 139. The Roc claims that being called the "Taiwan Authority of China" is an "inappropriate designation [and] is demeaning to the status of the ROC as a sovereign state". Furthermore, we have seen (unconfirmed) reports that "Taiwan was keen to send representatives to observe the hearings held at The Hague [...]. Unfortunately, 
does not explicitly say that it did not apply the Monetary Gold principle because Taiwan is not a separate State under international law. In light of the Tribunal's silence on this point, the better reading of the Merits Award is that the Tribunal failed to consider whether it should apply the Monetary Gold principle at all with respect to Taiwan.

Irrespective of the Monetary Gold principle, in light of the Tribunal's "special responsibility" to satisfy itself that the claim was well-founded in fact and law, including as regards issues of jurisdiction, it would not have been improper for the Tribunal to have contacted Taiwan to request evidence (and perhaps even its views) as regards to the status of Itu Aba under Article 121(3) of UNCLOs. This is particularly the case given that the Tribunal reviewed and accepted a communication from the Chinese (Taiwan) Society of International Law, and given that Taiwanese authorities have occupied and administered TaiPing Dao (Itu Aba) for many years. Such an approach would have been a logical application of the Tribunal's power to "take all appropriate measures in order to establish the facts"

\subsection{The Tribunal Failed to State Adequate Reasons}

Article 10 of Annex VII to the Convention requires that the Award shall "state the reasons on which it is based". It is a fundamental principle of international law and a standard feature in contemporary international adjudication that any court or tribunal must give reasons for its decisions, a fortiori any decisions that are fundamental to its jurisdiction. ${ }^{523}$

due to the sensitive political and sovereignty issues involved, Taiwan's request to send a delegation was not granted by the Tribunal." See Taiwan's position on the website of the Ministry of Foreign Affairs at https://www.mofa.gov.tw/en/News_Content.aspx?n=1EAD DCFD4C6EC567\&s=5B5 A9134709EB875.

523 The I.C.J. has endorsed the requirement that an international judicial decision must be accompanied by a statement of reasons since its early judgments. For instance, in the Case Concerning the Arbitral Award made by the King of Spain on 23 December 1906 (Honduras v. Nicaragua), Nicaragua contested the validity of an arbitral award, inter alia, for it failing to state reasons. In examining Nicaragua's allegations, the Court acknowledged the requirement to provide reasons, albeit it ultimately found that the decision "deal[ $\mathrm{t}]$ in logical order and in some detail with all relevant consideration and (...) it contain[ed] ample reasoning and explanations in support of the conclusions arrived at by the arbitrator"; Judgment, 18 November 196o, I.C.J. Reports 196 at 2016. See also Article 56(1), Statute of the International Court of Justice, "The judgment shall state the reasons on which it is based"; Article 29, Model Rules on Arbitral Procedure, International Law Commission, "The award shall, in respect of every point on which it rules, state the reasons on which it is based"; Article 32(2), International Chamber of Commerce, Arbitration Rules, 2017, "The award shall state the reasons upon which it is based"; Article 48(3) ICsID Convention, "The award shall deal with every question submitted to the Tribunal, and shall state the 
In the investor-State dispute resolution context, an ICSID ad hoc committee has explained that statement of reasons "does not mean just any reasons, purely formal or apparent, but rather reasons having some substance, allowing the reader to follow the arbitral tribunal's reasoning, on facts and on law". ${ }^{24}$ The committee further explained that "apparently relevant" reasoning would not suffice as reasons are required to be "sufficiently relevant", that is, "reasonably sustainable and capable of providing a basis for the decision".525

In our view, the Tribunal arguably failed to provide in its Merits Award "sufficiently relevant" reasons for its conclusions as regards the status of the Secondary High Tide Features under Article 121 (i.e., Amboyna Cay, Flat Island, Loaita Island, Namyit Island, Nanshan Island, Sand Cay, Sin Cowe Island and Swallow Reef).

Before it turned to classifying the Secondary High Tide Features, the Tribunal set out factors that it would consider for the purposes of classifying the features in the South China Sea. The Tribunal observed, in particular, that "the capacity of a feature to sustain human habitation or an economic life of its own must be assessed on a case-by-case basis" 526 and that the "negotiating history clearly demonstrates the difficulty in setting, in the abstract, brightline rules for all cases".527 The Tribunal also made the important observation that features could not be categorised as islands or rocks by reference to their "size" alone:

The Tribunal considers that the travaux make clear that - although size may correlate to the availability of water, food, living space, and resources for an economic life - size cannot be dispositive of a feature's status as a fully entitled island or rock and is not, on its own, a relevant factor. As noted by the International Court of Justice in Territorial and Maritime Dispute (Nicaragua v. Colombia), 'international law does not prescribe any minimum size which a feature must possess in order to be considered an island. ${ }^{528}$

reasons upon which it is based"; Article 47(i), ICSID Arbitration Rules, "The award shall be in writing and shall contain: (...) (i) the decision of the Tribunal on every question submitted to it, together with the reasons upon which the decision is based".

524 Klöckner Industrie-Anlagen GmbH and others v. United Republic of Cameroon and Société Camerounaise des Engrais, ICSID Case No. ARB/81/2, Decision on Annulment, 3 May 1985, para. 119 .

525 Id. at para. 120.

526 Award, supra note 1, at para. 546.

527 Id. at para. 537 .

$528 \quad I d$. at para. 538 . 
Having made these observations, the Tribunal turned to classifying the Secondary High Time Features. The Tribunal determined that:

Other high-tide features claimed by China atop coral reefs in the Spratly Islands are smaller in size than the above-described features, with surface areas of less than 0.14 square kilometres, but present similar characteristics. The Tribunal has examined Amboyna Cay, Flat Island, Loaita Island, Namyit Island, Nanshan Island, Sand Cay, Sin Cowe Island, and Swallow Reef for evidence of human habitation or economic life, but does not consider it necessary to discuss them individually. The Tribunal considers that if the six largest features described above are all to be classified as rocks for purposes of Article 121(3) of the Convention, the same conclusion would also hold true for all other high-tide features in the Spratly Islands. ${ }^{529}$

It is well-established that a tribunal "fails to give reasons" when the reader cannot:

follow the reasoning of the Tribunal on points of fact and law [...] the requirement to state reasons is satisfied as long as the award enables one to follow how the Tribunal proceeds from Point A to Point B and eventually to its conclusion, even if it made an error of fact or law. 530

The Tribunal arguably failed to state reasons for its conclusion that the Secondary High Tide Features. It is not possible to follow the Tribunal's reasoning in at least two respects: (1) by "not consider[ing] it necessary to discuss them individually", the Tribunal did precisely the opposite of what it said it would do i.e., it did not classify the Secondary High Tide Features on a "caseby-case" basis; and (2) the Tribunal drew a "bright-line rule for all cases" on the basis of size alone. Contrary to its conclusions on the relevant aspects of the test under UNCLOS, the Tribunal took a shortcut determining that, merely because the Secondary High Tide Features were smaller than the six largest features (which the Tribunal deemed were rocks), it would "hold true" that all other hide-tide features in the Spratly Islands would also be "rocks". The contradictions in the Tribunal's approach are, in any event, manifest with respect to its findings as regards the Secondary High Tide Features.

529 Id. at para. 407.

530 Maritime International Nominees Establishment v. Republic of Guinea, ICsid Case No. ARB $/ 84 / 4$, Decision of the ad hoc committee, 6 January 1988, paras. 5.08-o9. 


\section{$6 \quad$ ANNEX 1}

TABLE 1 Small features mutually recognised as being fully entitled under Article 121(2) of UNCLOS

\begin{tabular}{|c|c|c|c|c|c|c|}
\hline Feature & Location & Size (Area) & Population & $\begin{array}{l}\text { Presence of } \\
\text { potable water }\end{array}$ & $\begin{array}{l}\text { Vegetation } \\
\text { and biology }\end{array}$ & $\begin{array}{l}\text { Soil and } \\
\text { agricultural } \\
\text { potential }\end{array}$ \\
\hline $\begin{array}{l}\text { Itu Aba } \\
\text { (Taiping } \\
\text { Dao/Ligaw } \\
\text { Island) }\end{array}$ & $\begin{array}{l}\text { South } \\
\text { China Sea }\end{array}$ & $0.43 \mathrm{~km}^{2}$ & $\begin{array}{l}\text { Approx. 6oo } \\
\text { military and } \\
\text { technical } \\
\text { personnel } \\
\text { Multiple } \\
\text { buildings, } \\
\text { lighthouse, } \\
\text { and runway }\end{array}$ & $\begin{array}{l}\text { Yes } \\
\text { Fresh/mix } \\
\text { water wells }\end{array}$ & $\begin{array}{l}\text { Yes } \\
\text { Heavily forested }\end{array}$ & $\begin{array}{l}\text { Yes } \\
\text { Limited cultivation }\end{array}$ \\
\hline $\begin{array}{l}\text { Isla Aves } \\
\text { (Birds } \\
\text { Island) }\end{array}$ & $\begin{array}{l}\text { Caribbean } \\
\text { Sea }\end{array}$ & $\begin{array}{l}0.032 \mathrm{~km}^{2} \\
\text { Storm surges may } \\
\text { submerge the entire } \\
\text { islet, changing its } \\
\text { size and reshaping } \\
\text { its topography } \\
\text { During hurricanes, } \\
\text { the island can } \\
\text { be completely } \\
\text { submerged }\end{array}$ & $\begin{array}{l}\text { Uninhabited } \\
\text { Permanently } \\
\text { staffed } \\
\text { scientific } \\
\text { station } \\
\text { and naval } \\
\text { contingent }\end{array}$ & No & $\begin{array}{l}\text { Nesting site } \\
\text { to green sea } \\
\text { turtles and } \\
\text { birds }\end{array}$ & $\begin{array}{l}\text { No } \\
\text { Mostly sandy and } \\
\text { scarce vegetation } \\
\text { (scrubby bushes) }\end{array}$ \\
\hline
\end{tabular}

$\begin{array}{rllll}\text { Clipperton Pacific } & 6 \mathrm{~km}^{2} & \text { Uninhabited } & \text { Yes } & \text { Scattered } \\ \text { Ocean } & & \text { since } 1945 & \text { Stagnant } & \text { grasses and } \\ & & \text { Visited by } & \text { Fresh-water } & \text { coconut palms } \\ & \text { French Patrol lagoon } & \\ & \text { and scientific } \\ & \text { researchers } & \end{array}$




$\begin{array}{lllll}\begin{array}{l}\text { Presence of } \\ \text { fishermen }\end{array} & \begin{array}{l}\text { Commercial } \\ \text { operations }\end{array} & \begin{array}{l}\text { Effective } \\ \text { control }\end{array} & \begin{array}{l}\text { Maritime } \\ \text { claims }\end{array} & \text { Legal/Political developments } \\ \end{array}$

\begin{tabular}{|c|c|c|c|c|}
\hline $\begin{array}{l}\text { Yes } \\
\text { Small groups }\end{array}$ & $\begin{array}{l}\text { Yes } \\
\text { Scarce } \\
\text { mining and } \\
\text { port facilities }\end{array}$ & Taiwan & EEZ and CS & $\begin{array}{l}\text { The disputing States are China (including Taiwan), } \\
\text { Philippines and Vietnam. }\end{array}$ \\
\hline
\end{tabular}

Yes No

Fishing is the main economic activity

$\begin{array}{llll}\text { Yes } & \text { Mining } & \text { France } & \text { EEZ, CS } \\ \text { Tuna fishing } & \text { settlement } \\ & \text { and Guano } \\ \text { deposits } & & \\ & & \end{array}$

Venezuela TS, EEZ, CS

An arbitration Award of 1865, by the Queen of Spain, established the Venezuelan sovereignty over the island. Venezuela claims it as an island. It has been given full effect in various delimitation agreements, including United States-Venezuela (1978), the Netherlands (Antilles)-Venezuela (1978) and Venezuela-France Agreement (1980).

On 26 July 1978, Venezuela enacted legislation establishing an EEZ along its mainland coasts and islands.

Dominica has traditionally claimed sovereignty as it lies within its EEz. Nevertheless, it dropped its claims in 2006, soon after joining the ALBA alliance.

Venezuela's position on maritime claims is complex as it is not signatory of UNCLOS. As such, its claims to an EEZ around Isla Aves have not been formalised.

Currently a Minor Oversea Territory of France.

Mexico and France signed a compromise in 19o9, agreeing to submit the dispute over Clipperton to arbitration and appointed King Victor Emanuel of Italy as the sole arbitrator. In 1931, the King rendered an arbitral award declaring French sovereignty over the island.

After some fishermen incidents, Mexico claimed the feature should be qualified as a rock in the sense of Article 121(3) of UNCLOS. Consequently, in 2017, Mexico and France concluded an agreement on fishing activities of Mexican vessels within 200 nautical miles surrounding Clipperton, which interestingly avoided the expression EEZ.

In 2010, France deposited a list of geographical coordinates of points defining the outer limits of the EEZ and CS of the island. 
TABLE 1 Small features mutually recognised as being fully entitled under Article 121(2) of UNCLOS (cont.)

\begin{tabular}{|c|c|c|c|c|c|c|}
\hline Feature & Location & Size (Area) & Population & $\begin{array}{l}\text { Presence of } \\
\text { potable water }\end{array}$ & $\begin{array}{l}\text { Vegetation } \\
\text { and biology }\end{array}$ & $\begin{array}{l}\text { Soil and } \\
\text { agricultural } \\
\text { potential }\end{array}$ \\
\hline Jan Mayen & $\begin{array}{l}\text { Arctic } \\
\text { Ocean }\end{array}$ & $373 \mathrm{~km}^{2}$ & $\begin{array}{l}\text { No settled } \\
\text { population } \\
\text { Military, } \\
\text { scientific } \\
\text { and radio } \\
\text { personnel. } \\
\text { Presence } \\
\text { landing field }\end{array}$ & No & $\begin{array}{l}\text { Important } \\
\text { bird area }\end{array}$ & Volcanic island \\
\hline
\end{tabular}

TABLE 2 Small features unilaterally claimed as fully-entitled islands under Article 121(2) of UNCLOS

\begin{tabular}{|c|c|c|c|c|c|c|}
\hline Feature & Location & Size (Area) & Population & $\begin{array}{l}\text { Presence } \\
\text { of potable } \\
\text { water }\end{array}$ & $\begin{array}{l}\text { Vegetation } \\
\text { and biology }\end{array}$ & $\begin{array}{l}\text { Soil and } \\
\text { agricultural } \\
\text { potential }\end{array}$ \\
\hline $\begin{array}{l}\text { Itu Aba } \\
\text { (Taiping Dao/ } \\
\text { Ligaw Island) }\end{array}$ & South China Sea & $0.43 \mathrm{~km}^{2}$ & $\begin{array}{l}\text { Approx. } 6 \text { oo } \\
\text { military and } \\
\text { technical personnel } \\
\text { Multiple buildings, } \\
\text { lighthouse, and } \\
\text { runway }\end{array}$ & $\begin{array}{l}\text { Yes } \\
\text { Fresh/mix } \\
\text { water wells }\end{array}$ & $\begin{array}{l}\text { Yes } \\
\text { Heavily } \\
\text { forested }\end{array}$ & $\begin{array}{l}\text { Yes } \\
\text { Limited } \\
\text { cultivation }\end{array}$ \\
\hline
\end{tabular}




$\begin{array}{lllll}\begin{array}{l}\text { Presence of } \\ \text { fishermen }\end{array} & \begin{array}{l}\text { Commercial } \\ \text { operations }\end{array} & \begin{array}{l}\text { Effective } \\ \text { control }\end{array} & \begin{array}{l}\text { Maritime } \\ \text { claims }\end{array} & \text { Legal/Political developments } \\ \end{array}$

\begin{tabular}{llll}
\hline Yes $\quad$ Yes & Norway & TS, EEZ, CS \\
& $\begin{array}{l}\text { Whaling } \\
\text { station }\end{array}$
\end{tabular}
In 1976, The Norwegian Parliament enacted legislation establishing 200-mile around its coasts. Then, by Royal Decree taking effect on 29 May 1980, the Norwegian Government established a 2oo-mile fishery zone specifically around Jan Mayen. The Decree provided that the fishery zone should not extend beyond the median line in relation to Greenland.
On 28 May 1980, Iceland and Norway concluded an Agreement concerning fishery and continental shelf. In the agreement, the Parties agreed to refer outer continental shelf claims to a Conciliation Commission. In referring to the legal status of Jan Mayen, the Commission concluded that Jan Mayen must be considered as an island, thus entitled to a territorial sea, an economic zone and a continental shelf. In its Judgment of 14 June 1993 concerning the Maritime Delimitation in the area between Greenland and Jan Mayen, the ICJ fixed a delimitation line for both the continental shelf and the fishery zones of Denmark and Norway.

\begin{tabular}{lllll}
\hline $\begin{array}{l}\text { Presence of } \\
\text { fishermen }\end{array}$ & $\begin{array}{l}\text { Commercial } \\
\text { operations }\end{array}$ & $\begin{array}{l}\text { Effective } \\
\text { control }\end{array}$ & $\begin{array}{l}\text { Maritime } \\
\text { claims }\end{array}$ & Legal/Political developments \\
& & &
\end{tabular}

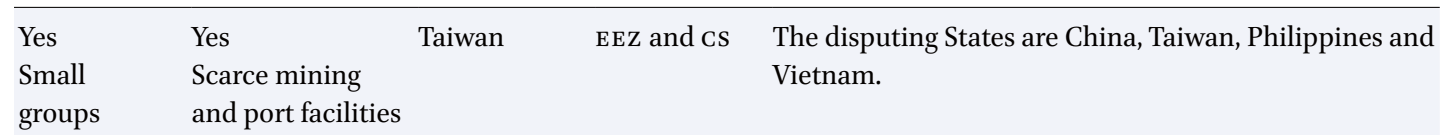


TABLE 2 Small features unilaterally claimed as fully-entitled islands under Article 121(2) of UNCLOS (cont.)

\begin{tabular}{|c|c|c|c|c|c|c|}
\hline Feature & Location & Size (Area) & Population & $\begin{array}{l}\text { Presence } \\
\text { of potable } \\
\text { water }\end{array}$ & $\begin{array}{l}\text { Vegetation } \\
\text { and biology }\end{array}$ & $\begin{array}{l}\text { Soil and } \\
\text { agricultural } \\
\text { potential }\end{array}$ \\
\hline Tromelin & Indian Ocean & o.8o km² & $\begin{array}{l}\text { Uninhabited } \\
\text { No continuous } \\
\text { human presence } \\
\text { There is no harbour } \\
\text { nor anchorages on } \\
\text { the island, but a } \\
\text { 1,200-metre airstrip }\end{array}$ & No & $\begin{array}{l}\text { Limited } \\
\text { Significant } \\
\text { numbers of } \\
\text { seabirds }\end{array}$ & No \\
\hline
\end{tabular}

$\begin{array}{lllllll}\begin{array}{l}\text { Bassas da } \\ \text { India }\end{array} & \begin{array}{l}\text { Mozambique } \\ \text { Channel }\end{array} & 0.2 \mathrm{~km}^{2} & \text { Uninhabited } & \text { No } & \text { No } \\ \\ \text { Juan de Nova } & \begin{array}{l}\text { Mozambique } \\ \text { Channel }\end{array} & 4.4 \mathrm{~km}^{2} & \text { Uninhabited } & \text { No } & \begin{array}{l}\text { Nontified as No } \\ \text { an important } \\ \text { Bird Area }\end{array}\end{array}$




$\begin{array}{lllll}\begin{array}{l}\text { Presence of } \\ \text { fishermen }\end{array} & \begin{array}{l}\text { Commercial } \\ \text { operations }\end{array} & \begin{array}{l}\text { Effective } \\ \text { control }\end{array} & \begin{array}{l}\text { Maritime } \\ \text { claims }\end{array} & \text { Legal/Political developments } \\ \end{array}$

No No France

TS, EEZ by

France.

Basepoint in

measuring

the maritime

areas by

Mauritius

No

$\begin{array}{ll}\text { No } & \begin{array}{l}\text { France } \\ \text { since } 1897\end{array}\end{array} \quad$ TS, EEZ

since 1897

Guano deposits

were exploited

from the start of

the $x x$ century

until 1970

France TS, EEZ

since 1972
In 1968, France placed it under the administration of a commissioner residing on the island of Réunion.

In 1978, France issued the Decree No. 78-146 (Article 1, pp. 16-21) unilaterally establishing sovereignty and an EEZ of 188 nautical miles from the outer limit of the French Republic off the coasts the scattered islands, subject to delimitation agreements with neighboring countries.

In contrast, the Constitution of Mauritius included Tromelin as a part of the Mauritian territory. Also, in 2008, Mauritius deposited with the UN Department for Ocean Affairs and the Law of the Sea, the charts and lists of geographical coordinates of basepoints and baselines for the maritime zones, including Tromelin, representing the basepoints and defining the baselines from which the maritime zones of Mauritius shall be measured (see p. 1).

The controversy over Tromelin has led to the postponing of the ratification by the French Parliament of a Framework Agreement entered into by France and Mauritius in June 2010, providing for joint economic, scientific and environmental management (cogestion) of the island and of surrounding maritime areas.

In 1968, France placed it under the administration of a commissioner residing on the island of Réunion.

In 1978, France issued the Decree No. 78-146 (Article 1, pp. 16-21) establishing unilaterally sovereignty and an EEZ of 188 nautical miles from the outer limit of the French Republic off the coasts the scattered islands, subject to delimitation agreements with neighbouring countries.

In 1968, France placed it under the administration of a commissioner residing on the island of Réunion. In 1978, France issued the Decree No. 78-146 (Article 1, pp. 16-21) establishing unilaterally sovereignty and an EEZ of 188 nautical miles from the outer limit of the French Republic off the coasts the scattered islands, subject to delimitation agreements with neighboring countries. 
TABLE 2 Small features unilaterally claimed as fully-entitled islands under Article 121(2) of UNCLOS (cont.)

\begin{tabular}{|c|c|c|c|c|c|c|}
\hline Feature & Location & Size (Area) & Population & $\begin{array}{l}\text { Presence } \\
\text { of potable } \\
\text { water }\end{array}$ & $\begin{array}{l}\text { Vegetation } \\
\text { and biology }\end{array}$ & $\begin{array}{l}\text { Soil and } \\
\text { agricultural } \\
\text { potential }\end{array}$ \\
\hline $\begin{array}{l}\text { Glorioso } \\
\text { Islands }\end{array}$ & $\begin{array}{l}\text { Indian Ocean } \\
\text { Southern Africa, } \\
\text { Northwest of } \\
\text { Madagascar) }\end{array}$ & $\begin{array}{l}5 \mathrm{~km}^{2} \\
\text { Includes: } \\
\text { Ile } \\
\text { Glorieuse, Ile } \\
\text { du Lys, Verte } \\
\text { Rocks, Wreck } \\
\text { Rock, and } \\
\text { South Rock }\end{array}$ & $\begin{array}{l}\text { Small Military and } \\
\text { scientific (weather } \\
\text { station) personnel }\end{array}$ & No & $\begin{array}{l}\text { Yes } \\
\text { Guano and } \\
\text { coconuts } \\
\text { (Glorieuse, Ile } \\
\text { du Lys, Verte) }\end{array}$ & No \\
\hline $\begin{array}{l}\text { Victoria } \\
\text { Island }\end{array}$ & Arctic Ocean & $10.8 \mathrm{Km}^{2}$ & Uninhabited & No & No & $\begin{array}{l}\text { Almost entirely } \\
\text { covered by an } \\
\text { ice cap }\end{array}$ \\
\hline $\begin{array}{l}\text { Henrietta } \\
\text { and } \\
\text { Jeannette }\end{array}$ & Arctic Ocean & $12 \mathrm{Km}^{2}$ & $\begin{array}{l}\text { Uninhabited } \\
\text { A polar station } \\
\text { was established } \\
\text { in } 1937 \text { but closed } \\
\text { in } 1963\end{array}$ & No & No & $\begin{array}{l}\text { Almost entirely } \\
\text { covered by an } \\
\text { ice cap } \\
\text { Composed of } \\
\text { Volcanic rock }\end{array}$ \\
\hline $\begin{array}{l}\text { Europa } \\
\text { Island }\end{array}$ & $\begin{array}{l}\text { Mozambique } \\
\text { Channel }\end{array}$ & $28 \mathrm{Km}^{2}$ & $\begin{array}{l}\text { Small military and } \\
\text { scientific (weather } \\
\text { station) personnel }\end{array}$ & No & $\begin{array}{l}\text { Abundance } \\
\text { of wood } \\
\text { and wildlife } \\
\text { sanctuary }\end{array}$ & No \\
\hline $\begin{array}{l}\text { Johnston Atoll } \\
\text { (Johnston } \\
\text { Island, Sand } \\
\text { Island, Akau } \\
\text { and Hikina) }\end{array}$ & $\begin{array}{l}\text { North Pacific } \\
\text { Ocean }\end{array}$ & $2.63 \mathrm{~km}^{2}$ & $\begin{array}{l}\text { Uninhabited } \\
\text { In previous years, } \\
\text { average of 1,100 US } \\
\text { military and } \\
\text { contractors present; } \\
\text { all had left by } 2005\end{array}$ & No & $\begin{array}{l}\text { Yes } \\
\text { Terrestrial } \\
\text { and aquatic } \\
\text { wildlife }\end{array}$ & $\begin{array}{l}\text { Yes } \\
\text { Limited } \\
\text { cultivation }\end{array}$ \\
\hline Trindade & $\begin{array}{l}\text { Southern } \\
\text { Atlantic Ocean }\end{array}$ & $10.1 \mathrm{~km}^{2}$ & $\begin{array}{l}32 \text { Brazilian Navy } \\
\text { personnel }\end{array}$ & $\begin{array}{l}\text { Limited } \\
\text { Natural } \\
\text { springs } \\
\text { have largely } \\
\text { dried up }\end{array}$ & Yes & No \\
\hline
\end{tabular}




$\begin{array}{lllll}\begin{array}{l}\text { Presence of } \\ \text { fishermen }\end{array} & \begin{array}{l}\text { Commercial } \\ \text { operations }\end{array} & \begin{array}{l}\text { Effective } \\ \text { control }\end{array} & \begin{array}{l}\text { Maritime } \\ \text { claims }\end{array} & \text { Legal/Political developments } \\ \end{array}$

\begin{tabular}{|c|c|c|c|c|}
\hline No & $\begin{array}{l}\text { No economic } \\
\text { activity }\end{array}$ & $\begin{array}{l}\text { France since } \\
1892\end{array}$ & TS and EEZ & $\begin{array}{l}\text { In } 1978 \text {, France issued the Decree No. } 78-146 \text { (see } \\
\text { Article 1, pp. 16-21) establishing unilaterally sovereignty } \\
\text { and an EEZ of } 188 \text { nautical miles from the outer limit of } \\
\text { the French Republic off the coasts the scattered islands, } \\
\text { subject to delimitation agreements with neighboring } \\
\text { countries. }\end{array}$ \\
\hline No & No & Russia & CS & $\begin{array}{l}\text { Administered as part of Franz Josef Land and belongs } \\
\text { to the Arkhangelsk Oblast administrative division of } \\
\text { the Russian Federation. }\end{array}$ \\
\hline No & No & Russia & CS & $\begin{array}{l}\text { Not included in the US purchased of Alaska from } \\
\text { Russia in } 1867 \text {, neither have them been claimed by the } \\
\text { US. }\end{array}$ \\
\hline No & No & France & EEZ & $\begin{array}{l}\text { In } 1978 \text {, France issued the Decree No. } 78-146 \text { (Article } 1 \text {, } \\
\text { pp. } 16-21 \text { ) establishing unilaterally sovereignty and an } \\
\text { EEZ of } 188 \text { nautical miles from the outer limit of the } \\
\text { French Republic off the coasts the scattered islands, } \\
\text { subject to delimitation agreements with neighbouring } \\
\text { countries. }\end{array}$ \\
\hline
\end{tabular}

Previously used (since 1858)

for mining and

nuclear testing

Annexed by the US and the Kingdom of Hawaii in 1858 It was designated as a wildlife refuge in 1926, and then taken over by the US Navy in 1934, and then the US Air Force in 1948.

The atoll was used for high-altitude nuclear tests in the 195 os and 196os and was used as a storage and disposal site for chemical weapons until the 2000 .

The weapons facility on the atoll was closed in May 2005 .

Brazil (since [EEZ and Ts]

1822) 
TABLE 2 Small features unilaterally claimed as fully-entitled islands under Article 121(2) of UNCLOS (cont.)

\begin{tabular}{|c|c|c|c|c|c|c|}
\hline Feature & Location & Size (Area) & Population & $\begin{array}{l}\text { Presence } \\
\text { of potable } \\
\text { water }\end{array}$ & $\begin{array}{l}\text { Vegetation } \\
\text { and biology }\end{array}$ & $\begin{array}{l}\text { Soil and } \\
\text { agricultural } \\
\text { potential }\end{array}$ \\
\hline $\begin{array}{l}\text { Heard Island } \\
\text { and } \\
\text { McDonald } \\
\text { Islands }\end{array}$ & Indian Ocean & $412 \mathrm{~km}^{2}$ & Uninhabited & No & No & No \\
\hline $\begin{array}{l}\text { Howland } \\
\text { Island }\end{array}$ & $\begin{array}{l}\text { North Pacific } \\
\text { Ocean }\end{array}$ & $1.6 \mathrm{~km}^{2}$ & Uninhabited & No & Yes & {$[\mathrm{No}]$} \\
\hline Jarvis Island & $\begin{array}{l}\text { South Pacific } \\
\text { Ocean }\end{array}$ & $4.5 \mathrm{~km}^{2}$ & Uninhabited & No & Yes & {$[\mathrm{No}]$} \\
\hline Wake Island & $\begin{array}{l}\text { North Pacific } \\
\text { Ocean }\end{array}$ & $6.5 \mathrm{~km}^{2}$ & $\begin{array}{l}\text { No indigenous } \\
\text { inhabitants } \\
\text { (there are } \\
\text { approximately 10o } \\
\text { military personnel } \\
\text { and civilian } \\
\text { contractors) }\end{array}$ & Yes & No & No \\
\hline
\end{tabular}




$\begin{array}{lllll}\begin{array}{l}\text { Presence of } \\ \text { fishermen }\end{array} & \begin{array}{l}\text { Commercial } \\ \text { operations }\end{array} & \begin{array}{l}\text { Effective } \\ \text { control }\end{array} & \begin{array}{l}\text { Maritime } \\ \text { claims }\end{array} & \text { Legal/Political developments } \\ & & & \end{array}$

\begin{tabular}{|c|c|c|c|c|}
\hline No & $\begin{array}{l}\text { No } \\
\text { Limited fishing } \\
\text { in surrounding } \\
\text { waters }\end{array}$ & $\begin{array}{l}\text { Australia } \\
\text { (since 1947) }\end{array}$ & EEZ and TS & $\begin{array}{l}\text { The UK transferred these islands to Australia in } 1947 . \\
\text { There are no disputes regarding the islands. }\end{array}$ \\
\hline No & No & $\begin{array}{l}\text { United States } \\
\text { (since 1857) }\end{array}$ & EEZ and TS & \\
\hline No & No & $\begin{array}{l}\text { United States } \\
\text { (since 1935) }\end{array}$ & EEZ and TS & $\begin{array}{l}\text { Discovered by the British in } 1821 \text {. Annexed by the US } \\
\text { in } 185^{8} \text { but abandoned in } 1879 \text {. The UK then annexed } \\
\text { the island in } 1889 \text {. The US occupied and reclaimed the } \\
\text { island in } 1935 \text {. } \\
\text { The island was abandoned after World War II. }\end{array}$ \\
\hline No & $\begin{array}{l}\text { Yes } \\
\text { Provides services } \\
\text { to military } \\
\text { personnel and } \\
\text { contractors. } \\
\text { All foods and } \\
\text { manufactured } \\
\text { goods are } \\
\text { imported }\end{array}$ & United States & EEZ and TS & $\begin{array}{l}\text { Annexed in } 1899 \text { for a cable station. Air and naval base } \\
\text { constructed in 1940. In 1941, the island was captured by } \\
\text { the Japanese and held until the end of World War II. } \\
\text { Since 1974, the island's airstrip has been used by the } \\
\text { US military. }\end{array}$ \\
\hline
\end{tabular}

